\title{
3. CENOZOIC RADIOLARIA FROM THE ARABIAN SEA, DSDP LEG 23
}

\author{
Catherine Nigrini, 17 Highland Avenue, Lexington, Massachusetts,USA
}

\section{INTRODUCTION}

Three of the DSDP Leg 23 sites yielded large numbers of radiolarians; they are:

Site $219-9^{\circ} 01.75^{\prime} \mathrm{N}, 72^{\circ} 52.67^{\prime} \mathrm{E}$; water depth 1764 meters

Site $220-6^{\circ} 30.97^{\prime} \mathrm{N}, 70^{\circ} 59.02^{\prime} \mathrm{E}$; water depth 4036 meters

Site $223-18^{\circ} 44.98^{\prime} \mathrm{N}, 60^{\circ} 07.78^{\prime} \mathrm{E}$; water depth 3633 meters

At all other sites they are sparse or absent. Only Cenozoic forms were recovered. Site 219 contains a sequence ranging in age from the Thyrsocyrtis bromia Zone (Early Oligocene) to the Early Eocene; Site 220 contains material ranging in age from the Calocycletta virginis Zone (Late Oligocene according to nannofossil data) to the Early Eocene; and Site 223 contains Quaternary to Middle Miocene (Cannartus (?) petterssoni Zone) radiolarians.

\section{RADIOLARIAN ZONATION}

The presentation of material and general format used herein follows that used by Riedel and Sanfilippo (1971). However, the radiolarian zonation presented herein differs from that of Riedel and Sanfilippo $(1970,1971)$ and Moore (1971) in several respects because a number of critical species are absent to very rare in the Arabian Sea material examined. At Site 223, Pterocanium prismatium is practically absent, and it was necessary to approximate the position of the $P$. prismatium Zone using other species. According to the nannofossil data (see Boudreaux, J.E., this volume) those samples containing a radiolarian assemblage belonging to the Calocycletta virginis Zone (Site 220) are Upper Oligocene. Previous workers have always shown the $C$. virginis Zone to lie entirely within the Lower Miocene. Also at Site 220 Lychnocanoma elongata (Vinassa) (formerly Lychnocanium bipes Riedel, see Sanfilippo et al., in press), Dorcadospyris papilio and Theocyrtis annosa are absent, making recognition of their respective zones impossible. Theocyrtis tuberosa is very rare at both Sites 219 and 220 , but since the base of the $T$. tuberosa Zone is defined by the first appearance of Lithocyclia angustum, and the top is coincident with the base of the Dorcadospyris ateuchus Zone (Riedel and Sanfilippo, 1971), it was possible to place its zonal boundaries. At Site 219, Thyrsocyrtis tetracantha does not range lower than Thyrsocyrtis bromia and so the only recognizable Late Eocene zone is the T. bromia Zone (as in Sanfilippo and Riedel, 1973). Podocyrtis goetheana is absent from, and Podocyrtis chalara is very rare in Leg 23 material and, hence, neither of these zones could be recognized. Podocyrtis ampla ampla is practically absent, but at about the level where one would expect to find it, there is a closely related form, Podocyrtis ampla fasciolata, which is described herein. The first appearance of $P$. ampla fasciolata is used to define the base of the $P$. ampla fasiolata Zone; the top of the zone is coincident with the base of the Podocyrtis mitra Zone. This zone may be quite local and does not replace what should now be called the Podocyrtis ampla ampla Zone in other oceanographic regions.

\section{RADIOLARIANS AT EACH SITE}

In this section, the radiolarian findings for each site are summarized. For Sites 219, 220, and 223, information on specific occurrences are tabulated. In these tables, A, C, F, and $\mathrm{R}$ (abundant, common, few and rare, respectively) indicate the abundance of a particular species. A positive $(+)$ sign is used when one or two specimens were found on a single strewn-slide. A dash(-) indicates absence of a species in a sample in which it was searched for. Condition of preservation is noted by $\mathrm{P}, \mathrm{M}$, and $\mathrm{G}$ for poor, moderate, and good, respectively. Samples are designated by core and section number and sampled interval (in centimeters).

\section{Site 219}

Rare, often fragmented, specimens of Radiolaria are present in the core catcher samples of Cores 1 through 10 . No age assignment based on Radiolaria was possible in this interval. Radiolaria are absent from Cores 11 through Core 16 , Section $5,12-14 \mathrm{~cm}$. At level 16-5, $28-30 \mathrm{~cm}$ appears a rich radiolarian fauna belonging to the Thyrsocyrtis bromia Zone (Table 1). There is no obvious megascopic change in lithology between the radiolarian and nonradiolarian parts of the core. The base of the $T$. bromia Zone lies between Sections 4 and 5 of Core 18. Between Cores 18 , Section 5 and Core 19, Section 5, the radiolarian fauna is characteristic of the Podocyrtic mitra Zone. Below the $P$. mitra Zone lies a new zone, the Podocyrtis ampla fasciolata Zone, which approximates stratigraphically the Podocyrtis ampla ampla Zone of Riedel and Sanfilippo (1970). P. ampla ampla is absent from the present material. Between the $P$. mitra and $P$. ampla fasciolata zones there is an apparent faunal gap owing to the formation of chert in Core 19, Section 6. Radiolaria are common and well preserved in Core 19, Section 5 and 19, CC, but are almost absent from Core 19, Section 6. The Thyrsocyrtis triacantha Zone extends from Core 20, Section 6 to 21, CC. Core 21 bottomed in chert. Below the chert layer, in the core catcher sample of Core 24 , a sparse and poorly preserved assemblage appears to belong to the Theocampe mongolfieri Zone. Radiolaria were not found in subsequent Site 219 cores.

\section{Site 220}

At Site 220, Radiolaria are rare or absent in Cores 1 through 5 (down to 45 meters); see Table 2 . The hole was then drilled to 93 meters, where a good radiolarian 
TABLE 1

Radiolarians from Site 219

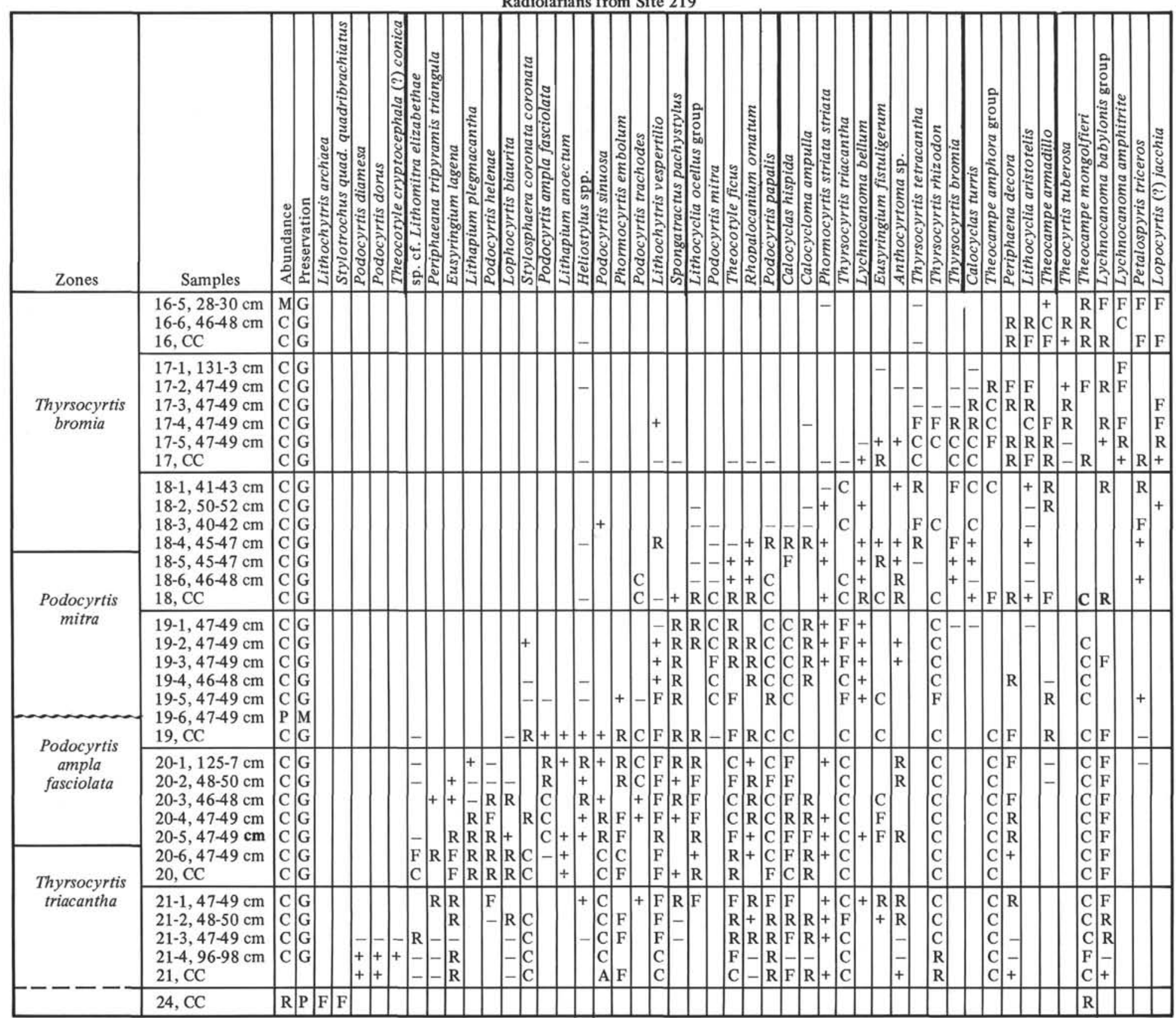

Note: See text for an explanation of symbols. 
TABLE 2

Radiolarians from Site $\mathbf{2 2 0}$

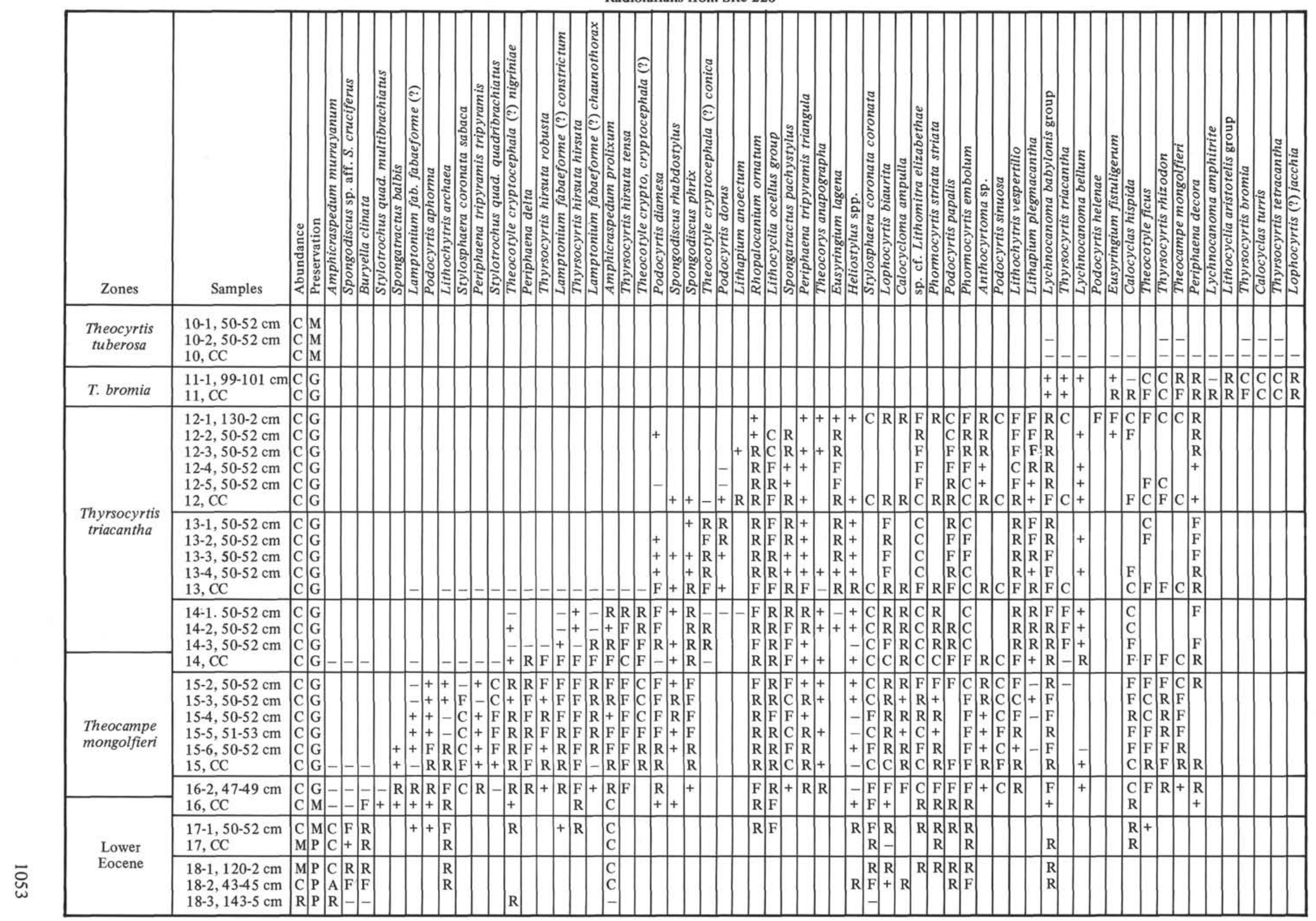


TABLE 2 - continued

\begin{tabular}{|c|c|c|c|c|c|c|c|c|c|c|c|c|c|c|}
\hline Zones & Samples & 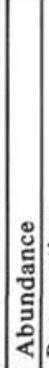 & 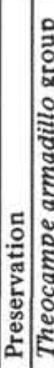 & 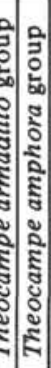 & 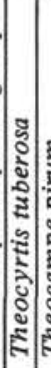 & 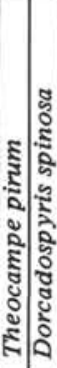 & 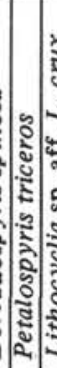 & 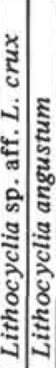 & : & 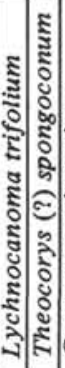 & 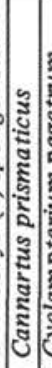 & 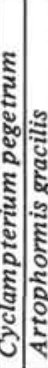 & 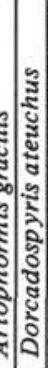 & 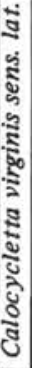 \\
\hline $\begin{array}{l}\text { Calocycletta } \\
\text { virginis }\end{array}$ & $\begin{array}{l}6-1,51-53 \mathrm{~cm} \\
6-2,50-52 \mathrm{~cm} \\
6-3,50-52 \mathrm{~cm} \\
6-5,51-53 \mathrm{~cm} \\
6-6,51-53 \mathrm{~cm} \\
6, \mathrm{CC}\end{array}$ & \begin{tabular}{l|}
$\mathrm{F}$ \\
$\mathrm{F}$ \\
$\mathrm{C}$ \\
$\mathrm{C}$ \\
$\mathrm{C}$ \\
$\mathrm{C}$
\end{tabular} & \begin{tabular}{l|}
$\mathrm{M}$ \\
$\mathrm{M}$ \\
$\mathrm{G}$ \\
$\mathrm{G}$ \\
$\mathrm{M}$ \\
$\mathrm{M}$
\end{tabular} & & & & & & & + & $\begin{array}{lll} & \\
+ & 1 \\
+ \\
+\end{array}$ & \begin{tabular}{l|l}
$\mathrm{R}$ & $\mathrm{F}$ \\
$\mathrm{F}$ \\
$\mathrm{F}$ \\
$\mathrm{R}$ \\
$\mathrm{F}$
\end{tabular} & $\begin{array}{l}F \\
F \\
C \\
F \\
F \\
F\end{array}$ & $\begin{array}{l}\mathrm{F} \\
\mathrm{F} \\
\mathrm{C}\end{array}$ \\
\hline \multirow{2}{*}{$\begin{array}{c}\text { Dorcadospyris } \\
\text { ateuchus }\end{array}$} & $\begin{array}{l}7-1,51-53 \mathrm{~cm} \\
7-2,50-52 \mathrm{~cm} \\
7-3,50-52 \mathrm{~cm} \\
7-4,50-52 \mathrm{~cm} \\
7-5,51-53 \mathrm{~cm} \\
7-6,51-53 \mathrm{~cm} \\
7, \mathrm{CC}\end{array}$ & \begin{tabular}{|l|}
$C$ \\
$C$ \\
$C$ \\
$C$ \\
$C$ \\
$C$ \\
$C$
\end{tabular} & \begin{tabular}{l|}
$\mathrm{M}$ \\
$\mathrm{G}$ \\
$\mathrm{M}$ \\
$\mathrm{M}$ \\
$\mathrm{M}$ \\
$\mathrm{G}$ \\
$\mathrm{G}$
\end{tabular} & & & & + & $\begin{array}{l}+ \\
+ \\
+ \\
+ \\
+\end{array}$ & $-{ }^{\mathrm{R}}+$ & $\begin{array}{l}\mathrm{R} \\
+ \\
+\end{array}$ & $\begin{array}{l}+ \\
+ \\
+ \\
+ \\
+ \\
+ \\
+\end{array}$ & \begin{tabular}{l|l} 
& \\
+ & $\mathrm{R}$ \\
+ & \\
+ & $\mathrm{R}$ \\
\end{tabular} & \begin{tabular}{|l|}
$F$ \\
$F$ \\
$F$ \\
$F$ \\
$F$ \\
$F$ \\
$F$
\end{tabular} & - \\
\hline & $\begin{array}{l}8-2,50-52 \mathrm{~cm} \\
8-3,50-52 \mathrm{~cm} \\
8-4,50-52 \mathrm{~cm} \\
8-5,50-52 \mathrm{~cm} \\
8, \mathrm{CC}\end{array}$ & \begin{tabular}{l|l}
$C$ \\
$C$ \\
$C$ \\
$C$ \\
$C$
\end{tabular} & $\begin{array}{l}\mathrm{G} \\
\mathrm{G} \\
\mathrm{G} \\
\mathrm{G} \\
\mathrm{M}\end{array}$ & & & & + & $\begin{array}{l}- \\
- \\
+ \\
+ \\
- \\
-\end{array}$ & $\left|\begin{array}{l}\mathrm{R} \\
\mathrm{R}\end{array}\right|+$ & + & $\begin{array}{l}+ \\
+ \\
+ \\
+ \\
+\end{array}$ & \begin{tabular}{l|l}
- & $\mathrm{R}$ \\
$\mathrm{R}$ & $\mathrm{F}$ \\
+ & $\mathrm{F}$ \\
\end{tabular} & $\begin{array}{l}F \\
F \\
F \\
F \\
F\end{array}$ & \\
\hline \multirow[t]{2}{*}{$\begin{array}{l}\text { Theocyrtis } \\
\text { tuberosa }\end{array}$} & $\begin{array}{l}9-1,50-52 \mathrm{~cm} \\
9-2,50-52 \mathrm{~cm} \\
9-3,49-51 \mathrm{~cm} \\
9-4,50-52 \mathrm{~cm} \\
9, \mathrm{CC} \\
\end{array}$ & \begin{tabular}{|l|}
$C$ \\
$C$ \\
$C$ \\
$C$ \\
$F$
\end{tabular} & \begin{tabular}{l|}
$\mathrm{M}$ \\
$\mathrm{M}$ \\
$\mathrm{M}$ \\
$\mathrm{G}$ \\
$\mathrm{M}$ \\
\end{tabular} & & $\begin{array}{l}- \\
- \\
- \\
- \\
-\end{array}$ & \begin{tabular}{r|r}
- & \\
- \\
$\mathrm{R}$ \\
+ \\
$\mathrm{R}$
\end{tabular} & \begin{tabular}{l|l}
$\mathrm{F}$ & $\mathrm{R}$ \\
& + \\
$\mathrm{R}$ & $\mathrm{R}$ \\
$\mathrm{R}$ & $\mathrm{R}$ \\
$\mathrm{R}$ & \\
\end{tabular} & \begin{tabular}{l|l}
$\mathrm{R}$ & $\mathrm{R}$ \\
+ & $\mathrm{R}$ \\
$\mathrm{R}$ & + \\
$\mathrm{R}$ & $\mathrm{R}$ \\
+ \\
\end{tabular} & $\begin{array}{l}\mathrm{F} \\
\mathrm{R} \\
\mathrm{F} \\
\mathrm{R}\end{array}$ & + & & \begin{tabular}{l|l}
$\mathrm{R}$ & $\mathrm{F}$ \\
+ & \\
+ & $\mathrm{F}$ \\
$\mathrm{R}$ & \\
- &
\end{tabular} & $F+$ & \\
\hline & $\begin{array}{l}10-1,50-52 \mathrm{~cm} \\
10-2,50-52 \mathrm{~cm} \\
10, \mathrm{CC}\end{array}$ & \begin{tabular}{l|}
$C$ \\
$C$ \\
$C$
\end{tabular} & \begin{tabular}{|l|}
$\mathrm{M}$ \\
$\mathrm{M}$ \\
$\mathrm{M}$
\end{tabular} & $\begin{array}{r}+ \\
-\mathrm{R} \\
\end{array}$ & \begin{tabular}{|l|l}
$\mathrm{R}$ & - \\
$\mathrm{R}$ & $\mathrm{F}$ \\
- & $\mathrm{F}$ \\
\end{tabular} & \begin{tabular}{l|l|}
- & $F$ \\
$F$ & $F$ \\
$F$ & $F$ \\
\end{tabular} & \begin{tabular}{|l|l}
$\mathrm{R}$ & - \\
$\mathrm{F}$ & + \\
$\mathrm{F}$ & $\mathrm{R}$ \\
\end{tabular} & \begin{tabular}{l|l|}
- & $\mathrm{R}$ \\
+ & + \\
$\mathrm{R}$ & + \\
\end{tabular} & - & \begin{tabular}{|l|}
$\mathrm{R}$ \\
$\mathrm{R}$ \\
\end{tabular} & & 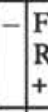 & $\begin{array}{l}\mathrm{F} \\
\mathrm{R} \\
+\end{array}$ & \\
\hline T. bromia & $\begin{array}{l}11-1,99-101 \mathrm{~cm} \\
11, \text { CC }\end{array}$ & $\begin{array}{l}C \\
C\end{array}$ & & \begin{tabular}{|l|}
$\mathrm{F}$ \\
$\mathrm{F}$
\end{tabular} & +- & - & $\mathrm{F}$ & - & & - & & & & \\
\hline \multirow{3}{*}{$\begin{array}{l}\text { Thyrsocyrtis } \\
\text { triacantha }\end{array}$} & $\begin{array}{l}12-1,130-2 \mathrm{~cm} \\
12-2,50-52 \mathrm{~cm} \\
12-3,50-52 \mathrm{~cm} \\
12-4,50-52 \mathrm{~cm} \\
12-5,50-52 \mathrm{~cm} \\
12, \mathrm{CC}\end{array}$ & $\begin{array}{l}\mathrm{C} \\
\mathrm{C} \\
\mathrm{C} \\
\mathrm{C} \\
\mathrm{C} \\
\mathrm{C}\end{array}$ & $\begin{array}{l}G \\
G \\
G \\
G \\
G \\
G\end{array}$ & C & & & & & & & & & & \\
\hline & $\begin{array}{l}13-1,50-52 \mathrm{~cm} \\
13-2,50-52 \mathrm{~cm} \\
13-3,50-52 \mathrm{~cm} \\
13-4,50-52 \mathrm{~cm} \\
13, \mathrm{CC}\end{array}$ & $\begin{array}{l}C \\
C \\
C \\
C \\
C \\
\end{array}$ & \begin{tabular}{|l|}
$G$ \\
$G$ \\
$G$ \\
$G$ \\
$G$ \\
\end{tabular} & C & & & & & & & & & & \\
\hline & $\begin{array}{l}14-1,50-52 \mathrm{~cm} \\
14-2,50-52 \mathrm{~cm} \\
14-3,50-52 \mathrm{~cm} \\
14, \mathrm{CC}\end{array}$ & \begin{tabular}{|l|}
$C$ \\
$C$ \\
$C$ \\
$C$
\end{tabular} & \begin{tabular}{|l|}
$G$ \\
$G$ \\
$G$ \\
$G$
\end{tabular} & \begin{tabular}{l|}
$\mathrm{C}$ \\
$\mathrm{C}$ \\
$\mathrm{C}$ \\
$\mathrm{C}$ \\
\end{tabular} & & & & & & & & & & \\
\hline \multirow[t]{2}{*}{$\begin{array}{l}\text { Theocampe } \\
\text { mongolfieri }\end{array}$} & $\begin{array}{l}15-2,50-52 \mathrm{~cm} \\
15-3,50-52 \mathrm{~cm} \\
15-4,50-52 \mathrm{~cm} \\
15-5,51-53 \mathrm{~cm} \\
15-6,50-52 \mathrm{~cm} \\
15, \mathrm{CC}\end{array}$ & \begin{tabular}{l|}
$C$ \\
$C$ \\
$C$ \\
$C$ \\
$C$ \\
$C$
\end{tabular} & $\begin{array}{l} \\
G \\
G \\
G \\
G \\
G\end{array}$ & $\begin{array}{l}\mathrm{C} \\
\mathrm{C} \\
\mathrm{C} \\
\mathrm{C} \\
\mathrm{C} \\
\mathrm{C}\end{array}$ & & & & & & & & & & \\
\hline & $\begin{array}{l}16-2,47-49 \mathrm{~cm} \\
16, \mathrm{CC}\end{array}$ & \begin{tabular}{l|}
$\mathrm{C}$ \\
$\mathrm{C}$
\end{tabular} & \begin{tabular}{|l|}
$\mathrm{G}$ \\
$\mathrm{M}$
\end{tabular} & $\begin{array}{l}\mathrm{F} \\
+\end{array}$ & & & & & & & & & & \\
\hline \multirow{2}{*}{$\begin{array}{l}\text { Lower } \\
\text { Eocene }\end{array}$} & $\begin{array}{l}17-1,50-52 \mathrm{~cm} \\
17, \mathrm{CC}\end{array}$ & \begin{tabular}{|l|}
$\mathrm{C}$ \\
$\mathrm{M}$ \\
\end{tabular} & & + & & & & & & & & & & \\
\hline & $\begin{array}{l}18-1,120-2 \mathrm{~cm} \\
18-2,43-45 \mathrm{~cm} \\
18-3,143-5 \mathrm{~cm}\end{array}$ & $\begin{array}{l}\mathrm{M} \\
\mathrm{C} \\
\mathrm{R}\end{array}$ & & & & & & & & & & & & \\
\hline
\end{tabular}

Note: See text for explanation of symbols. 
assemblage was recovered from the next core taken, Core 6. It belongs to the Calocycletta virginis Zone (Upper Oligocene according to nannofossil data). Abundant and well-preserved radiolarian assemblages are found in Cores 6 to 8 but the Radiolaria in Cores 9 and 10 shows signs of solution. In addition to polycystine Radiolaria, numerous Orosphaerids are present in Cores 7 to 9 . Cores 7 and 8 belong to the Dorcadospyris ateuchus Zone; Cores 9 and 10 to the Theocyrtis tuberosa Zone. Core 11 is in the Thyrsocyrtis bromia Zone (Upper Eocene according to nannofossil data) and Cores 12,13, and 14 (to 14-3) all lie within the Thyrsocyrtis triacantha Zone. The Theocampe mongolfieri Zone extends from 14, CC to Core 16, Section 2. Below this latter level, the assemblage is quite diverse, is not well preserved, and may be said only to be Lower Eocene.

\section{Site 221}

Radiolaria are either absent or so rare as to preclude age determinations. At the top of the hole, the radiolarians are probably masked by detrital material belonging to the Indus Cone. Beneath this there is a brown clay section which changes to nanno ooze in Core 16 . Within Core 18, siliceous nodules were observed; one, at level 18-6, 58-60 $\mathrm{cm}$, was sampled and contains rich and well-preserved radiolarian fauna belonging to the Podocyrtis mitra Zone. Fish debris was noted in Cores 14,15, and 17.

\section{Site 222}

The first three cores at Site 222 ( 0 to 110 meters below the sea floor) contain a few, well-preserved Radiolaria. Species such as Spongaster tetras tetras, Ommatartus tetrathalamus and Euchitonia furcata are present and are typical of a low-latitude assemblage. The cores also contain numerous diatoms, sponge spicules, and silicoflagellates. Cores 4,5 , and 7 contain rare radiolarians, including Orosphaerid fragments. The remainder of the samples from cores taken at this site are barren of Radiolaria.

\section{Site 223}

A variable radiolarian fauna was found in Core 1 through Core 20, Section 2 ( 0 to 420 meters below the sea floor; see Table 3). The fauna in Cores 1 through 7 is not diverse (making zonation difficult in this part of Hole 223), and there is considerable masking by detritus, diatoms, and Orosphaerid fragments. The fauna is richer and more diverse in Core 8 through Core 20, Section 2. Cores 1 through 3 are Pleistocene in age. Some elements of Nigrini's (1971) Pleistocene zonation are present, but, owing to drilling between cores and detrital masking, the zones are not well defined. Cores 4 and 5 , which were cored contiguously, appear to be Pliocene. However, Pterocanium prismatium is virtually absent (a single specimen was observed in the core catcher of Core 5). Stichocorys peregrina is present below level 4-3, 50-52 cm; Spongaster pentas is practically absent from both Cores 4 and 5 . Hence, on negative evidence, Cores 4 and 5 are placed in the $P$. prismatium Zone. In the lower part of Core $6, S$. pentas occurs rarely with few to common $S$. peregrina and
Ommatartus penultimus. Hence, material in Core 6 probably belongs to the $S$. pentas Zone. Between Cores 6 and 7 there is a 47-meter drilled interval. Radiolaria are rare in samples taken from Sections 7-2, 7-3 and 7-4. However, in Samples 7-5, 50-52 cm; 7-6, $48-50 \mathrm{~cm}$; and 7, CC, there is a good fauna containing well-developed $O$. penultimus and rare Solenosphaera omnitubus and Stichocorys delmontensis; S. peregrina is rare or absent. Thus, the lower part, at least, of Core 7 lies within the $S$. peregrina Zone. In the core catcher of Core 8 , there is a good fauna containing very rare specimens of $S$. peregrina. Between Cores 8 and 9 there is a 14-meter drilled interval within which the base of the $S$. peregrina Zone lies. Cores 9 and 10 lie within the Ommatartus penultimus Zone, the base of which lies between Core 11, Section 6 and Core 12, Section 2. The base of the Ommatartus antepenultimus Zone lies between Core 18, Section 4 and Core 18, Section 5. From Core 18, Section 6 to Core 20, Section 2 the radiolarian fauna belongs to the Cannartus (?) petterssoni Zone. Between Core 20, Section 2 and 36, CC, Radiolaria are either absent or so rare as to preclude a reliable age determination. The core catcher of Core 36 contains a poorly preserved but recognizable Early Eocene assemblage. Radiolaria are absent from Cores 37 through 41 .

\section{Site 224}

Radiolaria are common and well preserved in Cores 1 and 2 at Site 224 . Core 1 is Pleistocene; Core 2 is Upper Miocene (Ommatartus antepenultimus Zone); Radiolaria are absent from the remaining cored intervals.

\section{Sites 225 to 230 (Red Sea)}

At Site $225(19-4,101-103 \mathrm{~cm})$ rare, poorly preserved pyritized Radiolaria, diatoms, and silicoflagellates were observed. In the core catcher of Core 19 and in Core 20, Section 1 , there are a few radiolarians which have been recrystallized to analcite. Similarly preserved specimens are also found in the core catchers of Cores 24 and 25 at Site 227. Specific recognition and age determinations are not possible with this material. At all other drilling sites in the Red Sea, radiolarians are absent or inconsequential.

\section{RADIOLARIAN "EVENTS"}

As suggested by Riedel and Sanfilippo (Leg 7), radiolarian "events" (upper and lower taxonomic limits and evolutionary transitions) have been tabulated chronologically for Sites 219,220 , and 223 (Tables 4 and 5). In these tables, $T$ indicates the top of the range of a taxon, $B$ its bottom, and an arrow an evolutionary transition. Pairs of core sections (followed by the depth in meters below the sediment surface) between which events occurred are given in the body of the table. The letters $P, M$, and $G$ (for poor, moderate and good, respectively) are used to indicate the degree of reliability of each event at each site. A low level or reliability is usually the result of scarcity of a taxon. Often a drilled interval produces artificial bunching of events. Events which occur within the same interval are bracketed and their order may be unreliable. 
TABLE 3

Radiolarians from Site 223

\begin{tabular}{|c|c|c|c|c|c|c|c|c|c|c|c|c|c|c|c|c|}
\hline Zones & Samples & 斉. & 这 & 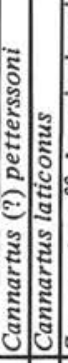 & 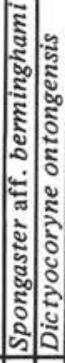 & 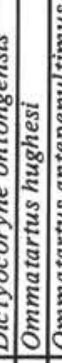 & 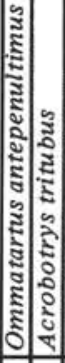 & 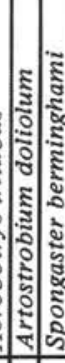 & 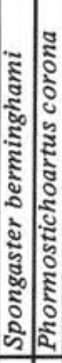 & 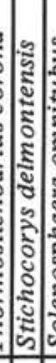 & 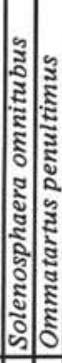 & 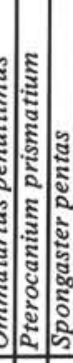 & 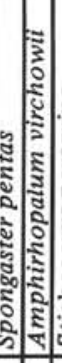 & 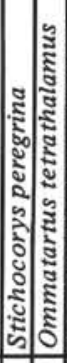 & 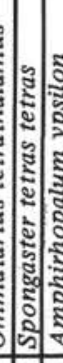 & \\
\hline \multirow{3}{*}{ Quaternary } & $\begin{array}{l}1-1,50-52 \mathrm{~cm} \\
1-2,50-52 \mathrm{~cm} \\
1-3,50-52 \mathrm{~cm} \\
\end{array}$ & \begin{tabular}{l|}
$\mathrm{C}$ \\
$\mathrm{C}$ \\
$\mathrm{F}$
\end{tabular} & \begin{tabular}{l|}
$\mathrm{G}$ \\
$\mathrm{G}$ \\
$\mathrm{G}$
\end{tabular} & & & & & & & & & & & $\begin{array}{l}\mathrm{C} \\
\mathrm{C} \\
\mathrm{F} \\
\end{array}$ & \begin{tabular}{|l|l}
$F$ & $F$ \\
$C$ & $F$ \\
$F$ & $R$ \\
\end{tabular} & $\begin{array}{l}\mathrm{F} \\
\mathrm{F} \\
\mathrm{R}\end{array}$ \\
\hline & $\begin{array}{l}2-1,120-2 \mathrm{~cm} \\
2-3,50-52 \mathrm{~cm} \\
2-4,50-52 \mathrm{~cm} \\
2-5,50-52 \mathrm{~cm} \\
2-6,50-52 \mathrm{~cm} \\
2, \mathrm{CC}\end{array}$ & \begin{tabular}{l|l}
$\mathrm{R}$ & \\
$\mathrm{R}$ & \\
$\mathrm{C}$ & \\
$\mathrm{R}$ & \\
$\mathrm{C}$ & \\
$\mathrm{C}$ & \\
\end{tabular} & $\begin{array}{l}\mathrm{G} \\
\mathrm{G} \\
\mathrm{G} \\
\mathrm{G} \\
\mathrm{G} \\
\mathrm{G}\end{array}$ & & & & & & & & & & + & $\begin{array}{l}\mathrm{C} \\
\mathrm{F} \\
\mathrm{C} \\
- \\
\mathrm{C} \\
\mathrm{C} \\
\end{array}$ & \begin{tabular}{|l|l} 
& - \\
$R$ & $F$ \\
$F$ & $F$ \\
& $F$ \\
\end{tabular} & $\begin{array}{l}- \\
\bar{F} \\
\bar{F} \\
\\
\end{array}$ \\
\hline & $\begin{array}{l}3-1,103-5 \mathrm{~cm} \\
3, \mathrm{CC}\end{array}$ & $\begin{array}{ll}\mathrm{C} \\
\mathrm{C}\end{array}$ & & & & & & & & & & & & $\begin{array}{l}\mathrm{C} \\
\mathrm{C}\end{array}$ & \begin{tabular}{|l|l}
$C$ & $R$ \\
$F$ & $R$ \\
\end{tabular} & $\begin{array}{l}\mathrm{R} \\
\mathrm{R} \\
\end{array}$ \\
\hline \multirow[t]{2}{*}{$\begin{array}{l}\text { Pterocanium } \\
\text { prismatium }\end{array}$} & $\begin{array}{l}4-2,50-52 \mathrm{~cm} \\
4-3,50-52 \mathrm{~cm} \\
4-4,50-52 \mathrm{~cm} \\
4-5,80-82 \mathrm{~cm} \\
4-6,50-52 \mathrm{~cm} \\
4, \mathrm{CC}\end{array}$ & \begin{tabular}{|l|l}
$\mathrm{F}$ & \\
$\mathrm{C}$ & \\
$\mathrm{C}$ & \\
$\mathrm{F}$ & \\
$\mathrm{F}$ & \\
$\mathrm{C}$ & \\
\end{tabular} & $\begin{array}{l}\mathrm{M} \\
\mathrm{G} \\
\mathrm{G} \\
\mathrm{G} \\
\mathrm{G} \\
\mathrm{G}\end{array}$ & & & & & & & & & & \begin{tabular}{|l|l}
$\mathrm{R}$ & \\
$\mathrm{R}$ & $\mathrm{F}$ \\
$\mathrm{R}$ & $\mathrm{F}$ \\
- & $\mathrm{F}$ \\
- & - \\
- & $\mathrm{F}$ \\
\end{tabular} & \begin{tabular}{l|l|} 
& $\mathrm{F}$ \\
$\mathrm{R}$ & $\mathrm{C}$ \\
$\mathrm{F}$ & $\mathrm{F}$ \\
$\mathrm{R}$ & $\mathrm{F}$ \\
$-\mathrm{F}$ & - \\
$\mathrm{C}$ & $\mathrm{C}$ \\
\end{tabular} & $\begin{array}{l}- \\
- \\
- \\
- \\
\end{array}$ & + \\
\hline & $\begin{array}{l}5-2,50-2 \mathrm{~cm} \\
5-3,49-51 \mathrm{~cm} \\
5-4,51-53 \mathrm{~cm} \\
5-5,50-52 \mathrm{~cm} \\
5-6,50-52 \mathrm{~cm} \\
5, \mathrm{CC}\end{array}$ & \begin{tabular}{l|l}
$C$ & \\
$C$ & \\
$C$ & \\
$C$ & \\
$C$ & \\
$C$ & \\
\end{tabular} & $\begin{array}{l}\mathrm{G} \\
\mathrm{G} \\
\mathrm{G} \\
\mathrm{G} \\
\mathrm{G} \\
\mathrm{G}\end{array}$ & & & & & & & & & \begin{tabular}{|l|l}
- & $R$ \\
- & - \\
- & - \\
- & - \\
- & - \\
+ & - \\
\end{tabular} & \begin{tabular}{l|l}
$\mathrm{R}$ & $\mathrm{R}$ \\
- & $\mathrm{F}$ \\
$-\mathrm{F}$ & $\mathrm{F}$ \\
$\mathrm{F}$ & $\mathrm{C}$ \\
$\mathrm{R}$ & $\mathrm{C}$ \\
$\mathrm{R}$ & $\mathrm{F}$ \\
$\mathrm{R}$ & $\mathrm{F}$ \\
\end{tabular} & \begin{tabular}{l|l|}
$\mathrm{F}$ & $\mathrm{C}$ \\
$\mathrm{R}$ & $\mathrm{F}$ \\
$\mathrm{C}$ & $\mathrm{C}$ \\
$\mathrm{C}$ & $\mathrm{C}$ \\
$\mathrm{F}$ & $\mathrm{C}$ \\
$\mathrm{F}$ & $\mathrm{F}$ \\
\end{tabular} & $\begin{array}{l}F \\
F \\
F \\
F \\
F \\
F\end{array} \mid+$ & \\
\hline $\begin{array}{l}\text { Spongaster } \\
\text { pentas }\end{array}$ & $\begin{array}{l}6-2,51-53 \mathrm{~cm} \\
6-3,50-52 \mathrm{~cm} \\
6-4,54-56 \mathrm{~cm} \\
6-5,50-52 \mathrm{~cm} \\
6, \text { CC }\end{array}$ & \begin{tabular}{|l|l}
$\mathrm{F}$ & \\
$\mathrm{F}$ & \\
$\mathrm{C}$ & \\
$\mathrm{R}$ & \\
$\mathrm{C}$ & \\
\end{tabular} & $\begin{array}{l}\mathrm{G} \\
\mathrm{G} \\
\mathrm{G} \\
\mathrm{M} \\
\mathrm{G}\end{array}$ & & & & & & & & \begin{tabular}{l|l}
$\mathrm{R}$ & - \\
- & $\mathrm{R}$ \\
- & $\mathrm{C}$ \\
- & $\mathrm{R}$ \\
- & $\mathrm{F}$ \\
\end{tabular} & $\frac{-}{\mathrm{R}}$ & 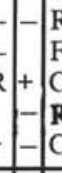 & \begin{tabular}{l|l|}
$R$ & $F$ \\
$F$ & - \\
$C$ & - \\
$R$ & - \\
$C$ & \\
\end{tabular} & - & \\
\hline \multirow[t]{2}{*}{$\begin{array}{l}\text { Stichocorys } \\
\text { peregrina }\end{array}$} & $\begin{array}{l}7-2,52-54 \mathrm{~cm} \\
7-3,52-54 \mathrm{~cm} \\
7-4,51-53 \mathrm{~cm} \\
7-5,50-52 \mathrm{~cm} \\
7-6,48-50 \mathrm{~cm} \\
7, \mathrm{CC}\end{array}$ & \begin{tabular}{l|l}
$\mathrm{R}$ & \\
$\mathrm{R}$ & \\
$\mathrm{R}$ & \\
$\mathrm{F}$ & \\
$\mathrm{C}$ & \\
$\mathrm{R}$ & \\
\end{tabular} & $\begin{array}{l}\mathrm{M} \\
\mathrm{M} \\
\mathrm{G} \\
\mathrm{G} \\
\mathrm{G} \\
\mathrm{G}\end{array}$ & & & & & & & & \begin{tabular}{l|l} 
& $\mathrm{R}$ \\
- & $\mathrm{R}$ \\
$\mathrm{R}$ & $\mathrm{R}$ \\
$\mathrm{F}$ & $\mathrm{F}$ \\
$\mathrm{R}$ & $\mathrm{R}$ \\
\end{tabular} & & & $\begin{array}{l}- \\
- \\
- \\
- \\
\mathrm{R} \\
\mathrm{R}\end{array}$ & & \\
\hline & $\begin{array}{l}8-1,120-2 \mathrm{~cm} \\
8, \mathrm{CC}\end{array}$ & $\begin{array}{ll}\mathrm{R} & \mathrm{C} \\
\mathrm{C} & \mathrm{C} \\
\end{array}$ & $\begin{array}{l}\mathrm{G} \\
\mathrm{G}\end{array}$ & & & & + & + & $\mathrm{R}$ & \begin{tabular}{l|l}
$\mathrm{R}$ & $\mathrm{C}$ \\
$\mathrm{C}$ & $\mathrm{I}$ \\
\end{tabular} & \begin{tabular}{l|l}
$\mathrm{C}$ & $\mathrm{R}$ \\
$\mathrm{F}$ & $\mathrm{F}$ \\
\end{tabular} & & & + & & \\
\hline \multirow{3}{*}{$\begin{array}{l}\text { Ommatartus } \\
\text { penultimus }\end{array}$} & $\begin{array}{l}9-1,66-68 \mathrm{~cm} \\
9-2,49-51 \mathrm{~cm} \\
9-3,88-90 \mathrm{~cm} \\
9-4,60-62 \mathrm{~cm} \\
9-5,61-63 \mathrm{~cm} \\
9-6,51-53 \mathrm{~cm} \\
9, \mathrm{CC} \\
\end{array}$ & 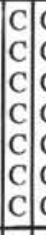 & $\begin{array}{l}\mathrm{G} \\
\mathrm{G} \\
\mathrm{G} \\
\mathrm{G} \\
\mathrm{G} \\
\mathrm{G} \\
\mathrm{G}\end{array}$ & & & & $\begin{array}{l}- \\
+ \\
- \\
- \\
+ \\
- \\
- \\
\end{array}$ & \begin{tabular}{|l|l}
$R$ & $R$ \\
$R$ \\
$R$ \\
$R$ \\
$R$ \\
$R$ \\
$R$
\end{tabular} & \begin{tabular}{l|l}
$\mathrm{R}$ & - \\
$\mathrm{R}$ & - \\
$\mathrm{R}$ & $\mathrm{R}$ \\
$\mathrm{R}$ & - \\
$\mathrm{R}$ & + \\
$\mathrm{R}$ & - \\
$\mathrm{R}$ & - \\
\end{tabular} & \begin{tabular}{l|l}
$C$ & \\
$C$ & \\
$C$ & 1 \\
$C$ & 1 \\
$C$ & 1 \\
$C$ & 1 \\
$C$ & $F$ \\
\end{tabular} & \begin{tabular}{l|l}
$A$ & $C$ \\
$C$ & $C$ \\
$F$ & $C$ \\
$C$ & $C$ \\
$F$ & $C$ \\
$F$ & $C$ \\
$R$ & $C$ \\
\end{tabular} & & & & & \\
\hline & $\begin{array}{l}10-1,51-53 \mathrm{~cm} \\
10-2,70-72 \mathrm{~cm} \\
10, \mathrm{CC}\end{array}$ & \begin{tabular}{|l|l|}
$\mathrm{F}$ & \\
$\mathrm{C}$ & \\
$\mathrm{C}$ & $\mathrm{C}$ \\
\end{tabular} & $\begin{array}{l}\mathrm{G} \\
\mathrm{G} \\
\mathrm{G}\end{array}$ & & & + & \begin{tabular}{|l|} 
\\
- \\
$\mathrm{R}$ \\
\end{tabular} & $\begin{array}{l}-1 \\
-F \\
-F\end{array}$ & \begin{tabular}{l|l|}
- & - \\
$\mathrm{R}$ & - \\
$\mathrm{F}$ & $\mathrm{R}$ \\
\end{tabular} & \begin{tabular}{|l|l}
$\mathrm{F}$ & 1 \\
$\mathrm{C}$ & $\mathrm{I}$ \\
$\mathrm{C}$ & $\mathrm{I}$ \\
\end{tabular} & \begin{tabular}{l|l|}
$\mathrm{F}$ & $\mathrm{C}$ \\
$\mathrm{F}$ & $\mathrm{C}$ \\
$\mathrm{F}$ & $\mathrm{C}$ \\
\end{tabular} & & & & & \\
\hline & $\begin{array}{l}11-1,110-2 \mathrm{~cm} \\
11-2,118-20 \mathrm{~cm} \\
11-3,50-52 \mathrm{~cm} \\
11-4,50-52 \mathrm{~cm} \\
11-5,50-52 \mathrm{~cm} \\
11-6,50-52 \mathrm{~cm} \\
11, \mathrm{CC}\end{array}$ & \begin{tabular}{l|l}
$\mathrm{C}$ & \\
$\mathrm{C}$ & \\
$\mathrm{F}$ & \\
$\mathrm{C}$ & \\
$\mathrm{F}$ & \\
$\mathrm{C}$ & \\
$\mathrm{C}$ & \\
\end{tabular} & & & $\begin{array}{l}- \\
- \\
- \\
F \\
F \\
\end{array}$ & \begin{tabular}{|l|l}
- & \\
- & \\
+ & \\
- & \\
& \\
$F$ & $R$ \\
$C$ & $F$ \\
\end{tabular} & \begin{tabular}{l|l}
$\mathrm{R}$ \\
$\mathrm{R}$ \\
+ \\
$\mathrm{R}$ \\
$\mathrm{R}$ \\
$\mathrm{F}$ & - \\
\end{tabular} & \begin{tabular}{l|l}
$\mathrm{R}$ & $\mathrm{F}$ \\
$\mathrm{F}$ & $\mathrm{R}$ \\
$\mathrm{R}$ & $\mathrm{F}$ \\
- & $\mathrm{F}$ \\
- & \\
+ & $\mathrm{F}$ \\
$\mathrm{R}$ & $\mathrm{F}$ \\
\end{tabular} & \begin{tabular}{l|l}
$\mathrm{F}$ & $\mathrm{F}$ \\
$\mathrm{R}$ & $\mathrm{F}$ \\
$\mathrm{R}$ & - \\
$\mathrm{R}$ & - \\
$\mathrm{F}$ & $\mathbf{R}$ \\
$\mathrm{F}$ & $\mathrm{F}$ \\
\end{tabular} & \begin{tabular}{l|l}
$C$ & 1 \\
$C$ & 1 \\
$C$ & 1 \\
$C$ & - \\
$C$ & - \\
$C$ & - \\
$C$ & \\
\end{tabular} & \begin{tabular}{l|l}
$\mathrm{F}$ & $\mathrm{C}$ \\
$\mathrm{R}$ & $\mathrm{C}$ \\
$\mathrm{R}$ & $\mathrm{C}$ \\
+ & $\mathrm{C}$ \\
- & $\mathrm{C}$ \\
- & $\mathrm{C}$ \\
- & $\mathrm{F}$ \\
\end{tabular} & & & & & \\
\hline
\end{tabular}


TABLE 3 - Continued

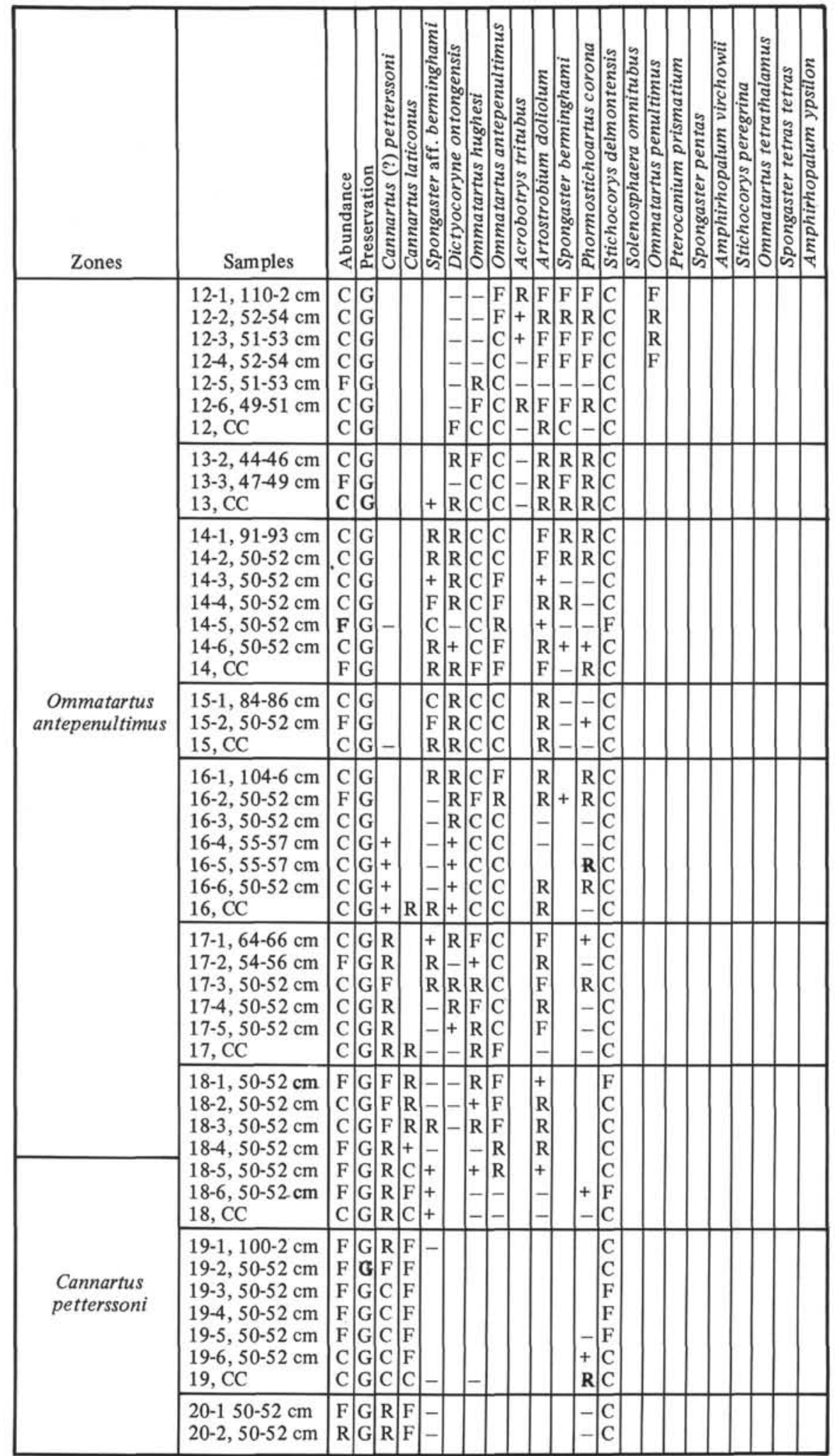

Note: See text for an explanation of symbols. 
TABLE 4

Radiolarian "Events," Site 223

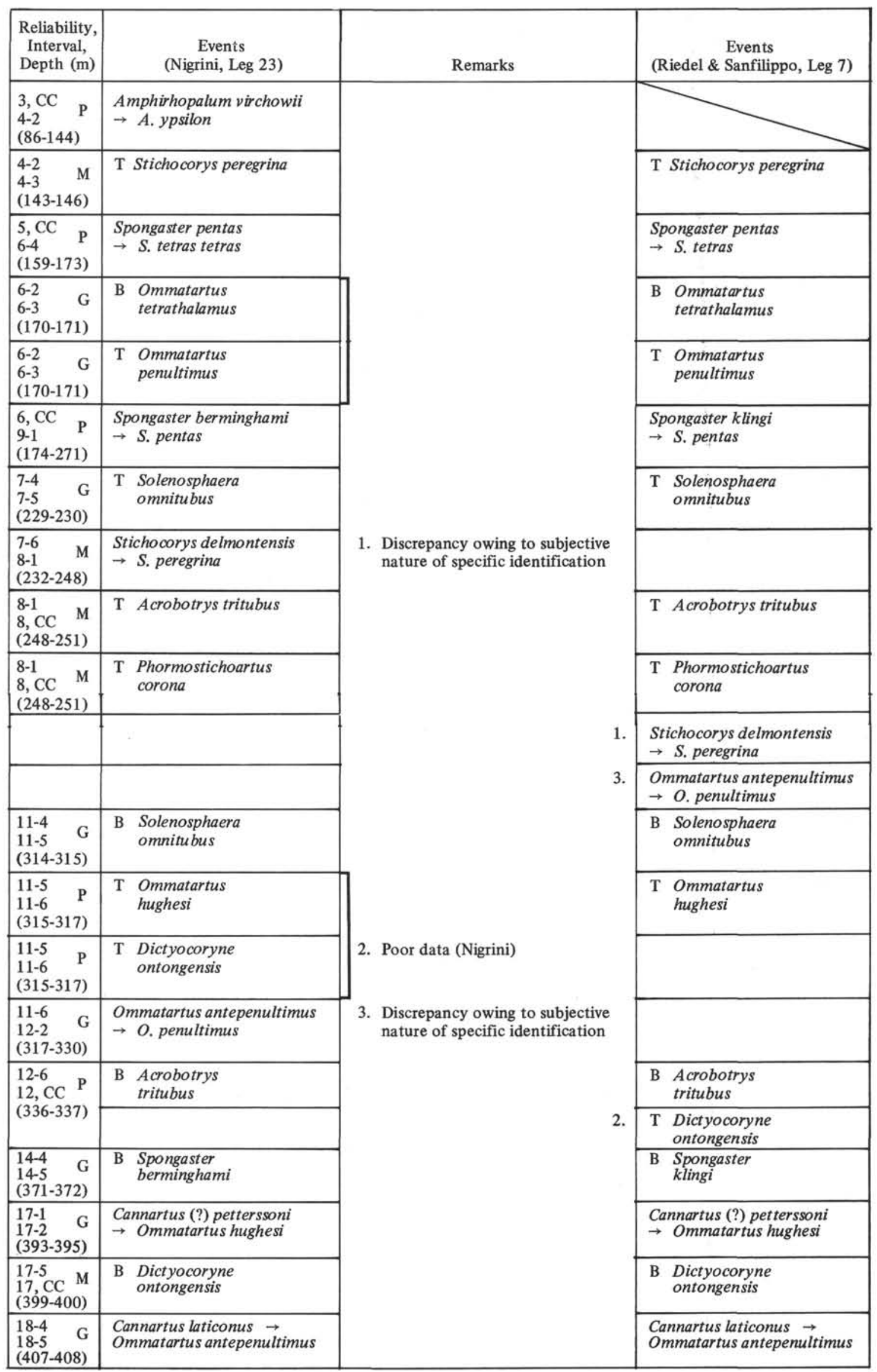

Note: See text for an explanation of symbols. 
TABLE 5

Radiolarian "Events," Sites 219 and 220

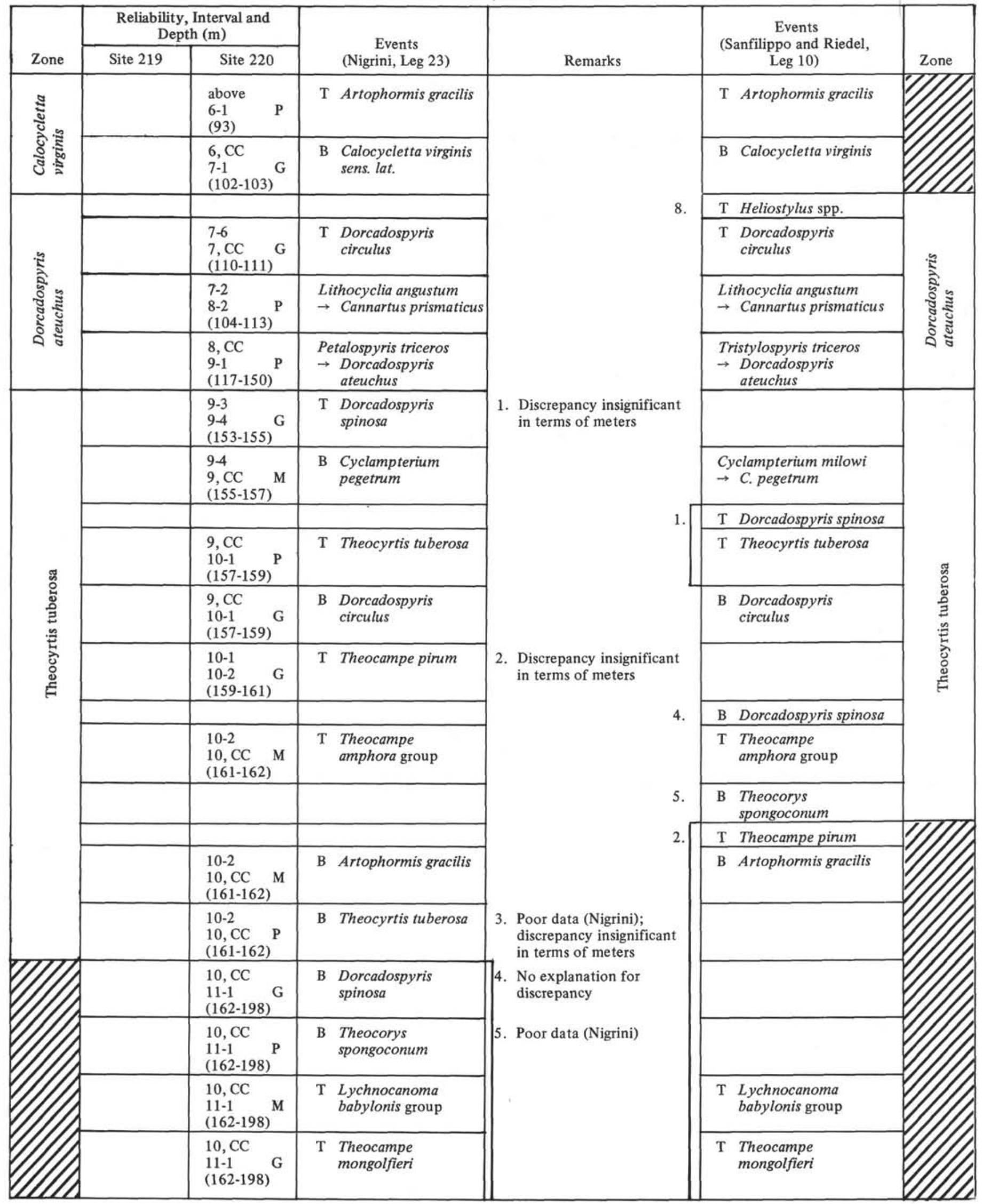


TABLE S - Continued

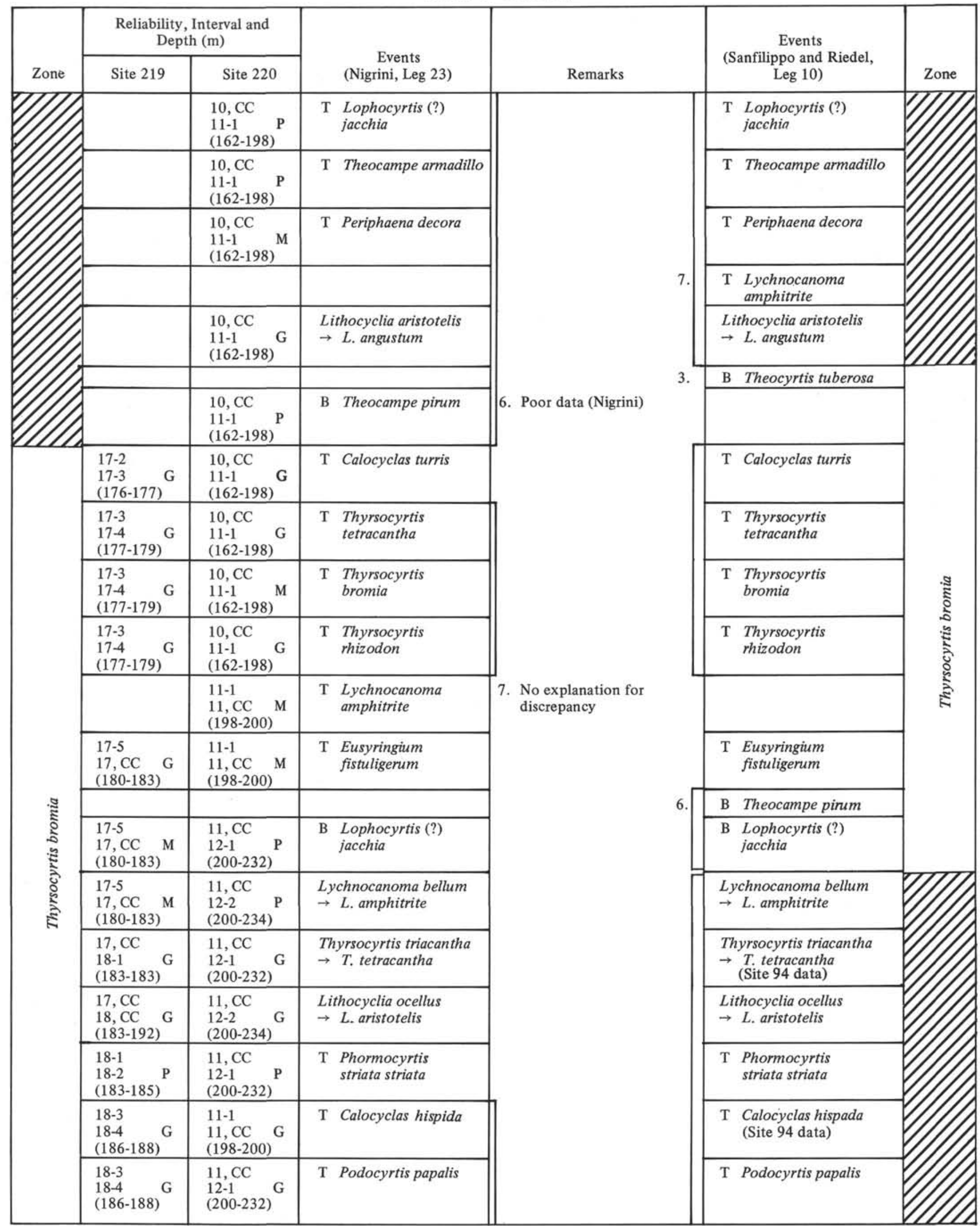


TABLE 5 - Continued

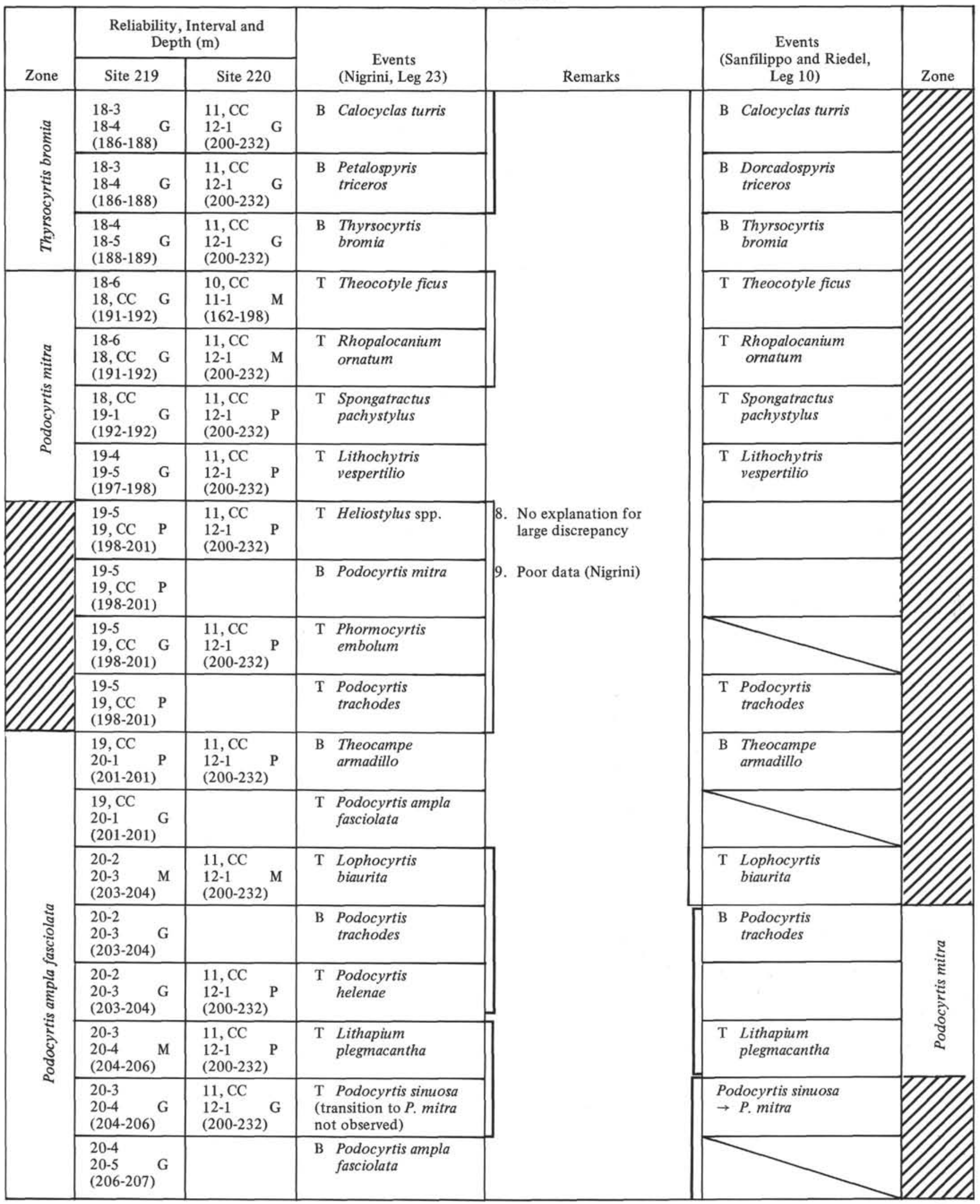


TABLE 5 - Continued

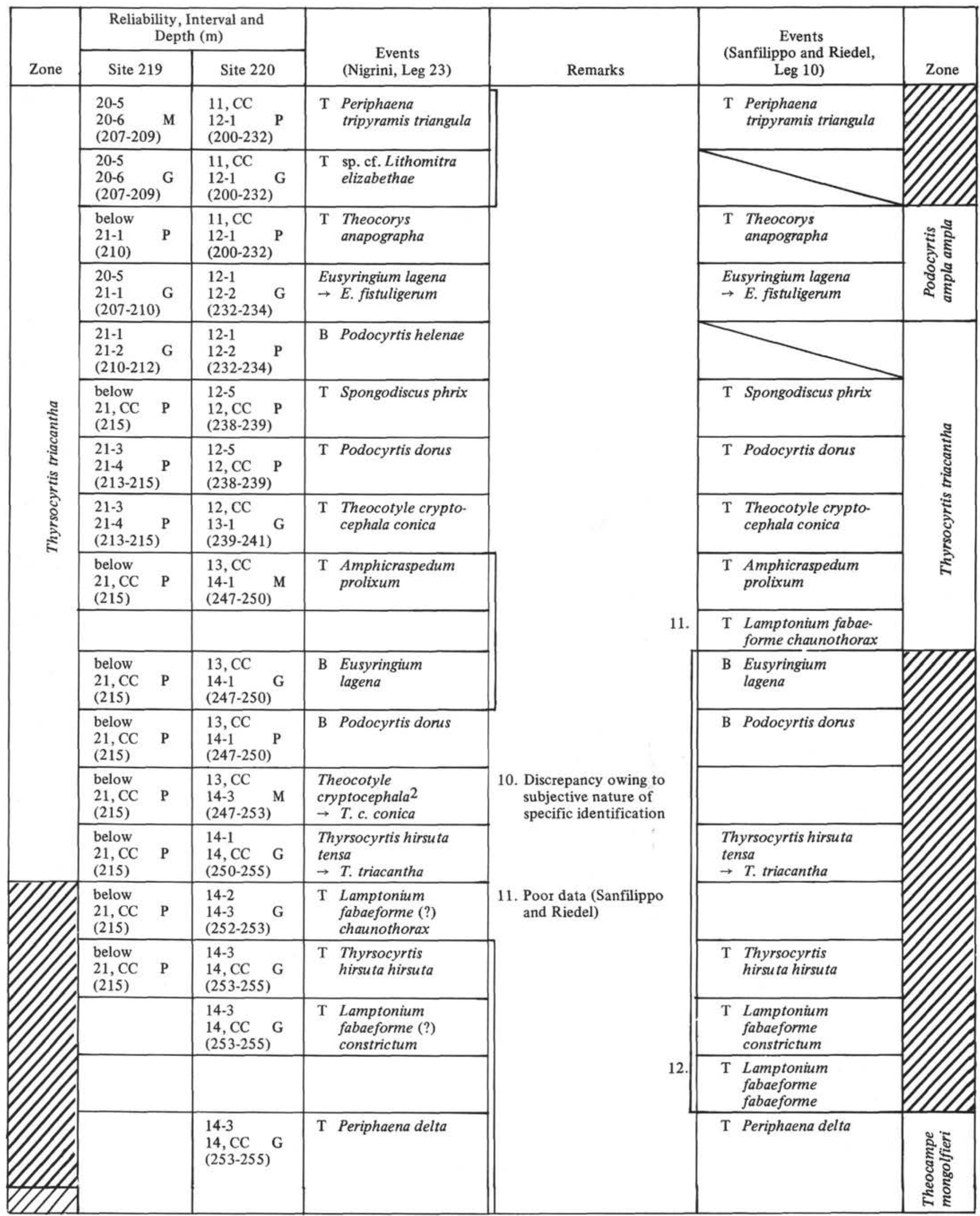


TABLE 5 - Continued

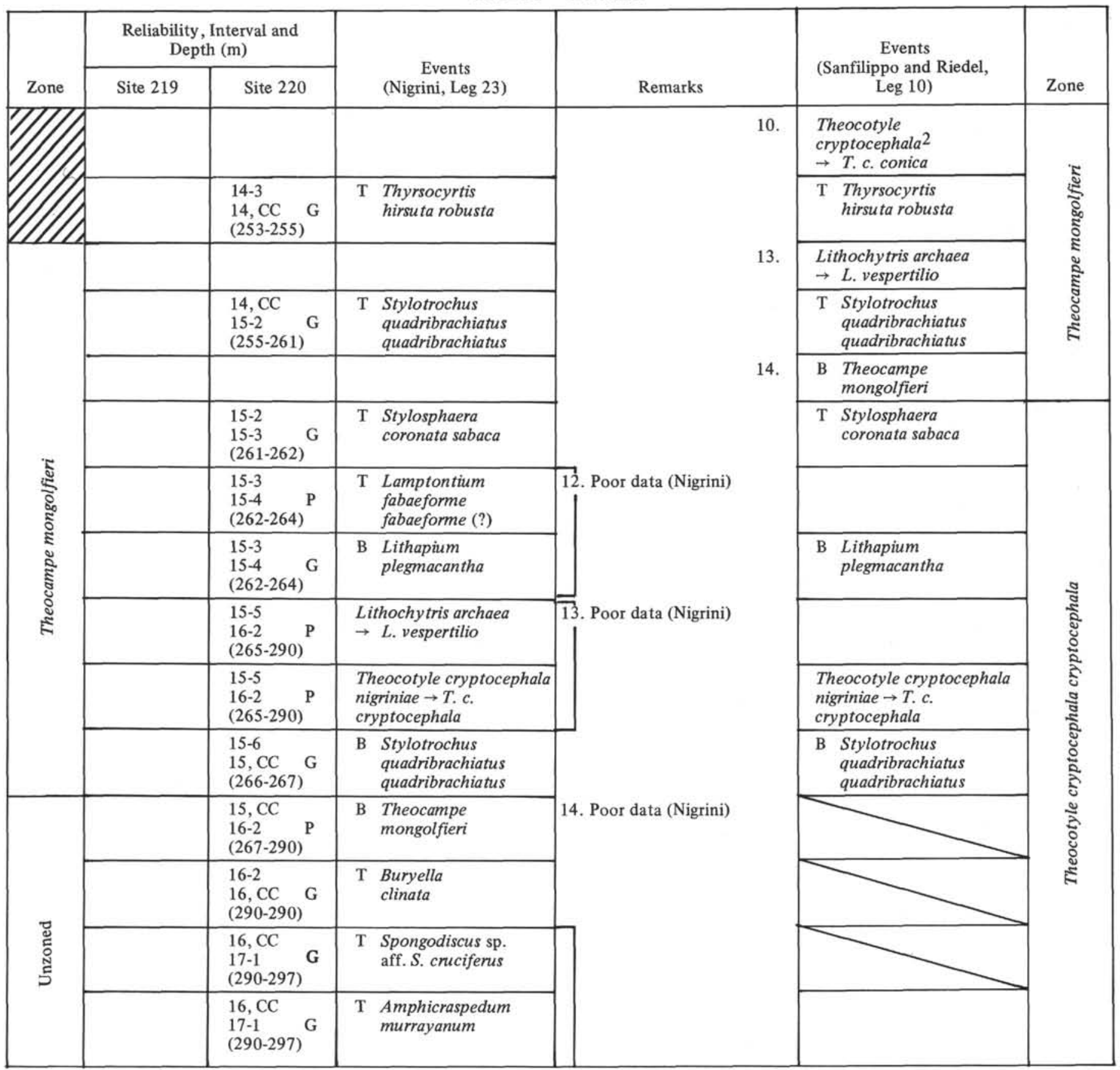

Note: See text for explanation of symbols.

The order of radiolarian events determined by the present author (Tables 4 and 5) is compared with that determined by Riedel and Sanfilippo in the Leg 7 (1971) and Leg 10 (1973) reports. For the most part, the sequence of events from the two sources is the same. Discrepancies are indicated by notes, numbered sequentially, beside the Leg 23 column. Corresponding numbers are placed next to the Riedel and Sanfilippo column. Some events noted by this author, but not by Riedel and Sanfilippo, are included, and there is a diagonal line across the box in the opposite column. Events recorded by Riedel and Sanfilippo, but not herein, are omitted entirely. Some discrepancies (i.e., top of D. spinosa, top of $T$. pirum, bottom of $T$. tuberosa) are insignificant when considered in terms of meters of sediment between events. Others (i.e., bottom of $T$. spongoconum, bottom of $T$. pirum, bottom of $P$. mitra, top of $L$. fabaeforme (?) chaunothorax, top of $L$. fabaeforme fabaeforme, bottom of $T$. mongolfieri, transition from $L$. archaea to $L$. vespertilio, and top of $D$. ontongensis) are the result of poor data, meaning rare occurrence in most cases. Picking the level at which an evoluntionary transition occurs involves subjective decisions, and this seems to be the reason for discrepancies in picking the levels at which $T$. cryptocephala cryptocophala becomes $T$. cryptocephala conica, $S$. delmontensis becomes $S$. peregrina, and $O$. antepenultimus becomes $O$. penultimus. There is no 
obvious explanation for discrepancies in picking the top of $L$. amphitrite, the bottom of $D$. spinosa, or for the very large discrepancy in picking the top of Heliostylus spp.

\section{SYSTEMATIC PALEONTOLOGY}

At the family level, the systematics suggested by Riedel (1967b) are followed herein. Within the families, genera are arranged alphabetically and species alphabetically within genera.

In the synonomies of species, the only references included are the original description and illustration, a modern description of the species, and in some cases, a recent paper giving additional morphological and distributional information about the species.

Type specimens will be deposited in the U.S. National Museum, Washington, D.C.

\section{Order POLYCYSTINA Ehrenberg}

Polycystina Ehrenberg, 1838, emend. Riedel, 1967b

Suborder SPUMELLARIA Ehrenberg, 1875 5(1). Family COLLOSPHAERIDAE Müller, 1858

5(1)A. Genus SOLENOSPHAERA Haeckel, 1887

5(1)Aa. Solenosphaera omnitubus Riedel and Sanfilippo (Plate 5, Figure 1)

Solenosphaera omnitubus Riedel and Sanfilippo, 1971, p. 1586, pl. $1 \mathrm{~A}$, figs. 23,24 ; pl. 4 , figs. $1,2$.

\section{5(2). Family ACTINOMMIDAE Haeckel, 1862, emend.} Riedel, 1967b

5(2)A. Genus CANNARTUS Haeckel, 1881, emend. Riedel, 1971.

5(2)Aa. Cannartus laticonus Riedel

(Plate 5, Figure 2)

Cannartus laticonus Riedel, 1959, p. 291, pl. 1, fig. 5.

5(2)Ab. Cannartus (?) petterssoni Riedel and Sanfilippo (Plate 5, Figure 3)

Cannartus (?) petterssoni conditional manuscript name proposed in Riedel and Funnel, 1964, p. 310; Riedel and Sanfilippo, 1970 , pl. 14 , fig. 3 .

Astromma petterssoni (Riedel), Petrushevskaya and Kozlova, 1972, p. 522 , pl. 12 , fig. 5 .

Remarks: Although this species resembles the type species of Astromma, A. enthomocora Ehrenberg, 1847b (Ehrenberg, 1854b, pl. 22, fig. 32), retention of it in the genus Cannartus reflects its close natural relationship to the Cannartus - Ommatartus lineage (see, Riedel and Sanfilippo, 1971, p. 1587 and Riedel, 1971, p. $652)$.

\section{5(2)Ac. Cannartus prismaticus (Haeckel)}

(Plate 2A, Figures 1, 2)

Pipetella prismatica Haeckel, 1887, p. 305.

Cannartus prismaticus (Haeckel), Riedel and Sanfilippo, 1970, pl. 15 , fig. 1.

\section{5(2)B. Genus LITHAPIUM Haeckel, 1887}

The following species are tentatively assigned to this genus by Riedel and Sanfilippo (1970).

\section{5(2)Ba. Lithapium anoectum Riedel and Sanfilippo} (Plate 1A, Figures 1,2)

Lithapium (?) anoectum Riedel and Sanfilippo, 1970, p. 520, pl. 4, figs. 4, 5; Sanfilippo and Riedel, 1973, p. 516, pl. 24, figs. 6, 7.

5(2)Bb. Lithapium plegmacantha Riedel and Sanfilippo (Plate 1A, Figures 3-5)

Lithapium (?) plegmacantha Riedel and Sanfilippo, 1970, p. 520, pl. figs. 2, 3; Sanfilippo and Riedel, 1973, p. 516, pl. 3, figs. 1, 2; pl. 24 , figs. 8,9 .
5(2)C. Genus OMMATARTUS Haeckel, 1881, emend. Riedel, 1971 5(2)Ca. Ommatartus antepenultimus Riedel and Sanfilippo (Plate 5, Figures 5, 6)

Panarium antepenultimum, conditional manuscript name proposed by Riedel and Funnell, 1964, p. 311.

Ommatartus antepenultimus, Riedel and Sanfilippo, 1970, pl. 14, fig. 4 .

\section{5(2)Cb. Ommatartus hughesi (Campbell and Clark) (Plate 5, Figure 4)}

Ommatocampe hughesi Campbell and Clark, 1944, p. 23, pl. 3, fig. 12.

Ommatartus hughesi Campbell and Clark, Riedel and Sanfilippo, 1970 , p. 521.

Astromma hughesi (Campbell and Clark), Petrushevskaya and Kozlova, 1972, p. 522, pl. 12, fig. 4.

Remarks: See remarks for Cannartus (?) petterssoni.

\section{5(2)Cc. Ommatartus penultimus (Riedel)} (Plate 5, Figures 7, 8)

Panarium penultium Riedel, 1957a, p. 76, pl. 1, fig. 1.

Ommatartus penultimus (Riedel), Riedel and Sanfilippo (sensu. stricto), 1970 , p. 521.

\section{5(2)Cd. Ommatartus tetrathalamus (Haeckel) (Plate 6, Figure 1)}

Panartus tetrathalamus Haeckel, 1887, p. 378, pl. 40, fig. 3; Nigrini, 1967 , p. 30 , pl. 1 , figs. $4 a-4 d$.

\section{5(2)D. Genus SPONGATRACTUS Haeckel, 1887, emend.} Sanfilippo and Riedel, 1973.

Petrushevskaya and Kozlova (1972) synonymize the genera Spongosphaera Ehrenberg, 1847b, and Spongatractus Haeckel, 1887. However, the type species of Spongosphaera, Spongosphaera polycantha Müller, 1857 (illustrated in 1858), is not closely related to the type species of Spongatractus, Spongosphaera pachystylus Ehrenberg, and so the synonomy seems to be erroneous.

\section{5(2)Da. Spongatractus balbis Sanfilippo and Riedel} (Plate 1A, Figures 6,7)

Spongatractus balbis Sanfilippo and Riedel, 1973, p. 518, pl. 2, figs. 25 , figs. 1,2 .

\section{$5(2) \mathrm{Db}$. Spongatractus pachystylus (Ehrenberg)} (Plate 1A, Figures 8-11)

Spongosphaera pachystyla Ehrenberg, 1873, p. 256; 1875, pl. 26, fig. 3.

Spongatractus pachystylus (Ehrenberg), Sanfilippo and Riedel, 1973 , p. 5 , 9 , pl. 2, figs. $4-6$; pl. 25 , fig. 3.

\section{5(2)E. Genus STYLOSPHAERA Ehrenberg, 1847}

See Sanfilippo and Riedel, 1973.

\section{5(2)Ea. Stylosphaera coronata coronata Ehrenberg} (Plate 1B, Figures 1-3)

Stylosphaera coronata Ehrenberg, 1873 , p. $258 ; 1875$, pl. 25 , fig. 4 . Stylosphaera coronata coronata Ehrenberg, Sanfilippo and Riedel, 1973 , pl. 1, figs. $13-17$; pl. 25, fig. 4 .

Remarks: Petrushevskaya and Kozlova (1972) place this species in the genus Stylatractus (type species: Stylatractus neptunus Haeckel, 1887). However, it appears to be more closely related to the type species of Stylosphaera (Stylosphaera hispida Ehrenberg, 1854 a), p. $246 ; 1854$, pl. 36 , fig. 26 , and that generic name is retained herein.

5(2)Eb. Stylosphaera coronata sabaca Sanfilippo and Riedel (Plate 1B, Figure 4)

Stylosphaera coronata sabaca Sanfilippo and Riedel, 1973, pl. 1, fig. 18 ; pl. 25, figs. $7,8$. 


\section{5(3). Family PHACODISCIDAE Haeckel, 1881}

Petrushevskaya and Kozlova (1972) consider this group to be a subfamily of the family Coccodiscidae Haeckel, 1862.

\section{5(3)A. Genus HELIOSTYLUS Haeckel, 1881, emend. Sanfilippo and Riedel, 1973}

It is not yet possible to satisfactorily define species within this genus; therefore, all representatives are recorded as Heliostylus $\mathrm{sp}(\mathrm{p})$. (Plate 1B, Figures 5-7.)

5(3)B. Genus PERIPHAENA Ehrenberg, 1873, emend. Sanfilippo and Riedel, 1973

5(3)Ba, Periphaena decora Ehrenberg

(Plate 1C, Figures 1-6, Plate 2A, Figure 3)

Periphaena decora Ehrenberg, 1873, p. $246 ; 1875$, pl. 28, fig. 6; Riedel 1957 b, p. 258 , pl. 62, fig. 1; Sanfilippo and Riedel, p. 523,1973 , pl. 8 , figs. $8-10$; pl. 27 , figs. $2-5$.

Remarks: Included under this name are forms with and without projecting spines. A heavier shelled form, referred to as $P$. (?) dupla by Petrushevskaya and Kozlova (1972), is not included.

5(3)Bb. Periphaena delta Sanfilippo and Riedel (Plate 1C, Figure 7)

Periphaena delta Sanfilippo and Riedel, 1973, p. 523, pl. 8, figs. 11, $12 ;$ pl. 27 , figs. 6,7 .

5(3)Bc. Periphaena tripyramis tripyramis (Haeckel) (Plate 1C, Figure 8)

Triactis tripyramis Haeckel, 1887, p. 432, pl. 33, fig. 6 .

Triactis tripyramis tripyramis Haeckel, Riedel and Sanfilippo, 1970, p. 521 , pl. 4 , fig. 8 .

Periphaena tripyramis tripyramis (Haeckel), Sanfilippo and Riedel, 1973 , p. 523, pl. 9, figs. 7-9.

\section{5(3)Bd. Periphaena tripyramis triangula (Sutton)}

(Plate 1D, Figures 1, 2)

Phacotriactis triangula Sutton, 1896, p. 61.

Triactis tripyramis triangula (Sutton), Riedel and Sanfilippo, 1970, p. 521 , pl. 4 , figs. 9,10 .

Periphaena tripyramis triangula (Sutton), Sanfilippo and Riedel, 1973, p. 523, pl. 9, figs. 10, 11.

\section{5 (4). Family COCCODISCIDAE Haeckel, 1862}

5(4)A. Genus LITHOCYCLIA Ehrenberg, 1847, emend. Riedel and Sanfilippo, 1970

5(4)Aa. Lithocyclia angustum (Riedel)

(Plate 2A, Figures 4-6)

Trigonactura angusta Riedel, 1959, p. 292, pl. 1, fig. 6 .

Lithocyclia angustum (Riedel), Riedel and Sanfilippo, 1970, p. 522, pl. 13, figs. 1, 2.

Remarks: Petrushevskaya and Kozlova (1972) place this species in the genus Trigonactinium Haeckel. However, because of its relationship to the $L$. ocellus group it seems advisable to retain it within Lithocyclia and modify the generic description as suggested by Riedel and Sanfilippo (1970, p. 522).

\section{5(4)Ab. Lithocyclia aristotelis (Ehrenberg) group (Plate 2A, Figure 7)}

Astromma aristotelis Ehrenberg, 1847b, p. 55, fig. 10.

Lithocyclia aristotelis (Ehrenberg) group, Riedel and Sanfilippo, 1970 , p. 522.

Remarks: Petrushevskaya and Kozlova (1972) place this group in the genus Astractinium Haeckel. However, for the same reasoning applied to $L$. angustum this group is retained herein in the genus Lithocyclia.
5(4)Ac. Lithocyclia aff. crux Moore

(Plate 2A, Figure 8)

Lithocyclia crux Moore, 1971, p. 737, pl. 6, fig. 4.

Remarks: This species is called Astractinium spp. in Petrushevskaya and Kozlova (1972). See remarks for $L$. angustum and $L$. aristotelis group.

\section{5(4)Ad. Lithocyclia ocellus Ehrenberg group (Plate 1D, Figures 3-6)}

Lithocyclia ocellus Ehrenberg, 1854b, pl. 36, fig. 30;1873, p. 240. Lithocyclia ocellus Ehrenberg group, Riedel and Sanfilippo, 1970, p. 522, pl. 5, figs. 1, 2; Sanfilippo and Riedel, 1973, p. 523, pl. 10 , figs. 1,2 .

Remarks: Specimens observed in Sample 220-17-1 do not possess a medullary shell.

Petrushevskaya and Kozlova (1972) separate forms with two spines (Stylocyclia dimidiata Ehrenberg) and numerous spines (Astrocyclia sp.). The se variants were considered herein to belong to the $L$. ocellus group.

\section{5(5). Family SPONGODISCIDAE Haeckel, 1862, emend. Riedel, 1967b}

5(5)A. Genus AMPHICRASPEDUM Haeckel, 1881

See Sanfilippo and Riedel, 1973, p. 524.

5(5)Aa. Amphicraspedum murrayanum Haeckel (Plate 3, Figure 2)

Amphicraspedum murrayanum Haeckel, 1887, p. 523, pl. 44, fig. 10; Sanfilippo and Riedel, 1973, p. 524, pl. 10, figs. 3-6; pl. 28, fig. 1.

\section{5(5)Ab. Amphicraspedum prolixum Sanfilippo and Riedel} (Plate 1D, Figure 7)

Amphicraspedum prolixum Sanfilippo and Riedel, 1973, p. 524, pl. 10, figs. $7-11$; pl. 28 , figs. 3,4 .

\section{5(5)B. Genus AMPHIRHOPALUM Haeckel, 1887, emend. Nigrini, 1967}

5(5)Ba. Amphirhopalum virchowii (Haeckel) (Plate 6, Figure 2)

Euchitonia virchowï Haeckel, 1862, p. 503, pl. 30, figs. 1-4.

? Trigonastrum sp. aff Chitonastrum lyra Haeckel, Petrushevskaya and Kozlova, 1972, p. 527, pl. 20, fig. 3.

A mphirhopalum wirchowï (Haeckel), Dumitrica, 1973, p. 835, pl. 9, figs. 2, 4; pl. 11, fig. 6 ; pl. 21, figs. 2-13.

Remarks: see remarks for $A$. ypsilon

\section{5(5)Bb. Amphirhopalum ypsilon Haeckel (Plate 6, Figure 3)}

Amphirhopalum ypsilon Haeckel, 1887, p. 522; Nigrini, 1967, p. 35 , pl. 3, figs. 3a-d; Nigrini, 1971, p. 447 , pl. 1, figs. 7 a-c.

Remarks: Dumitrica (1973, p. 835) described a species called Amphirhopalum wirchowii (Haeckel). There is a minor spelling error and the name should be $A$. virchowii. This species is very likely the ancestor of A. ypsilon, and differs from it in having smoother, more distinct and more rounded chambers. It has previously been observed by the present author in Upper Pliocene sediments and there is a transition from $A$. virchowii to $A$. ypsilon near the Plio-Pleistocene boundary. A. ypsilon then evolves in the manner described by Nigrini (1971, p. 447). The specimens figured by Dumitrica (1973, pl. Il, fig. 6) and by Haeckel (1862, pl. 30, fig. 4) are good examples of $A$. virchowii. The arms are somewhat narrower than those illustrated by Haeckel $(1862, \mathrm{pl} .30$, figs. 1, 2). Specimens figured by Nigrini (1971, pl. 1, figs. 7b, 7c), and referred to by Dumitrica (1973) are good examples of early A. ypsilon. A. virchowii is a convenient name for the species in question, but without examining type material, it is difficult to say whether Haeckel was looking at the Pliocene form or early A. ypsilon. 
5(5)C. Genus DICTYOCORYNE Ehrenberg, 1860

5(5)Ca. Dictyocoryne ontongensis Riedel and Sanfilippo (Plate 7, Figure 3)

Dictyocoryne ontongensis Riedel and Sanfilippo, 1971, p. 1588, pl. 1E, figs. 1, 2; pl. 4, figs. 9-11.

5(5)D. Genus SPONGASTER Ehrenberg, 1860

5(5)Da. Spongaster berminghami Campbell and Clark (Plate 6, Figure 4)

Spongaster berminghami Campbell and Clark, 1944, p. 30, pl. 5, figs. $1,2$.

Spongaster klingi Riedel and Sanfilippo, 1971, p. 1589, pl. 1D, figs. $8,9,10 ;$ pl. 4 , figs. 7,8 .

\section{5(5)Db. Spongaster aff. berminghami Riedel and Sanfilippo (Plate 6, Figure 5)}

Remarks: This species is more circular than typical $S$, berminghami. Its range is below that of $S$. berminghami, and it may be the ancestral form.

\section{5(5)Dc. Spongaster pentas, Riedel and Sanfilippo} (Plate 7, Figure 1)

Spongaster pentas Riedel and Sanfilippo, 1970, p. 523, pl. 15, fig. 3.

\section{5(5)Dd. Spongaster tetras tetras Ehrenberg}

(Plate 7, Figure 2)

Spongaster tetras Ehrenberg, 1860, p. 833.

Spongaster tetras tetras Ehrenberg, Nigrini, 1967, p. 41, pl. 5, figs. 1a, $1 \mathrm{~b}$.

Remarks: Dumitrica (1973) synonymized this subspecies with $S$. tetras irregularis Nigrini because he found both forms in his Mediterranean samples. The subspecific distinction is retained herein, however: (1) because it proved to be a useful one in distinguishing low- and middle-latitude faunas in the Indian Ocean (Nigrini, 1967); and (2) only the square form is present in Site 223 material.

\section{5(5)E. Genus SPONGODISCUS Ehrenberg, 1854a}

See Sanfilippo and Riedel, 1973.

\section{5(5)Ea. Spongodiscus aff. cruciferus (Clark and Campbell)} (Plate 3, Figure 3)

Spongasteriscus cruciferus Clark and Campbell, 1942, p. 50, pl. 1, figs. 1-6, 8, 10, 11, 16-18.

Spongodiscus cruciferus (Clark and Campbell), Sanfilippo and Riedel, 1973, p. 524, pl. 11, figs. 14-17, pl. 28, figs. 10,11.

Remarks:Spongodiscus cruciferus as described by Sanfilippo and Riedel (1973) ranges much higher, into the $T$. triacantha Zone, than the form observed herein. The relationship between the two forms is unknown.

\section{5(5)Eb. Spongodiscus phrix Sanfilippo and Riedel}

$$
\text { (Plate 1D, Figures 8, 9) }
$$

Spongodiscus phrix Sanfilippo and Riedel, 1973, p. 525, pl. 12, figs.

$$
1,2 \text {; pl. } 29 \text {, fig. } 2 .
$$

Remarks: A similar form, $S$. pulcher Clark and Campbell (Plate 3 , Figure 4 herein) is common in Lower Eocene material (220-16, $C C$ to 220-18-3) but lacks the alternating thin and thick areas characteristic of $S$. phrix (cf. Sanfilippo and Riedel, 1973).

\section{5(5)Ec. Spongodiscus rhabdostylus (Ehrenberg)}

(Plate 1E, Figures 1-3)

Spongosphaera rhabdostyla Ehrenberg, 1873, p. 256; 1875, pl. 26, figs. $1,2$.

Spongodiscus rhabdostylus (Ehrenberg), Sanfilippo and Riedel, 1973 , p. 525 , pl. 13 , figs. $1-3$; pl. 30 , figs. $1,2$.
5(5)F. Genus STYLOTROCHUS Haeckel, 1862

5(5)Fa. Stylotrochus quadribrachiatus quadribrachiatus, Sanfilippo and Riedel

(Plate 1E, Figure 4)

Stylotrochus quadribrachiatus quadribrachiatus Sanfilippo and Riedel, 1973, p. 526, pl. 14, figs. 1, 2; pl. 31, figs. 1.

5(5)Fb, Stylotrochus quadribrachiatus multibrachiatus, Sanfilippo and Riedel (Plate 3, Figure 5)

Stylotrochus quadribrachiatus multibrachiatus Sanfilippo and Riedel, 1973, p. 526, pl. 14, figs. 3, 4; pl. 31, figs. 2, 3.

\section{Suborder NASSELLARIA Ehrenberg, 1875}

5(6). Family ACANTHODESMIIDAE, Haeckel, 1862, emend. Riedel, $1967 b$.

5(6)A. Genus DORCADOSPYRIS, Haeckel, 1881; emend. Goll, 1969

5(6)Aa. Dorcadospyris ateuchus (Ehrenberg) (Plate 2B, Figures 1, 2)

Ceratospyris ateuchus Ehrenberg, 1873, p. 218.

Cantharospyris ateuchus (Ehrenberg), Riedel, 1959, p. 294, pl. 22, figs. 3,4 .

Dorcadospyris ateuchus (Ehrenberg), Riedel and Sanfilippo, 1970, pl. 15 , fig. 4 .

Dorcadospyris (?) or Petalospyris (?) ateuchus (Ehrenberg), Petrushevskaya and Kozlova, 1972, p. 532.

\section{5(6)Ab. Dorcadospyris circulus (Haeckel) (Plate 2B, Figure 3)}

Gamospyris circulus Haeckel, 1887, p. 1042, pl. 83, fig. 19.

Dorcadospyris circulus (Haeckel), Moore, 1971, p. 739, pl. 8, figs. 3, 4.

5(6)Ac. Dorcadospyris spinosa Moore (Plate 2B, Figure 4)

Dorcadospyris spinosa Moore, 1971, p. 739, pl. 7, figs. 1, 2.

5(6)B. Genus PETALOSPYRIS Ehrenberg, 1847a

5(6)Ba. Petalospyris triceros (Ehrenberg) (Plate 2B, Figures 5,6)

Ceratospyris triceros Ehrenberg, 1873 , p. $220 ; 1875$, pl. 21 , fig. 5 . Tristylospyris triceros (Ehrenberg), Haeckel, 1887, p. 1033; Riedel, 1959 , p. 292, pl. 1, figs. 7, 8; Riedel and Sanfilippo, 1971, p. 1592, pl. 3A, figs. 11, 12 .

Dorcadospyris triceros (Ehrenberg) Moore, 1971, p. 739, pl. 6, figs. 1-3.

Petalospyris triceros (Ehrenberg) group, Petrushevskaya and Kozlova (1972), p. 532, pl, 40, fig. 9.

5(7). Family THEOPERIIDAE Haeckel, 1881, emend. Riedel, $1967 \mathrm{~b}$.

5(7)A. Genus ANTHOCYRTOMA Haeckel, 1887 5(7)Aa, Anthocyrtoma sp.

(Plate 1E, Figures 5-9, Plate 2A, Figure 9)

See Riedel and Sanfilippo, 1971, p. 524, pl. 6, figs. 2-4.

5(7)B. Genus ARTOPHORMIS Haeckel, 1881

5(7)Ba. Artophormis gracilis Riedel (Plate 2C, Figures 1-5)

Artophormis gracilis Riedel, 1959, p. 300, pl. 2, figs. 12, 13. Cyrtophormis gracilis (Riedel), Petrushevskaya and Kozlova, 1972, p. 547 , pl. 28 , figs. $13-15$. 
Remarks: Petrushevskaya and Kozlova's (1972) generic assignment for this species may be somewhat more correct than Riedel's (1959) because of the straight sided fourth segment of $C$. armata (type species of Cyrtophormis). However, this criterion would not apply to $A$. barbadensis in which the fourth segment is conical, or A. dominasinesis in which it is constricted distally. Presumably Riedel (1959) placed this species in the genus Artophormis because of the ribs sometimes present in the fourth segment. However, since these are not always discernible, his generic assignment is also questionable. It may be that the two genera should be synonymized and emended, in which case Artophormis Haeckel, 1881 (type species $A$. horrida Haeckel, 1887 , pl. 75, fig. 2) would be the senior synonym.

5(7)C. Genus BURYELLA Foreman, 1973

\section{5(7)Ca. Buryella clinata Foreman} (Plate 4, Figure 1)

Lithocampe sp. Nigrini in Cita, Nigrini and Gartner, 1970, pl. 2, fig. M.

Lithocampium sp. Riedel and Sanfilippo, 1970, p. 533, pl. 10, fig. 8.

Buryella clinata Foreman, 1973, p. 433, pl. 8, figs. 1-3; pl. 9, fig. 19.

5(7)D. Genus CALOCYCLAS Ehrenberg, 1847b

See Foreman, 1973b, p. 433.

\section{5(7)Da. Calocyclas hispida (Ehrenberg)}

(Plate 1F, Figures 5-8)

Anthocyrtis hispida Ehrenberg, 1873, p. 216;1875, pl. 8, fig. 2.

Cycladophora hispida (Ehrenberg), Riedel and Sanfilippo, 1970, p. 529 , pl. 10 , fig. 9 , 1971 , p. 1593 , pl. 3B, figs. 10 , 11; Moore, 1971 , p. 741 , pl. 4, figs. $6,7$.

\section{5(7)Db. Calocyclas turris Ehrenberg} (Plate 2C, Figure 6)

Calocyclas turris Ehrenberg, 1873, p. 218; 1875, p. 66, pl. 18, fig. 7. Cycladophora turris (Ehrenberg), Riedel and Sanfilippo, 1970, p. 529 , pl. 13 , figs. 3,4 .

\section{5(7)E. Genus CALOCYCLOMA Haeckel, 1887}

\section{5(7)Ea. Calocycloma ampulla (Ehrenberg)} (Plate 1F, Figures 1-4)

Eucyrtidium ampulla Ehrenberg, 1854b, pl. 36, figs. 15a-c; 1873, p. $225 ; 1875$, p. 70 , pl. 10 , figs. 11,12 a-b.

Calocycloma (?) ampulla (Ehrenberg), Riedel and Sanfilippo, 1970, p. 524 , pl. 6 , fig. 1 .

Calocycloma ampulla (Ehrenberg), Foreman, 1973, p. 434, pl. 1, figs. 1-5; pl. 9, fig. 20.

5(7)F. Genus CYCLAMPTERIUM Haeckel, 1887

5(7)Fa. Cyclampterium pegetrum Sanfilippo and Riedel (Plate 2C, Figures 7, 8)

Cyclampterium (?) pegetrum Sanfilippo and Riedel, 1970, p. 456, pl. 2, figs. 8-10; Petrushevskaya and Kozlova, 1972, p. 548, pl. 34 , figs. 7,8 .

Remarks: The two forms distinguished by Petrushevskaya and Kozlova (1972) have not been separated herein.

\section{5(7)G. Genus EUSYRINGIUM Haeckel 1881}

5(7)Ga. Eusyringium fistuligerum (Ehrenberg)

(Plate 1F, Figures 9-12, Plate 2C, Figure 9)

Eucyrtidium fistuligerum Ehrenberg, 1873, p. 229; 1875, p. 70, pl. 9 , fig. 3.

Eusyringium fistuligerum (Ehrenberg), Riedel, 1957a, p. 94, pl. 4, fig. 8; Riedel and Sanfilippo, 1970, p. 527, pl. 8, figs. 8, 9.
Remarks: The two morphological extremes of this species noted by Moore (1971) are also present in the Leg 23 material (Plate 1F, Figures 9 and 10). Petrushevskaya and Kozlova (1972) call the smaller, thinner walled form Eusyringium tubulus (Ehrenberg) and indeed a taxonomic distinction seems warranted. However, in the range charts presented herein both forms have been considered as $E$. fistuligerum.

\section{5(7)Gb. Eusyringium lagena (Ehrenberg) (?) (Plate 1F, Figures 13, 14)}

Eusyringium lagena (Ehrenberg)(?), Riedel and Sanfilippo, 1970, p. 527, pl. 8, figs. 5-7; Foreman, 1973, p. 435, pl. 11, figs. 4, 5.

5(7)H. Genus LAMPTONIUM Haeckel, 1887

See Foreman, 1973, p. 435.

5(7)Ha. Lamptonium fabaeforme (?) chaunothorax Riedel and Sanfilippo

(Plate 1G, Figure 1)

Lamptonium (?) fabaeforme (?) chaunothorax Riedel and Sanfilippo, 1970, p. 524, pl. 5, figs. 8, 9 .

\section{$5(7) H b$. Lamptonium fabaeforme (?) constrictum Riedel and Sanfilippo \\ (Plate 1G, Figure 2)}

Lamptonium (?) fabaeforme (?) constrictum Riedel and Sanfilippo, 1970, p. 523, pl. 5, fig. 7.

5(7)Hc. Lamptonium fabaeforme fabeforme (Krasheninnikov) (?) (Plate 1G, Figure 3)

[?] Cyrtocalpis fabaeformis Krasheninnikov, 1960, p. 296, pl. 3, fig. 11.

Lamptonium (?) fabaeforme fabaeforme (Krasheninnikov)(?), Riedel and Sanfilippo, 1970, p. 523, pl. 5, fig. 6.

5(7)I. Genus LITHOCHYTRIS Ehrenberg, 1847a

5(7)Ia. Lithochytris archaea Riedel and Sanfilippo (Plate 1G, Figures 7 and 8)

Lithochytris archaea Riedel and Sanfilippo, 1970, p. 528, pl. 9, fig. 7.

\section{5(7)Ib. Lithochytris vespertilio Ehrenberg} (Plate 1G, Figures 4-6)

Lithochytris vespertilio Ehrenberg, 1873, p. 239; 1875, pl. 4, fig. 10; Riedel and Sanfilippo, 1970, p. 528, pl. 9, figs. 5, 6.

\section{5(7)J. Genus LOPHOCYRTIS Haeckel, 1887 \\ 5(7)Ja. Lophocyrtis (?) jacchia (Ehrenberg) (Plate 2C, Figure 10)}

Thyrsocyrtis jacchia, Ehrenberg, 1873, p. $261 ; 1875$, pl. 12 , fig. 7 . Lophocyrtis (?) jacchia (Ehrenberg), Riedel and Sanfilippo, 1970, p. 530 , 1971, pl. 3C, fig. 4 (non fig. 5); Moore, 1971, p. 742, pl. 8 , figs. 4 and 7 .

\section{5(7)K. Genus LYCHNOCANOMA Haeckel, 1887}

See Foreman, 1973, p. 437.

\section{5(7)Ka. Lychnocanoma amphitrite Foreman} (Plate 2D, Figures 2, 3)

Lychnocanoma amphitrite Foreman, 1973, p.437, pl. 11, fig. 10. 
5(7)Kb. Lychnocanoma babylonis (Clark and Campbell) group (Plate 1G, Figures 9-14, Plate 2D, Figure 4)

Dictyophimus babylonis Clark and Campbell, 1942, p. 67, pl. 9, figs. 32,36 .

Sethochytris babylonis (Clark and Campbell) group, Riedel and Sanfilippo, 1970, p. 528, pl. 9, figs. 1-3.

Remarks: The suggestion by Petrushevskaya and Kozlova (1972) that this species has an affinity to Lithochytris tripodium Ehrenberg (1873, p. 239; 1875, pl. 4, fig. 11) is rejected because Ehrenberg's illustration clearly shows a 3 -segmented form, whereas $L$. babylonis is 2-segmented.

5(7)Kc. Lychnocanoma bellum (Clark and Campbell) (Plate 1H, Figures 1-3, Plate 2D, Figure 1)

Lychnocanium bellum Clark and Campbell, 1942, p. 72, pl. 9, figs. 35, 39; Riedel and Sanfilippo, 1970, p. 529, pl. 10, fig. 5 .

Lychnocanium sp. Riedel, 1957 b, p. 259, pl. 63, fig. 5 .

Lychnocanoma bellum (Clark and Campbell), Foreman, 1973, p. 437 , pl. 1 , fig. 17 ; pl. 11 , fig. 9 .

5(7)Kd. Lychnocanoma trifolium (Riedel and Sanfilippo)

Lychnocanium trifolium Riedel and Sanfilippo, 1971, p. 1595, pl. 3B, fig. 12; pl. 8, figs. 2, 3 .

\section{5(7)L. Genus PHORMOCYRTIS Haeckel, 1887}

See Foreman, 1973, p. 438.

\section{5(7)La. Phormocyrtis embolum (Ehrenberg) (Plate 1H, Figures 4, 5)}

Eucyrtidium embolum Ehrenberg, 1873, p. 228; 1875, pl. 10, fig. 5 . Phormocyrtis embolum (Ehrenberg), Riedel, 1957a, p. 88, pl. 3, figs. 6,7 .

\section{5(7)Lb. Phormocyrtis striata striata Brandt (Plate 1F, Figures 15-18)}

Phormocyrtis striata Brandt in Wetzel, 1935, p. 55, pl. 9, fig. 12; Riedel and Sanfilippo, 1970, p. 532, pl. 10, fig. 7; Foreman, 1973 , p. 438 , pl. 7 , figs. 5, 6,9 .

Eusyringium striata (Brandt), Petrushevskaya and Kozlova, 1972, p. 549 , pl. 32 figs. $1,2$.

Remarks: Foreman (1973) noted that this species is probably not closely related to the type of species of Phormocyrtis. However, neither does Eusyringium seem to be the correct genus for this species as has been suggested by Petrushevskaya and Kozlova (1972). The present author has never observed the final segment of $P$. striata striata to be prolonged into a tube in the way that it is illustrated for E. conosiphon (type species of Eusyringium) or as has been observed in $E$. fistuligerum. Until it is possible to place this species in a genus in accordance with its phylogeny, as has been done in the case of $E$. fistuligerum and $E$. lagena, it is advisable to let it remain in the genus Phormocyrtis.

\section{5(7)M. Genus PTEROCANIUM Ehrenberg, 1947a}

\section{5(7)Ma. Pterocanium prismatium Riedel}

Pterocanium prismatium Riedel, 1957a, p. 87, pl. 3, figs. 4-5; Riedel and Sanfilippo, 1970, p. 529.

Remarks: This distinctive and usually common species is curiously absent from Site 223 material despite quite good preservation in the interval where one would expect to find it.

\section{5(7)N. Genus RHOPALOCANIUM Ehrenberg, 1847 \\ 5(7)Na. Rhopalocanium ornatum Ehrenberg (Plate 1H, Figures 6-10)}

Rhopalocanium ornatum Ehrenberg, 1847b, fig. 3; 1854b, pl. 36, fig. $9 ; 1873$, p. $256 ; 1875$, p. 82 , pl. 17 , fig. 8 . Foreman, 1973 , p. 439 , pl. 2 , figs. $8-10$; pl. 12 , fig. 3 .

5(7)O. Genus STICHOCORYS Haeckel, 1881

5(7)Oa. Stichocorys delmontensis (Campbell and Clark) (Plate 7, Figure 4)
Eucyrtidium delmontense, Campbell and Clark, 1944, p. 56, pl. 7, figs. 19, 20; Riedel, 1952, p. 8, pl. 1, fig. 3; Riedel, 1957a, p. 93.

Stichocorys delmontensis (Campbell and Clark), Riedel and Sanfilippo, 1970 , p. 530 , pl. 14 , fig. $6 ; 1971$, pl. 1F, figs. $5-7$, pl. 2E, figs. 10,11 .

\section{5(7)Ob. Stichocorys peregrina (Riedel) (Plate 7, Figure 5)}

Eucyrtidium elongatum peregrinum Riedel, 1953, p. 812, pl. 85, fig. 2.

\section{5(7)P. Genus THEOCORYS Haeckel, 1881}

See Riedel and Sanfilippo, 1970, p. 530; and Foreman, 1973, p. 439.

\section{5(7)Pa. Theocorys anapographa Riedel and Sanfilippo} (Plate 1H, Figure 11)

Theocorys anapographa Riedel and Sanfilippo, 1970, p. 530, pl. 10, fig. 4; Foreman, 1973, pl. 5, figs. 9, 10.

\section{$5(7) \mathrm{Pb}$. Theocorys (?) spongoconum Kling (Plate 2D, Figure 5)}

Theocorys spongoconus Kling, 1971, p. 1087, pl. 5, fig. 6 . Theocorys spongoconum Kling, Riedel and Sanfilippo, 1971, pl. 2F, fig. 4; pl. 3C, figs. 3; Foreman, 1973.

5(7)Q. Genus THEOCOTYLE Riedel and Sanfilippo, 1970

Subgenus THEOCOTYLE Riedel and Sanfilippo

5(7)Qa. Theocotyle (Theocotyle) cryptocephala (?) conica Foreman

(Plate 1I, Figure 4)

Theocotyle (Theocotyle) cryptocephala (?) conica Foreman, 1973, p. 440 , pl. 4 , fig. 11 ; pl. 12, figs. 19, 20.

\section{5(7)Qb. Theocotyle (Theocotyle) cryptocephala} cryptocephala (Ehrenberg) (?)

(Plate 1I, Figures 2, 3)

[?] Eucyrtidium cryptocephalum Ehrenberg, 1873, p. 227; 1875, p. 70 , pl. 11, fig. 11 .

Theocotyle cryptocephala cryptocephala (Ehrenberg) (?), Riedel and Sanfilippo, 1970, p. 525, pl. 6, figs. 7, 8; Foreman, 1973, p. 440 , pl. 4, figs. 6 , 7; pl. 12, fig. 18.

\section{5(7)Qc. Theocotyle (Theocotyle) cryptocephala (?) nigriniae Riedel and Sanfilippo (Plate 1I, Figure 1)}

Theocorys sp. Nigrini in Cita, Nigrini, and Gartner, 1970, p. 404, pl. 2 , fig. $\mathbf{L}$.

Theocotyle cryptocephala (?) nigriniae Riedel and Sanfilippo, 1970, p. 525, pl. 6, figs. 5, 6; Foreman, 1973, p. 440, pl. 4, figs. 1-5; pl. 12 , fig. 17 .

Subgenus THEOCOTYLISSA Foreman, 1973

5(7)Qd. Theocotyle (Theocotylissa) ficus (Ehrenberg) (Plate 1I, Figures 5-8)

Eucyrtidium ficus Ehrenberg, 1873 , p. $228 ; 1875$, p. 70 , pl. 11, fig. 19.

Theocotyle (?) ficus (Ehrenberg), Riedel and Sanfilippo, 1970, p. 525 , pl. 7, figs. 3-5; Foreman, 1973, p. 441, pl. 4, figs. 16-20.

\section{5(7)R. Genus THYRSOCYRTIS Ehrenberg, 1847b}

\section{5(7)Ra. Thyrsocyrtis bromia Ehrenberg} (Plate 2D, Figure 6)

Thyrsocyrtis bromia Ehrenberg, 1873, p. $260 ; 1875$, p. 84, p1. 12, fig. 2; Riedel and Sanfilippo,1970, p. 526; 1971, p. 1596, pl. 8, fig. 6 ; Moore, 1971, p. 740, pl. 5, figs. 1-3. 
5(7)Rb. Thyrsocyrtis hirsuta hirsuta (Krasheninnikov) (Plate 1J, Figure 1)

Podocyrtis hirsutus Krasheninnikov, 1960, p. 300, pl. 3, fig. 16.

Thyrsocyrtis hirsuta hirsuta (Krasheninnikov), Riedel and Sanfilippo, 1970, p. 526, pl. 7, fig. 9; Foreman, 1973, p. 441, pl. 3, fig. $3-8$; pl. 12, fig. 15 .

Remarks: Petrushevskaya and Kozlova (1972) place this species in synonomy with Podocyrtis argulus Ehrenberg, 1873 (and retain the specific name argulus). However, Ehrenberg's illustration (1875, pl. 16, fig. 2) shows a form which is conical in section, where as $T$. hirsuta hirsuta is distinctly subcylindrical. Furthermore, the abdomen of Ehrenberg's species is longer than the thorax, whereas, in $T$. hirsuta hirsuta the thorax and abdomen are approximately equal in length. Nevertheless, considering the age of the topotypic material it certainly seems likely that these differences could be attributed to poor illustration by Ehrenberg. Without examining such material, the present author must defer judgment.

\section{5(7)Rc. Thyrsocyrtis hirsuta robusta Riedel and Sanfilippo} (Plate 1J, Figure 2)

Thyrsocyrtis hirsuta robusta Riedel and Sanfilippo, 1970, p. 526, pl. 8, fig. 1; Foreman, 1973, p. 442, pl. 3, fig. 17.

\section{5(7)Rd. Thyrsocyrtis hirsuta tensa Foreman (Plate 1J, Figures 3, 4)}

Thyrsocyrtis hirsuta hirsuta (Krasheninnikov), Riedel and Sanfilippo, 1970, p. 526, pl. 7, fig. 8.

Thyrsocyrtis hirsuta tensa Foreman, 1973, p. 442, pl. 3, figs. 13-16; pl. 12, fig. 8 .

5(7)Re. Thyrsocyrtis rhizodon Ehrenberg
(Plate 1I, Figures 9-13, Plate 2D, Figure 7)

Thyrsocyrtis rhizodon Ehrenberg, 1873, p. 262; 1875, p. 94, pl. 12, fig. 1; Riedel and Sanfilippo, 1970, p. 525, pl. 7, figs. 6, 7.

5(7)Rf. Thyrsocyrtis tetracantha (Ehrenberg) (Plate 2E, Figure 2)

Podocyrtis tetracantha Ehrenberg, 1873, p. $254 ; 1875$, p. 82, pl. 13, fig. 2.

Thyrsocyrtis tetracantha (Ehrenberg), Riedel and Sanfilippo, 1970, p. $527 ; 1971$, p. 1596.

\section{5(7)Rg. Thyrsocyrtis triacantha (Ehrenberg)}

(Plate 1J, Figures 5-7, Plate 2E, Figure 1)

Podocyrtis triacantha Ehrenberg, 1873, p. $254 ; 1875$, p. 82, pl. 13, fig. 4.

Thyrsocyrtis triacantha (Ehrenberg), Riedel and Sanfilippo, 1970, p. 526, pl. 8, figs. 2, 3; 1971, p. 1596, pl. 3C, fig. 7; Foreman, 1973, p. 442, pl. 12, figs. 9-11.

\section{5(8). Family PTEROCOR YTHIDAE Haeckel, 1881, emend. Moore, 1972 \\ 5(8)A. Genus CALOCYLETTA Haeckel, 1887 \\ 5(8)Aa. Calocycletta virginis (Haeckel) sens. lat. (Plate 2E, Figure 3, 4)}

Calocyclas virginis Haeckel, 1887, p. 1381, pl. 74, fig. 4; Riedel, 1959 , p. 295 , pl. 2 , fig. 8 .

Calocycletta virginis (Haeckel), Riedel and Sanfilippo, 1970, p. 535, pl. 14, fig. 10.

Remarks: Moore $(1971,1972)$ has described a number of forms closely related to $C$. virginis. For the most part these species are rare, and identification depends upon the character of the abdominal termination. The present author was unable to distinguish Moore's species in Leg 23 material and so all forms of this general type have been considered as $C$. virginis sens. lat.

Petrushevskaya and Kozlova (1972) recognize two species of this general form, Calocycletta virginis and $C$. veneris, but their intentions are not at all clear. In the synonomy of their $C$. virginis sens. str. they include Riedel and Sanfilippo's (1971) illustrations, plate $2 \mathrm{H}$, figures $8-11$. These specimens are from the $C$. virginis
Zone (Miocene), but Petrushevskaya and Kozlova clearly state that their $C$. virginis is Eocene, not Miocene, and suggest that the zonal name be changed to $C$. veneris. Furthermore, in the remarks on $C$. veneris they refer to "forms similar to C. virginis (Riedel and Sanfilippo, [1971] , pl. 2H, figs. 8-11). It may be that typographical errors have caused this confusion and, until the matter is resolved, forms of this general type are referred to as $C$. virginis sens. lat. and the zonal name $C$. virginis is retained.

\section{5(8)B. Genus PODOCYRTIS Ehrenberg, 1847}

Subgenus PODOCYRTIS Ehrenberg

See Podocyrtis Ehrenberg, Riedel and Sanfilippo, 1970, p. 533.

\section{5(8)Ba. Podocyrtis (Podocyrtis) ampla fasciolata Nigrini $n$. subsp.}

(Plate 1K, Figures 1, 2, Plate 4, Figures 2, 3)

Description: Shell thick-walled, smooth. Cephalis subspherical with numberous subcircular pores, bearing a short, 3-bladed apical horn approximately the same length as the cephalis. Thorax campanulate to almost conical with subcircular pores aligned longitudinally ( 4 to 7 in a row) and distinct ridges between the pore rows; six to eight pores on a half-equator. Lumbar scripture distinct. Abdomen inflated, wider than thorax at its maximum breadth, narrows distally. Subcircular pores, larger than thoracic pores, usually aligned longitudinally ( 3 to 7 in a row) but sometimes irregular; six to eight on a halfequator. Wide poreless peristome usually with a smooth termination, but may show some thickening indicative of incipient feet. Rarely, three spathulate feet present.

Dimensions (based on 20 specimens): Thorax $50 \mu$ to $83 \mu$ long, $65 \mu$ to $100 \mu$ wide (usually $83 \mu$ to $100 \mu$ ). Abdomen $83 \mu$ to $150 \mu$ long, $115 \mu$ to $165 \mu$ wide.

Remarks: In Leg 23 material this subspecies occurs at about the level where one would expect to find P. ampla ampla and it may well be a geographic variant. It is distinguished from the nominate subspecies by having a more distinct lumbar stricture and more inflated abdomen; the shell is generally heavier and smaller, and the apical horn is 3-bladed rather than conical.

\section{5(8)Bb. Podocyrtis (Podocyrtis) diamesa Riedel and Sanfilippo (Plate 1K, Figures 3-5)}

Podocyrtis (Podocyrtis) diamesa Riedel and Sanfilippo, 1970, p. 533 (pars), pl. 12, fig. 4 (non figs. 5 and 6); Sanfilippo and Riedel, 1973, pl. 20, figs. 9, 10; pl. 35, figs. 10, 11.

\section{5(8)Bc. Podocyrtis (Podocyrtis) dorus Sanfilippo and Riedel (Plate 1K, Figure 6)}

Podocyrtis (Podocyrtis) diamesa Riedel and Sanfilippo, 1970, p. 533 (pars), pl. 12, fig. 5.

Podocyrtis (Podocyrtis) dorus Sanfilippo and Riedel, 1973, p. 531, pl. 35 , figs. 12-14.

\section{5(8)Bd. Podocyrtis (Podocyrtis) papalis Ehrenberg} (Plate 1K, Figures 7-10)

Podocyrtis papalis Ehrenberg, 1847 b, fig. 2; 1854b, pl. 36, fig. 23; 1873 , p. 251; Riedel and Sanfilippo, 1970 , p. 533, pl. 11, fig. 1 .

\section{Subgenus LAMPTERIUM Haeckel, 1881}

See Podocyrtis (Lampterium) Haeckel, Riedel and Sanfilippo, 1970 , p. 534.

Petrushevskaya and Kozlova (1972) make this subgenus of Podocyrtis an independent genus.

\section{5(8)Be. Podocyrtis (Lampterium) aphorma Riedel and Sanfilippo \\ (Plate 1K, Figures 11, 12)}

Podocyrtis (Lampterium) aphorma Riedel and Sanfilippo, 1970, p. 534, pl. 11, fig. 2. 
5(8)Bf. Podocyrtis (Lampterium) helenae Nigrini n. sp. (Plate 1L, Figures 9-11; Plate 4, Figures 4, 5)

Description: Shell smooth, quite thick-walled. Cephalis subspherical with many subcircular pores and thorn-like 3-bladed apical horn. Thorax campanulate with subcircular pores either aligned longitudinally ( 5 to 7 in a row) or irregularly arranged, seven to nine on a half-equator. Lumbar stricture distinct. Abdomen elongate, expanded distally with subcircular pores sometimes aligned longitudinally ( 8 to 13 in a row) but of ten irregular, 8 to 12 on a half-equator. Ridges between the longitudinal rows may become sinuous to follow irregularitites in pore arrangement. Peristome rather wide, smooth, poreless with three spathulate feet.

Dimensions (based on 20 specimens): Thorax $50 \mu-65 \mu$ long, $83 \mu-100 \mu$ wide. Abdomen $133 \mu$ to $248 \mu$ long (including peristome and feet), $115 \mu$ to $150 \mu$ wide.

Remarks: This species is apparently an offshoot of Podocyrtis sinuosa. It is distinguished from that species by the shape of the abdomen which is truncate conical rather than inflated and subcylindrical.

\section{5(8)Bg. Podocyrtis (Lampterium) mitra Ehrenberg (Plate 1L, Figures 5, 6)}

Podocyrtis mitra Ehrenberg, 1854b, pl. 36, fig. B20.

Podocyrtis (Lampterium) mitra Ehrenberg, Riedel and Sanfilippo, 1970, p. 534, pl. 11, figs. 5, 6 .

\section{5(8)Bh. Podocyrtis (Lampterium) sinuosa Ehrenberg (?)} (Plate 1L, Figures 1-4)

[?] Podocyrtis sinuosa Ehrenberg, 1873, p. $253 ; 1875$, pl. 15, fig. 5 . Podocyrtis (Lampterium) sinuosa Ehrenberg (?), Riedel and Sanfilippo, 1970, pl. 11, figs. 3, 4 .

\section{5(8)Bi. Podocyrtis (Lampterium) trachodes Riedel and Sanfilippo \\ (Plate 1L, Figures 7, 8)}

Podocyrtis (Lamperium) trachodes Riedel and Sanfilippo, 1970, p. 535 , pl. 11, fig. $7 ;$ pl. 12, fig. 1.

\section{5(8)C. Genus THEOCYRTIS Haeckel, 1887 \\ 5(8)Ca. Theocyrtis tuberosa Riedel (Plate 2E, Figures 5, 6)}

Theocyrtis tuberosa Riedel, 1959, p. 298, pl. 2, figs. 10, 11.

Remarks: Only markedly tuberous specimens, which are very rare in the Leg 23 material, were considered to be $T$. tuberosa. Moore (1971) included both smooth and tuberous forms. Petrushevskaya and Kozlova (1972) recognize several forms (? subspecies) of this species and place them in the genus Calocycletta because of a likely evolutionary link with their Calocycletta virginis. However, until such a link can be documented it seems preferable to base the generic determination on the similarity with the type species of Theocyrtis.

\section{5(9). Family ARTOSTROBIIDAE Riedel, 1967a}

5(9)A. Genus ARTOSTROBIUM Haeckel, 1887

5(9)Aa. Artostrobium doliolum Riedel and Sanfilippo (Plate 7, Figure 6)

Artostrobium doliolum Riedel and Sanfilippo, 1971, p. 1599, pl. $1 \mathrm{H}$, figs. $1-3$; pl. 8 , figs. 14,15 .

\section{5(9)B. Genus PHORMOSTICHOARTUS Campbell, 1951 \\ 5(9)Ba. Phormostichoartus corona (Haeckel) (Plate 7, Figure 7)}

Cyrtophormis corona Haeckel, 1887, p. 1462, pl. 77, fig. 15.

Phormostichoartus corona (Haeckel), Riedel and Sanfilippo, 1971, p. 1600 , pl. 1i, figs. $13-15 ;$ pl. 2 J, figs. 1-5.

Theocamptra corona (Haeckel) group, Petrushevskaya and Kozlova (1972), p. 538, pl. 23, figs. 24, 25.

Remarks: This species is more closely related to the type species of Phormostichoartus (Cyrtophormis cylindrica Haeckel, 1887, p. 1461 , pl. 77 , fig. 17) than to the type species of Theocamptra
(Theocampe collaris Haeckel, 1887 , p. 1425 , pl. 66, fig. 18). Therefore, the generic designation Phormostichoartus is retained.

\section{5(9)C. Genus THEOCAMPE Haeckel, 1887}

5(9)Ca. Theocampe amphora (Haeckel) group

(Plate 1M, Figures 1-5, Plate 2E, Figure 7)

Dictyocephalus amphora Haeckel, 1887, p. 1305, pl. 62, fig. 4 .

Theocampe amphora (Haeckel) group, Foreman, 1973, p. 431, pl. 8, fig. 7, 9-13; pl. 9, fig. 8, 9 .

Remarks: Theocampe urceolus (Haeckel) as described by Foreman (1973) could not be satisfactorily distinguished in Leg 23 material from the Theocampe amphora group. Also included in this group are forms similar to those described by Petrushevskaya and Kozlova (1972) as Theocampe excellens (Ehrenberg) and Theocampe eos (Clark and Campbell).

\section{5(9)Cb. Theocampe armadillo (Ehrenberg) group} (Plate 1M, Figure 6, Plate 2E, Figure 8)

Eucyrtidium armadillo Ehrenberg, 1873, p. $225 ; 1875$, p. 70 , pl. 9 , fig. 10.

Theocampe armadillo (Ehrenberg) group, Riedel and Sanfilippo, 1971 , p. 1601 , pl. $3 \mathrm{E}$, figs. $3-6$.

5(9)Cc. Theocampe mongolfieri (Ehrenberg)

(Plate 1M, Figures 7-10, Plate 2E, Figure 9)

Eucyrtidium mongolfieri Ehrenberg, 1854b, pl. 36, fig. 18, B lower; 1873 , p. $230 ; 1875$, p. 72 , pl. 10 , fig. 3.

Theocampe mongolfieri (Ehrenberg), Burma, 1959, p. 329; Riedel and Sanfilippo, 1970, p. 536, pl. 12, fig. 9; 1971, pl. 3E, fig. 13; Foreman, 1973, p. 432, pl. 8, fig. 1; pl. 9, fig. 17.

\section{5(9)Cd. Theocampe pirum (Ehrenberg)} (Plate 2E, Figure 10)

Eucyrtidium pirum Ehrenberg, 1873, p. $232 ; 1875$, p. 72 , pl. 10, fig. 14.

Theocampe pirum (Ehrenberg), Riedel and Sanfilippo, 1971, pl. 3E, figs. $10,11$.

5(10). Family CANNOBOTRYIDAE Haeckel, 1881, emend. Riedel, 1967

5(10A. Genus ACROBOTRYS Haeckel, 1881

5(10)Aa. Acrobotrys tritubus Riedel (Plate 7, Figure 8)

Acrobotrys tritubus Riedel, 1957a, p. 80, pl. 1, fig. 5 .

\section{5(11). INCERTAE SEDIS}

\section{5(11)A. Genus LOPHOCYRTIS Haeckel, 1887 \\ 5(11)Aa. Lophocyrtis biaurita (Ehrenberg) (Plate 1M, Figures 11-13)}

Eucyrtidium biauritum Ehrenberg, 1873, p. 226; 1875, p. 70, pl. 10 , figs. 7,8 .

Lophocyrtis biaurita (Ehrenberg), Haeckel, 1887, p. 1411. Cita, Nigrini, and Gartner, 1970, p. 404, pl. 2, figs. I-K; Foreman, 1973, pl. 8, figs. 23-26.

\section{5(11)Ba. sp. cf. Lithomitra elizabethae Clark and Campbell}

(Plate 1M, Figures 14-17, Plate 4, Figures 6, 7)

Lithomitra elizabethae Clark and Campbell, 1942, p. 92, pl. 9, fig. 18.

Description: Shell thin-walled, smooth, bullet-shaped. Cephalis small, hemispherical, pored, with a small lateral opening. Three to five post-cephalic segments each having two or three transverse rows of subcircular pores. Pores are also aligned longitudinally. Termination usually ragged, of ten with a ring of small projections as if about to form another segment. Specimens with five post-cephalic segments are apparently complete and have a smooth poreless peristome.

Dimensions (based on 20 specimens): Total length $80 \mu-100 \mu$. Maximum breadth $48 \mu-60 \mu$. 
Remarks: This species apparently belongs to the Artostrobiidae, but its exact taxonomic position is not known.

\section{ACKNOWLEDGMENTS}

Most of the microscope work involved in this study was performed at the Ledgemont Laboratory of the Kennecott Copper Corporation. I am indeed grateful for their hospitality. My thanks go also to my family for making my participation in Leg 23 possible, and to my children for sleeping in the afternoons.

\section{REFERENCES}

Brandt, R., 1935. In Wetzel, O., Die Mikopalaeontologie des Heiligenhafener Kieseltones (Ober-Eozän): Niedersächs. Geol. Ver., Hannover, Jber., v. 27, p. 41-81.

Burma, B. H., 1959. On the status of Theocampe Haeckel, and certain similar genera: Micropaleontology, v. 5 (3), p. 325 .

Campbell, A. S. and Clark, B. L., 1944. Miocene radiolarian faunas from Southern California: Geol. Soc. Am., Spec. Paper 51, vii + 76 p.

Cita, M. B., Nigrini, C., and Gartner, S., 1970. Biostratigraphy. In Peterson, M. N. A., Edgar, N. T., et al., Initial Reports of the Deep Sea Drilling Project, Volume II: Washington (U.S. Government Printing Office), p. 391-411.

Clark, B. L. and Campbell, A. S., 1942. Eocene radiolarian faunas from the Mt. Diablo area, California: Geol. Soc. Am., Spec. Paper 39, vii +112 p.

Dumitrica, P., 1973. Cretaceous and Quaternary Radiolaria in deep sea sediments from the northeast Atlantic Ocean and Mediterranean Sea, DSDP Leg 13; In Ryan, W. B. F., Hsü, K. J., et al., 1973. Initial Reports of the Deep Sea Drilling Project, Volume XIII: Washington (U. S. Government Printing Office), p. 829.

Ehrenberg, C. G., 1847a. Über eine halibiolithische, von Herrn R. Schomburgk entdeckte, vorherrschend aus mikoskopischen Polycystinen gebildete, Gebirgsmasse von Barbados: Kgl. Preuss. Akad. Wiss. Berlin, Ber., Jahre 1846 , p. 382-385.

$1847 \mathrm{~b}$. Uber die mikoskopischen kieselschaligen Polycystinen als mächtige Gebirgsmasse von Barbados und über das Verhältniss der aus mehr als 300 Neuen Arten bestehenden ganz eigenthümlichen Formengruppe jener Felsmasse zu den zetzt lebenden Thieren und zur Kreidebildung. Eine neue Anregung zur Erforschung des Erdlebens: Kgl. Preuss. Akad. Wiss. Berlin, Ber., Jahre 1847 , p. $40-60$.

1854a. Die systematische Characteristik der neuen mikroskopischen Organismen des tiefen Atlantischen Oceans: Kgl. Preuss. Akad. Wiss. Berlin, Ber., Jahre 1854, p. 236-250.

1854b. Mikrogeologie: Leipzig (Voss), xxvii + 374 p., Atlas, 31 p., Fortsetzung (1856) 88 p. +1 p. errata.

1860. Über den Tiefgrund des stillen Oceans zwischen Californien und den Sandwich-Inseln aus bis $15600^{\prime}$ Tiefe nach Lieut. Brooke: Kgl. Preuss. Akad. Wiss. Berlin, Monatsber., Jahre 1860, p. 819-833.

1873. Grössere Felsproben des PolycystinenMergels von Barbados mit weiteren Erläuterungen: $\mathrm{Kgl}$. Preuss. Akad. Wiss. Berlin, Ber., Jahre 1873, p. 213-263.

1875. Fortsetzung der mikrogeologischen Studien als Gesammt-Uebersicht der mikroskopischen Paläontologie gleichartig analysirter Gebirgsarten der Erde, mit specieller Rücksicht auf den Polycystinen-
Mergel von Barbados. Kgl. Akad. Wiss. Berlin, Abh., Jahre 1875 , p. $1-225+1$ p. errata.

Foreman, H. P., 1973. Radiolaria of Leg 10 with systematics and ranges for the families Amphipyndacidae, Artostrobiidae, and Theoperidae. In Worzel, J. L., Bryant, W., et al., Initial Reports of the Deep Sea Drilling Project, Volume X: Washington (U. S. Government Printing Office), p. 407.

Goll, R. M., 1969. Classification and phylogeny of Cenozoic Trissocyclidae (Radiolaria) in the Pacific and Caribbean basins, Part II: J. Paleonotol., v. 43, no. 2, p. 322-339.

Haeckel, E., 1862. Die Radiolarien. (Rhizopoda Radiaria): Berlin (Reimer) xiv $+572 \mathrm{p}$.

1881. Entwurf eines Radiolarien-Systems auf Grund von Studien der Challenger-Radiolarien: Jena. Z. Med. Naturwiss., v. 15 (new ser., v. 8), no. 3, p. 418-472. 1887. Report on the Radiolaria collected by H.M.S. Challenger during the years 1873-76. Rep. Voyage Challenger, Zool., v. 18, clxxxviii +1803 p.

Kling, S. A., 1971. Radiolaria, Leg 6, Deep Sea Drilling Project. In Fischer, A. G., Heezen, B. C., et al., Initial Reports of the Deep Sea Drilling Project, Volume VI: Washington (U. S. Government Printing Office), p. 1069.

Krasheninnikov, V. A., 1960. Nekotorye Radiolyarii Nizhnego i Srednego Eotsena Zapadnogo Predkavkazya: Min. Geol. i Okhr. Nedr SSSR, Vses. Nauch.-Issled. Geol. Neft. Inst., no. 16, p. 271-301.

Moore, T. C., Jr., 1971. Radiolaria. In Tracey, J. I., Jr., Sutton, G.H., et al., Initial Reports of the Deep Sea Drilling Project, Vol. VIII: Washington (U. S. Government Printing Office), p. 727-775.

1972. Mid-Tertiary evolution of the radiolarian genus Calocycletta: Micropaleontology, v. 18, no. 2, pp. 144-152.

Muller, J., 1857. Über die Thalassicollen, Polycystinen und Acanthometren des Mittel meeres: Monatsber. Kgl. Preuss. Akad. Wiss. Berlin, Jahrg. 1856, p. 474-503.

1858. Über die Thalassicollen, Polycystinen und Acanthometren des Mittelmeeres: Kg. Akad. Wiss. Berlin, Abh., Jahre 1858, p. 1-62.

Nigrini, C., 1967. Radiolaria in pelagic sediments from the Indian and Atlantic oceans. Scripps Inst. Oceanog. Univ. Calif. Bull. 11.

1971. Radiolarian zones in the Quaternary of the equatorial Pacific Ocean. In The Micropaleontology of Oceans, Funnel, B. M. and Riedel, W. R. (Eds.): Cambridge (Cambridge University Press), p. 443.

Petrushevskaya, M. G. and Kozlova, G. E., 1972. Radiolaria: Leg 14 Deep Sea Drilling Project. In Hayes, D. E., Pimm, A. C., et al., Initial Reports of the Deep Sea Drilling Project, Volume XIV: Washington (U. S. Government Printing Office), p. 495.

Riedel, W. R., 1952. Tertiary Radiolaria in western Pacific sediments. Goteborgs Kungl Vetensk. -o. Vitterhets Samhalles, Handel., 7 folj., Ser. B., v. 6, no. 3, 22 pages, 2 pl. 1957a. Radiolaria: A preliminary stratigraphy: Rept. Swed. Deep-Sea Exped., v. 6, no. 3, p. 59-96. 1957b. Eocene Radiolaria: U. S. Geol. Surv. Prof. Paper 280G, p. 257-263.

1959. Oligocene and Lower Miocene Radiolaria in tropical Pacific sediments: Micropaleontology, v. 5, no. 3 , p. 285-302.

1967a. Some new families of Radiolaria. Geol. Soc. London, Proc. (1640), p. 148. 
1967b. Subclass Radiolaria. In The Fossil Record, Harland, W. B. et al. (Eds.): London (Geol. Soc. London), p. 291-298.

1971. Systematic classification of polycycstine Radiolaria. In The Micropaleontology of Oceans, Funnel, B. M. and Riedel, W. R. (Eds.): Cambridge (Cambridge Univ. Press), p. 649-661.

Riedel, W. R. and Funnell, B. M., 1964. Tertiary sediment cores and microfossils from the Pacific Ocean floor: Quart. J. Geol. Soc. London, v. 120, p. 305.

Riedel, W. R. and Sanfilippo, A., 1970. Radiolaria, Leg 4, Deep Sea Drilling Project. In Bader, R. G., Gerard, R. D., et al., Initial Reports of the Deep Sea Drilling Project, Volume IV: Washington (U. S. Government Printing Office), p. 503-575.

1971. Cenozoic Radiolaria from the western tropical Pacific, Leg 7. In Winterer, E. L., Riedel, W. R., et al., Initial Reports of the Deep Sea Drilling Project, Volume VII: Washington (U. S. Government Printing Office), p. 1529-1672.

Sanfilippo, A. and Riedel, W. R., 1970. Post-Eocene "closed" theoperid radiolarians: Micropaleontology, v. 16 , no. 4 , pp. 446-462.

1973. Cenozoic Radiolaria (exclusive of theoperids, artostrobiids and amphipyndacids) from the Gulf of Mexico, DSDP Leg 10. In Worzel, J. L., Bryant, W., et al., Initial Reports of the Deep Sea Drilling Project, Volume X: Washington (U.S. Government Printing Office), p. 475.

Sanfilippo, A., Burckle, L. H., Martini, E., and Riedel, W. R., 1973, Radiolarians, diatoms, silicoflagellates and calcareous nannofossils in the Mediterranean Neogene: Micropaleontology, V. 19, no. 2 pp. 209-234.
Sutton, H. J., 1896. Radiolaria; a new genus from Barbados: Am. Mon. Microsc. J., v. 17, no. 194, p. 61-62.

\section{PLATES}

Plate 1(A-M) constitutes a synchronopticon for the zones $T$. mongolfieri through $P$. mitra; Plate 2(A-E) for the zones $T$. bromia through $C$. virignis. In each case the youngest assemblage is at the top of the plate, and the oldest at the bottom. Horizontal rows contain forms in an assemblage of one age and vertical rows show changes in a group through time. All samples are from either Site 219 or 220. The abundance of each morphotype in an assemblage is indicated by: "a" (abundant), "c" (common), "f" (few), "r" (rare) or "+" (very rare).

Plates 3 and 4 show some Early Eocene forms which occur below the $T$. mongolfieri Zone and specimens of species described herein. Slides bearing type specimens will be deposited in the U.S. Museum of Natural History, Washington, D. C.

Plates 5 to 7 comprise those forms used stratigraphically in the study of Site 223 and are Quaternary to Middle Miocene.

Specimens are located according to site, core, section, sample level (in centimeters), slide designation (A, B, C or D) and England finder coordinates. Those slides not containing type specimens, but used in preparing the plates, will be deposited in the permanent radiolarian collection of the Scripps Institution of Oceanography, La Jolla, California. 



\section{PLATE 1A \\ $(X 110)$}

Figure 1

Figure 2

Figure 3

Figure 4

Figure 5

Figure 6

Figure 7

Figure 8

Figure 9

Figure 10

Figure 11
Lithapium anoectum Riedel and Sanfilippo; 219-20-3, 46-8 cm; A-F25/1.

Lithapium anoectum Riedel and Sanfilippo; 220-12, CC; C-O28/0.

Lithapium plegmacantha Riedel and Sanfilippo; 219-20-4, 47-9 cm; A-M47/1.

Lithapium plegmacantha Riedel and Sanfilippo; 219-14-3, 50-2 cm; A-T44/4.

Lithapium plegmacantha Riedel and Sanfilippo; 220-14, CC; A-Q46/0.

Spongatractus balbis Sanfilippo and Riedel; 220-16-2, $47-9 \mathrm{~cm} ; \mathrm{A}-\mathrm{E} 21 / 1$.

Spongatractus balbis Sanfilippo and Riedel; 220-15, CC; A-E33/3.

Spongatractus pachystylus (Ehrenberg); 219-19-1, $47-9 \mathrm{~cm} ; \mathrm{A}-\mathrm{U} 25 / 3$.

Spongatractus pachystylus (Ehrenberg); 219-20-2, $48-50 \mathrm{~cm} ; \mathrm{A}-\mathrm{W} 43 / 0$.

Spongatractus pachystylus (Ehrenberg); 220-12-5, $50-2 \mathrm{~cm}$; B-U29/2.

Spongatractus pachystylus (Ehrenberg); 220-15-5, 51-3 cm; B-E36/0. 


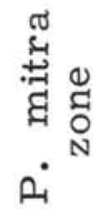

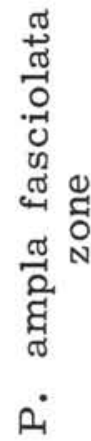

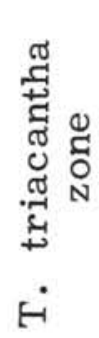

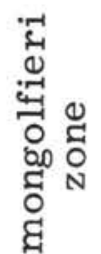
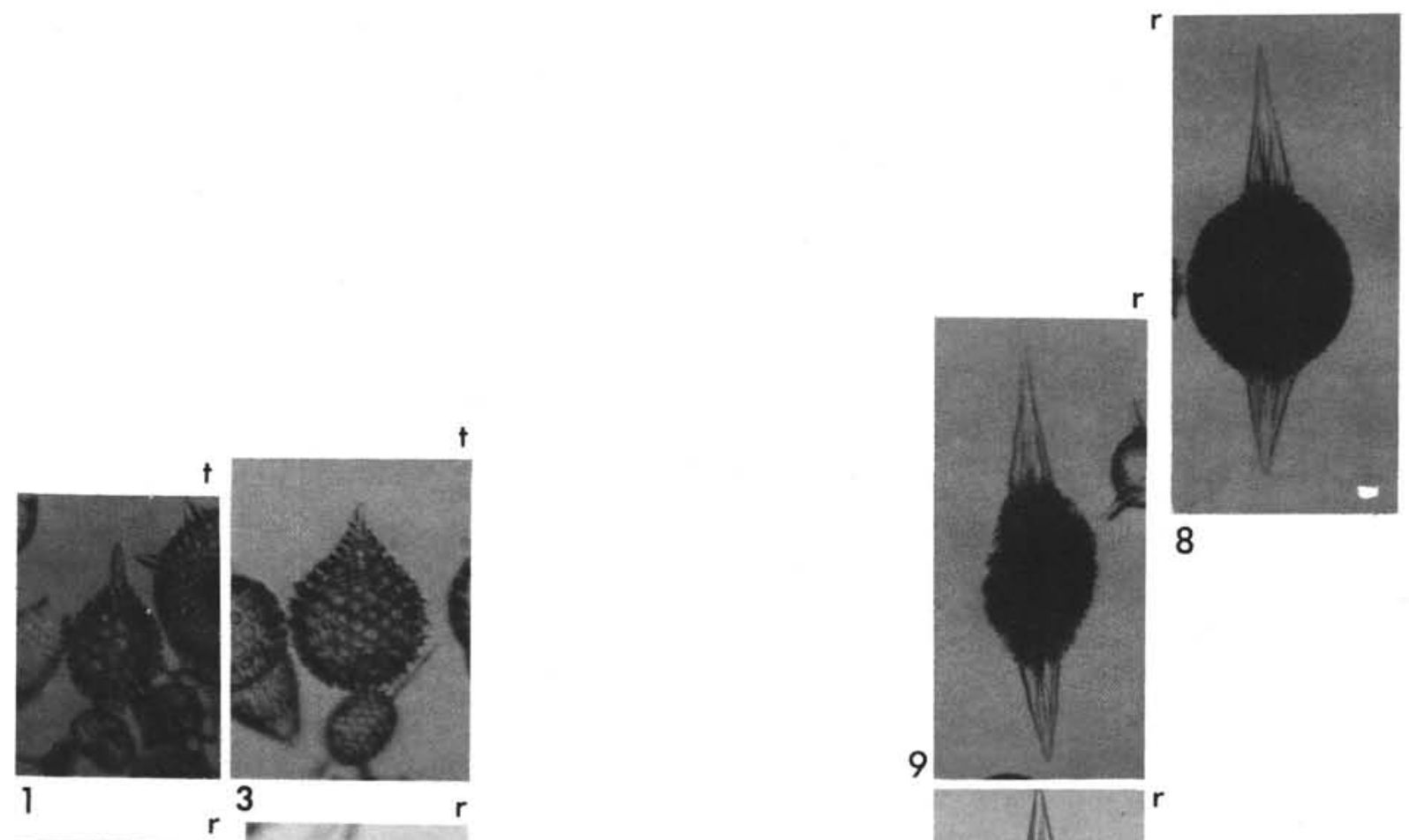

सं
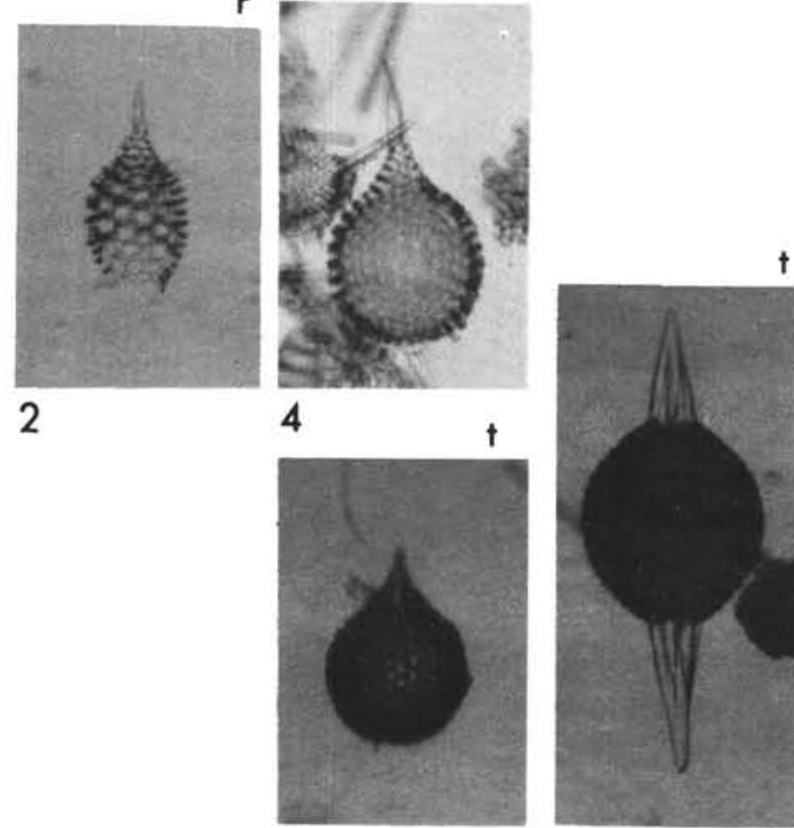

5

6

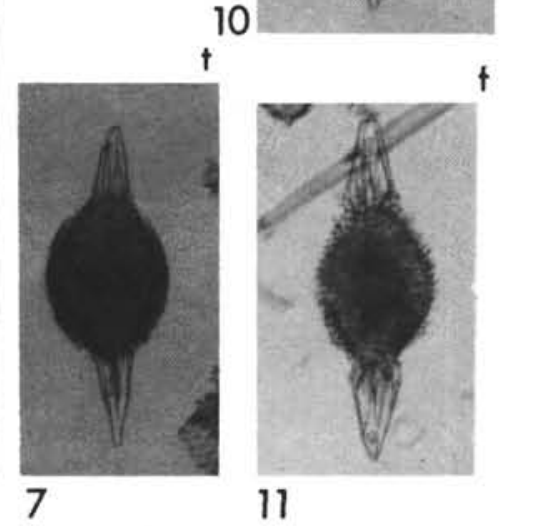




\section{PLATE 1B}

$(\times 110)$

Figure 1 Stylosphaera coronata coronata Ehrenberg;219-20-1, $125-7 \mathrm{~cm} ; \mathrm{A}-\mathrm{T} 32 / 4$.

Figure 2 Stylosphaera coronata coronata Ehrenberg; 220-13, CC; C-Y $41 / 0$.

Figure 3 Stylosphaera coronata coronata Ehrenberg; 220-15, CC; A-E33/0.

Figure $4 \quad$ Stylosphaera coronata sabaca Sanfilippo and Riedel; 220-15, CC; A-L46/1.

Figure $5 \quad$ Heliostylus sp.; 219-20-3, 46-8 cm; A-E20/1.

Figure 6 Heliostylus sp.; 220-12-2, 50-2 cm; B-Y47/1.

Figure 7 Heliostylus sp.; 220-15-2, 50-2 cm; B-Z37/4. 


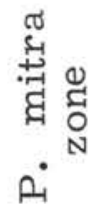

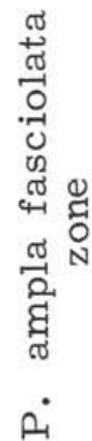

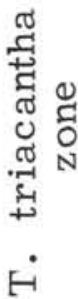

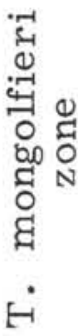
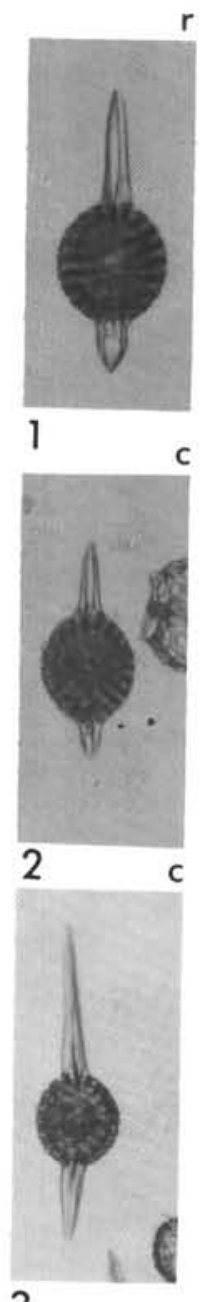

c

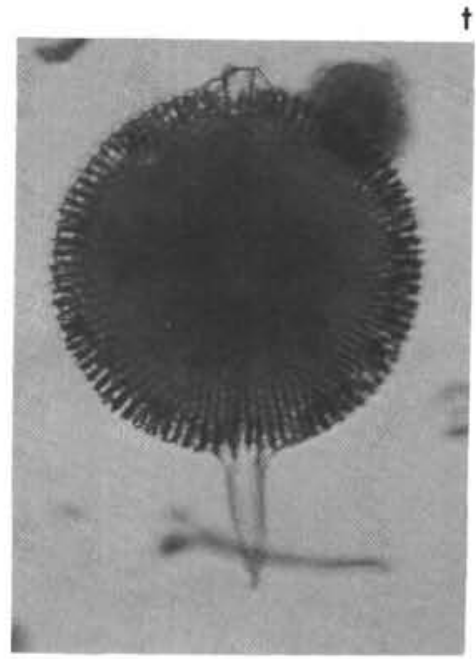

5

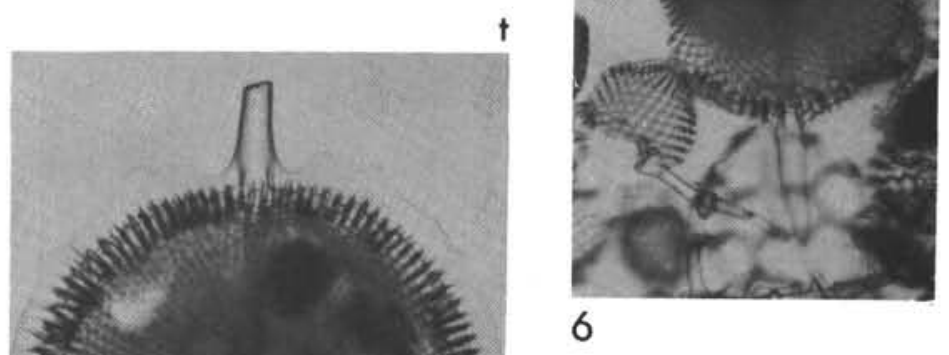




\section{PLATE 1C \\ (X110)}

Figure 1 Periphaena decora Ehrenberg; 219-19-1, 47-9 cm; A-P43/4.

Figure 2 Periphaena decora Ehrenberg; 219-20-3, 46-8 cm; A-J42/4.

Figure 3 Periphaena decora Ehrenberg; 220-13-1, 50-2 cm; A-F28/0.

Figure 4 Periphaena decora Ehrenberg; 220-14-1, 50-2 cm; A-W19/1.

Figure 5 Periphaena decora Ehrenberg; 220-14, CC; A-R17/0.

Figure 6 Periphaena decora Ehrenberg; 220-14-2, 50-2 cm; B-N44/4.

Figure 7 Periphaena delta Sanfilippo and Riedel; 220-15-2, 50-2 cm; A-E37/0.

Figure 8 Periphaena tripyramis tripyramis (Haeckel); 220-15-2, 50-2 cm; A-U52/2. 

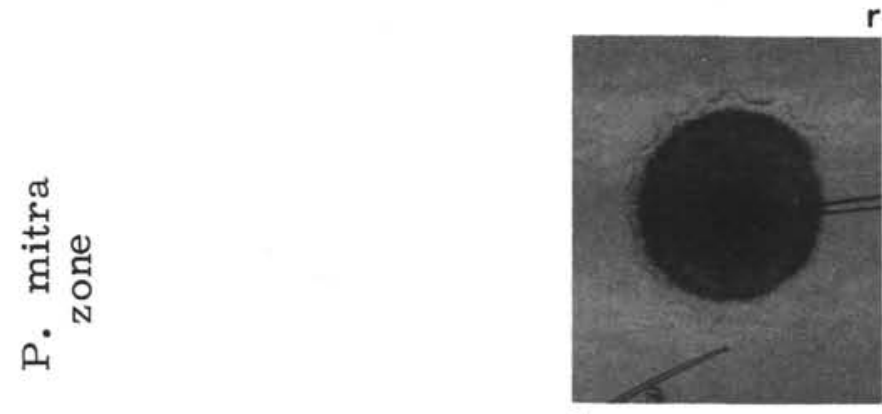

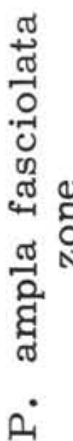
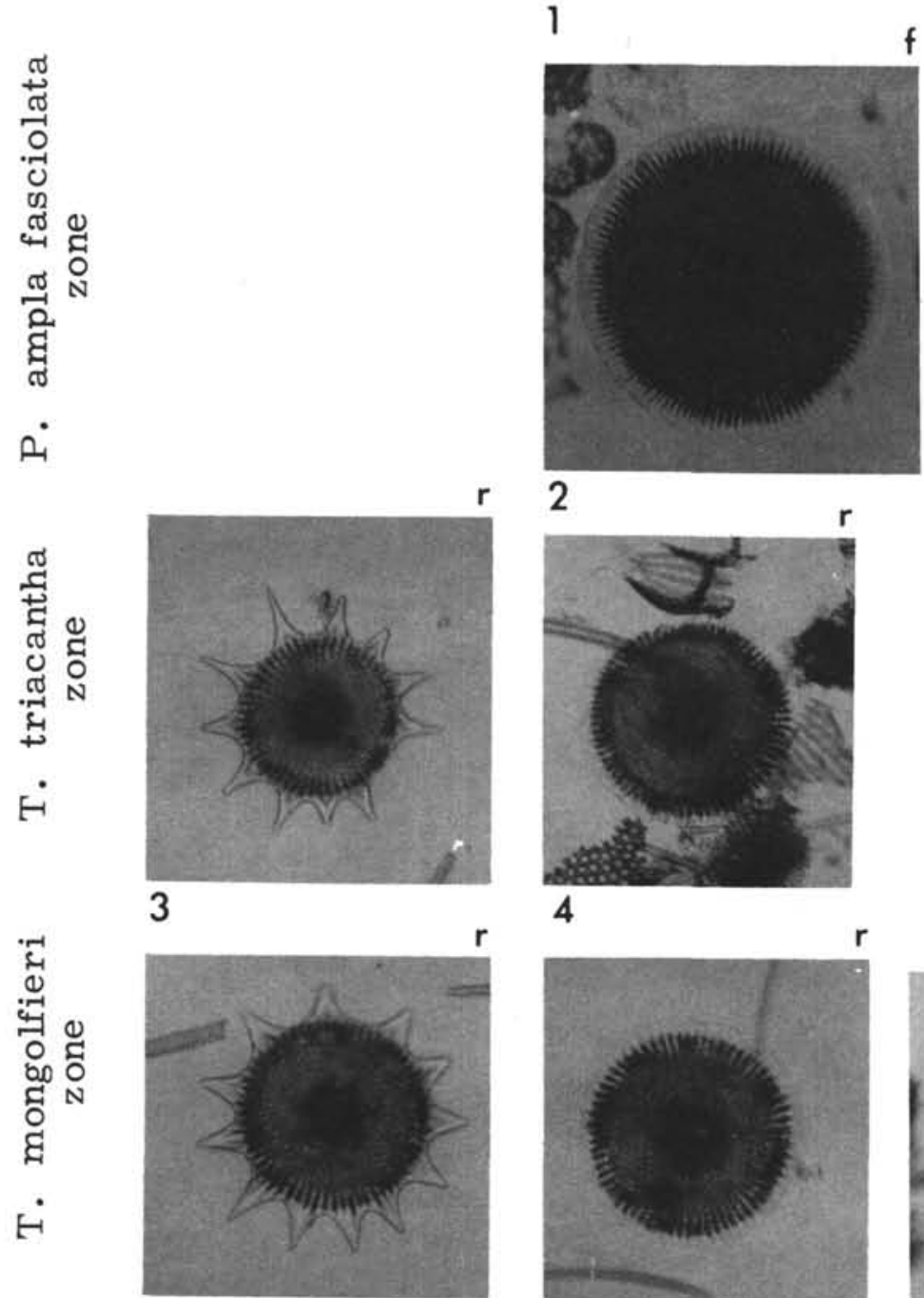

5

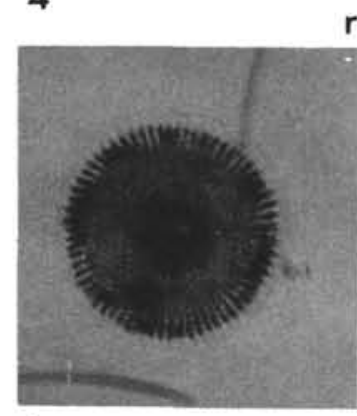

6

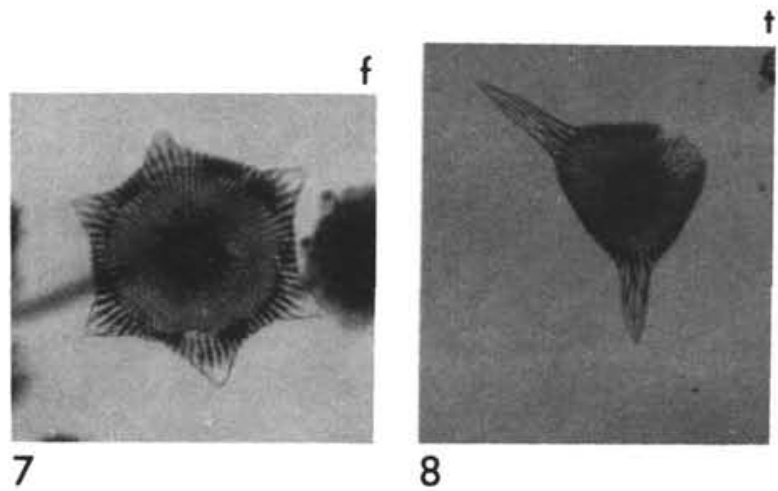




\section{PLATE 1D}

(X110)

Figure $1 \quad$ Periphaena tripyramis triangula (Sutton); 220-13, CC; C-X23/0.

Figure 2 Periphaena tripyramis triangula (Sutton); 220-15-6, $50-2 \mathrm{~cm}$; B-F48/2.

Figure 3 Lithocyclia ocellus Ehrenberg group; 219-19-1, 47-9 cm; A-E48/1.

Figure $4 \quad$ Lithocyclia ocellus Ehrenberg group; 219-20-4, 47-9 $\mathrm{cm} ; \mathrm{A}-\mathrm{U} 31 / 4$.

Figure 5 Lithocyclia ocellus Ehrenberg group;220-12-1,130-2 $\mathrm{cm} ; \mathrm{A}-\mathrm{L} 32 / 0$.

Figure 6 Lithocyclia ocellus Ehrenberg group; 220-15-6, 50-2 $\mathrm{cm} ; \mathrm{A}-\mathrm{R} 46 / 3$.

Figure 7 Amphicraspedum prolixum Sanfilippo and Riedel; 220-15, CC; B-S35/0.

Figure $8 \quad$ Spongodiscus phrix Sanfilippo and Riedel; 220-12, CC; D-W21/1.

Figure 9 Spongodiscus phrix Sanfilippo and Riedel; 220-15-6, 50-2 cm; A-X38/4. 

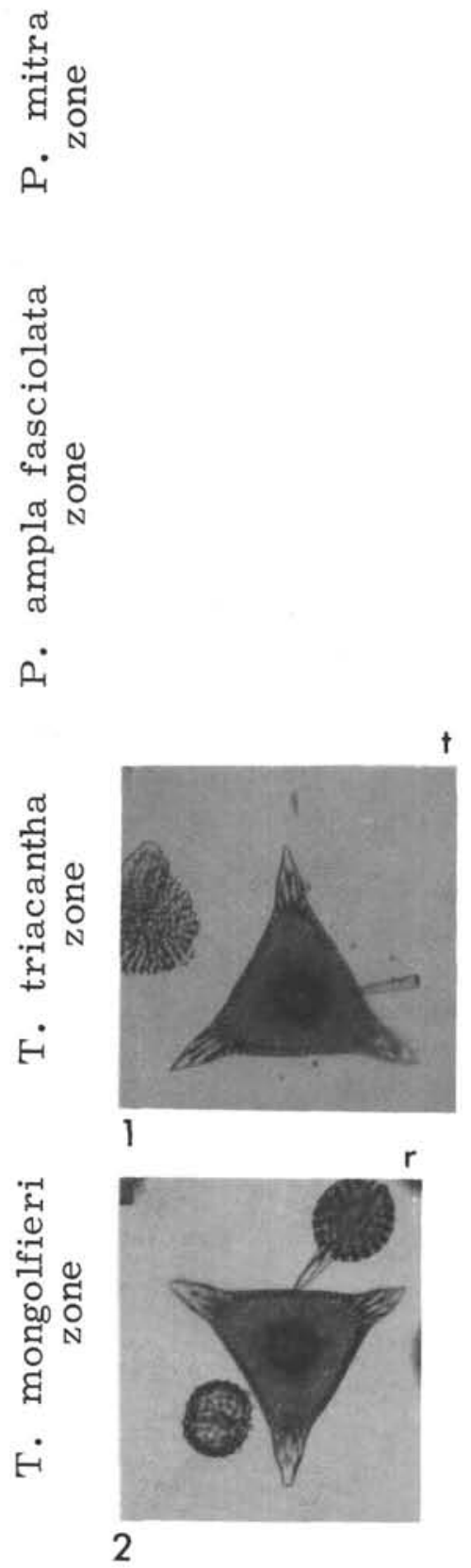

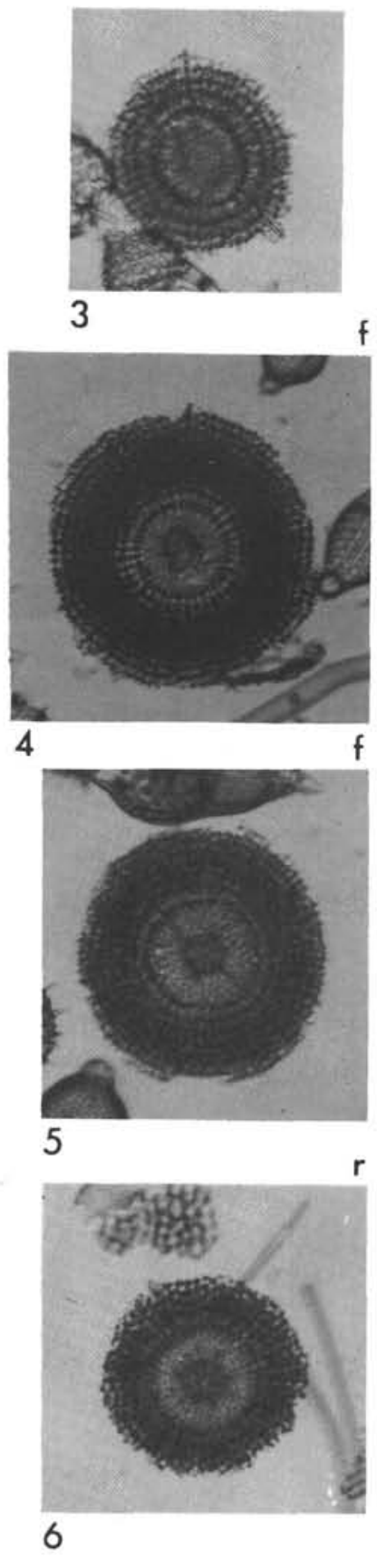

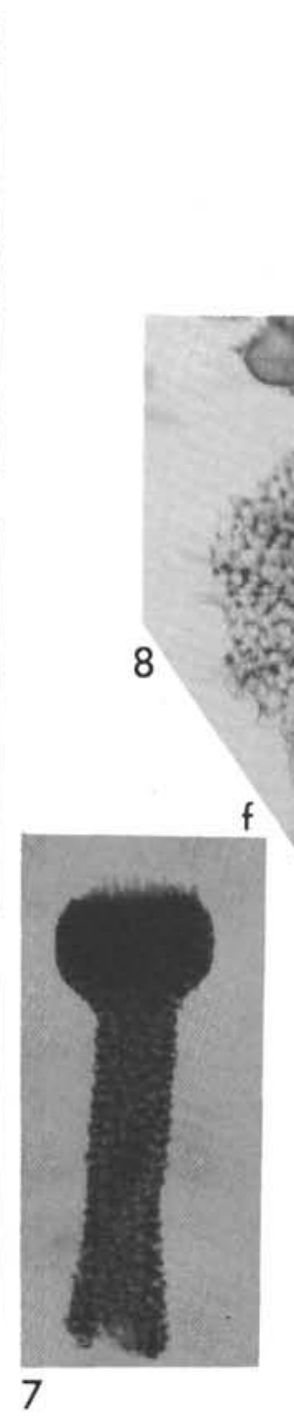




\section{PLATE 1E \\ (X110)}

Figure 1

Figure 2

Figure 3

Figure 4

Figure 5

Figure 6

Figure 7

Figure 8

Figure 9
Spongodiscus rhabdostylus (Ehrenberg); 219-21-2, $48-50 \mathrm{~cm}$; A-H16/4.

Spongodiscus rhabdostylus (Ehrenberg); 220-14-1, $50-2 \mathrm{~cm}$; B-U48/3.

Spongodiscus rhabdostylus (Ehrenberg); 220-15-4, 50-2 cm; B-E48/1.

Stylotrochus quadribrachiatus quadribrachiatus Sanfilippo and Riedel; 220-15-2, 50-2 cm; A-E46/4.

Anthocyrtoma sp.; 219-18, CC; A-K47/2.

Anthocyrtoma sp.; 219-20-4, 47-9 cm; A-M45/0.

Anthocyrtoma sp.; 219-20-4, 47-9 cm; A-S15/1.

Anthocyrtoma sp.; 220-13, CC; C-F16/3.

Anthocyrtoma sp.; 220-15-6, 50-2 cm; A-S20/2 . 


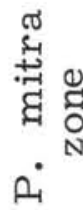

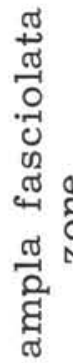

$\dot{0}$

芹

Hi
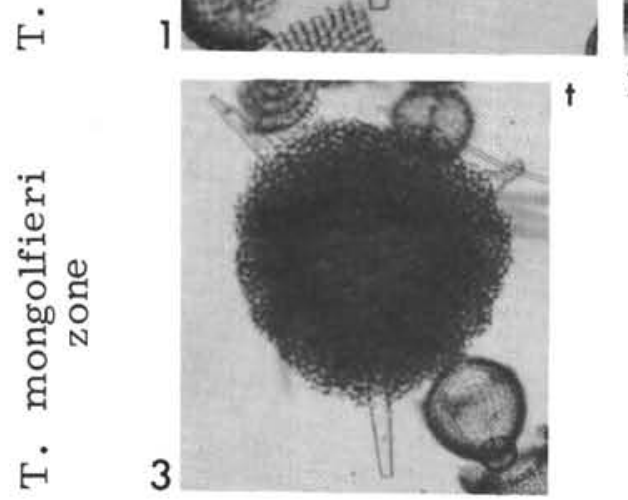

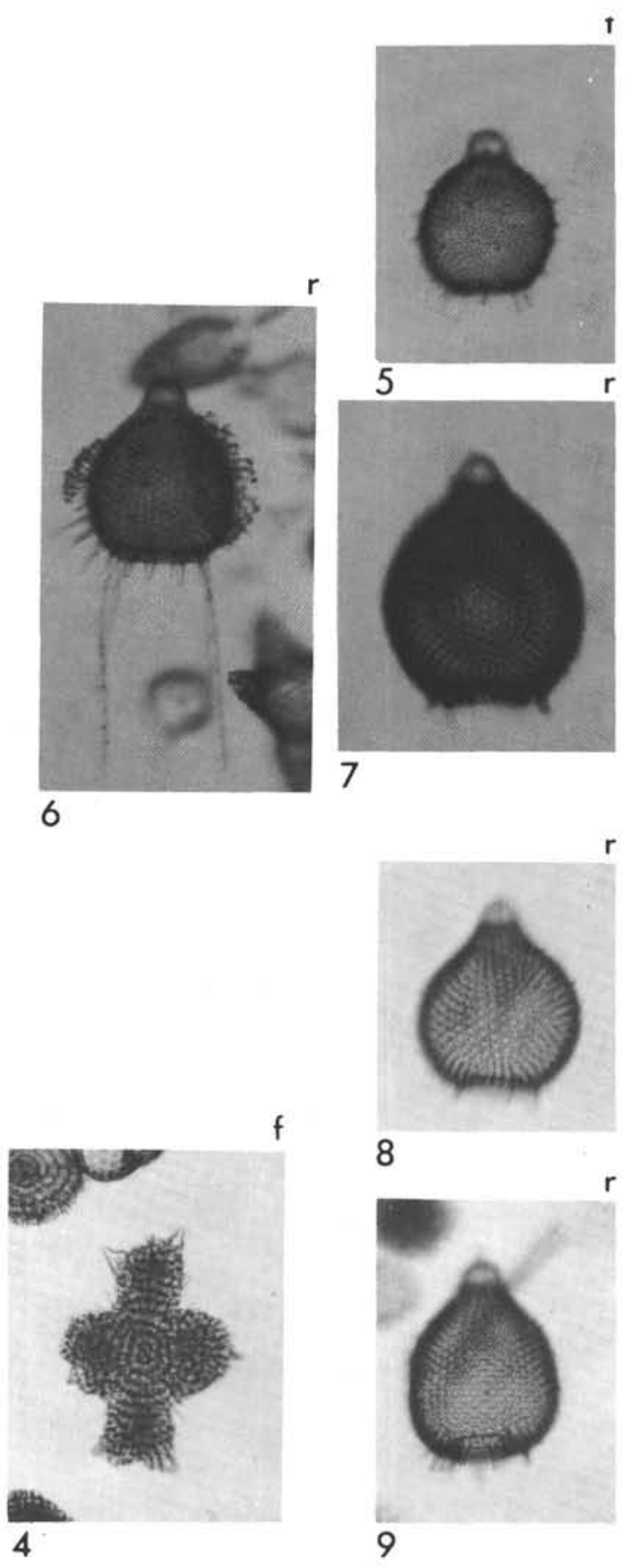


PLATE 1F

(X110)

Figure $1 \quad$ Calocycloma ampulla (Ehrenberg); 219-18-5, 45-7 $\mathrm{cm} ; \mathrm{A}-\mathrm{O} 15 / 0$.

Figure 2 Calocycloma ampulla (Ehrenberg); 219-20-4, 47-9 $\mathrm{cm} ; \mathrm{A}-\mathrm{E} 43 / 4$.

Figure 3 Calocycloma ampulla (Ehrenberg); 220-13, CC; C-P51/0.

Figure 4 Calocycloma ampulla (Ehrenberg); 220-15-2, 50-2 $\mathrm{cm} ; \mathrm{B}-\mathrm{G} 57 / 0$.

Figure $5 \quad$ Calocyclas hispida (Ehrenberg); 219-18, CC; A-R47/2.

Figure $6 \quad$ Calocyclas hispida (Ehrenberg); 219-20-1, 125-7 cm; A-T17/4.

Figure 7 Calocyclas hispida (Ehrenberg); 220-13, CC; C-E42/0.

Figure $8 \quad$ Calocyclas hispida (Ehrenberg); 220-15-6, 50-2 cm; $\mathrm{B}-\mathrm{V} 33 / 3$.

Figure 9 Eusyringium fistuligerum (Ehrenberg); 219-19-5, 47-9 cm; A-M $38 / 0$.

Figure 10 Eusyringium fistuligerum (Ehrenberg); 219-19-1, 47-9 $\mathrm{cm} ; \mathrm{A}-\mathrm{N} 22 / 4$.

Figure 11 Eusyringium fistuligerum (Ehrenberg); 219-20-4, 47-9 $\mathrm{cm} ; \mathrm{A}-\mathrm{P} 33 / 2$

Figure 12 Eusyringium fistuligerum (Ehrenberg); 219-21-1, 47-9 cm; A-R45/0.

Figure 13 Eusyringium lagena (Ehrenberg) (?); 220-13, CC; D-O21/4.

Figure 14 Eusyringium lagena (Ehrenberg) (?); 220-12, CC, C-R24/0.

Figure 15 Phormocyrtis striata striata Brandt; 219-18, CC; A-X50/0.

Figure 16 Phormocyrtis striata striata Brandt; 219-20-4, 47-9 $\mathrm{cm} ; \mathrm{A}-\mathrm{R} 25 / 1$.

Figure 17 Phormocyrtis striata striata Brandt; 220-13-3, 50-2 cm; A-Y19/4.

Figure 18 Phormocyrtis striata striata Brandt; 220-15-4, 50-2 $\mathrm{cm} ; \mathrm{A}-\mathrm{S} 45 / 2$. 


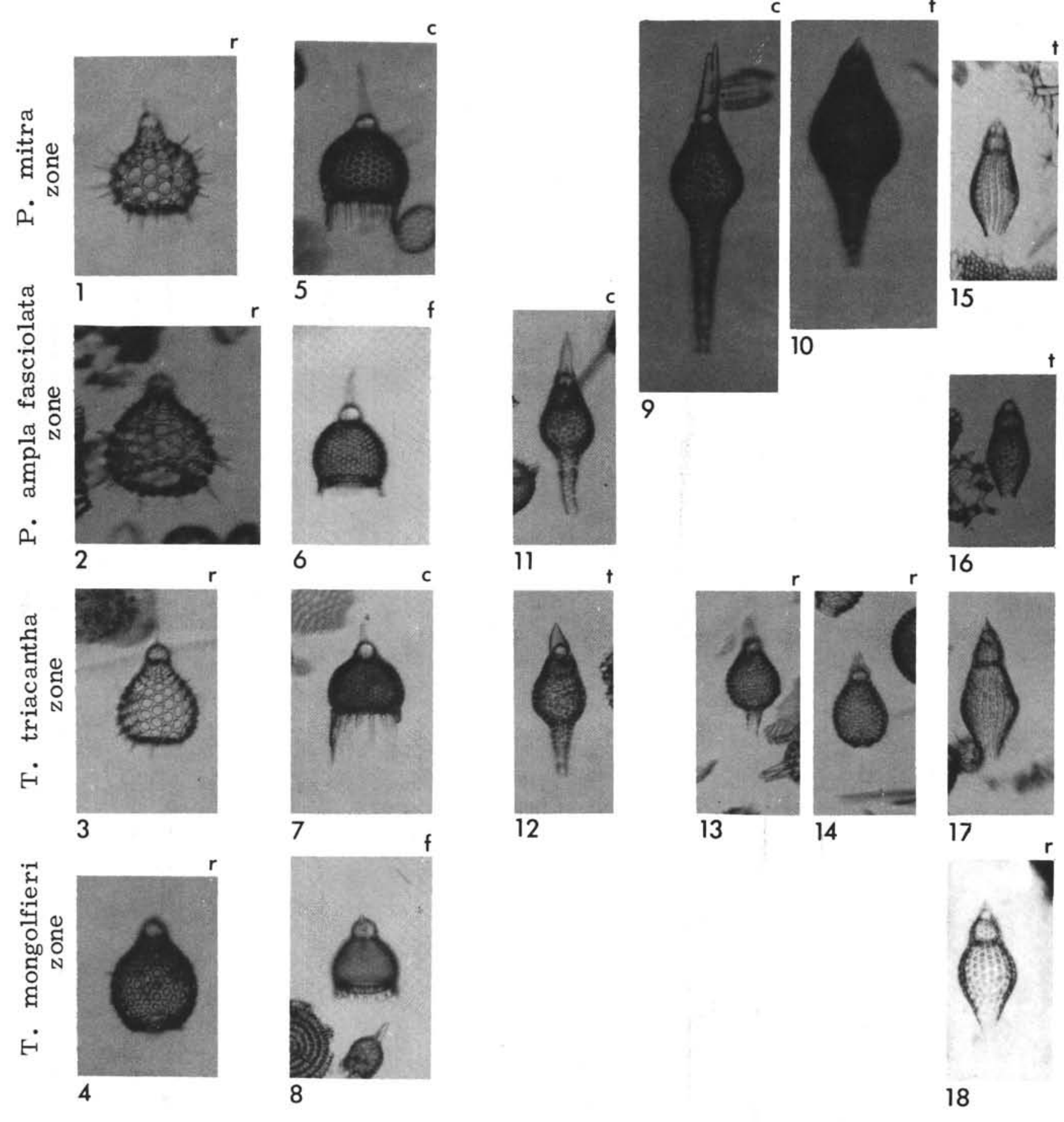




\section{PLATE 1G}

(X110)

Figure 1

Figure 2

Figure 3

Figure 4

Figure 5

Figure 6

Figure 7

Figure 8

Figure 9

Figure 10

Figure 11

Figure 12

Figure 13

Figure 14
Lamptonium fabaeforme (?) chaunothorax Riedel and Sanfilippo; 220-15-5, 51-3 cm; A-J42/3.

Lamptonium fabaeforme (?) constrictum Riedel and Sanfilippo; 220-15-6, 50-2 cm; B-N16/2.

Lamptonium fabaeforme fabaeforme (Krasheninnikov) (?); 220-16-2, 47-9 cm; B-X22/0.

Lithochytris vespertilio Ehrenberg; 219-19-5, 47-9 $\mathrm{cm} ; \mathrm{A}-\mathrm{V} 17 / 3$.

Lithochytris vespertilio Ehrenberg; 219-20-4, 47-9 $\mathrm{cm} ; \mathrm{A}-\mathrm{W} 30 / 2$.

Lithochytris vespertilio Ehrenberg; 220-12, CC; C-040/1.

Lithochytris archaea Riedel and Sanfilippo; 220-15-3, $50-2 \mathrm{~cm} ; \mathrm{A}-\mathrm{R} 46 / 4$. (approaching $L$. vespertilio)

Lithochytris archaea Riedel and Sanfilippo; 220-15-6; $50-2 \mathrm{~cm}, \mathrm{~A}-\mathrm{P} 30 / 0$.

Lychnocanoma babylonis Clark and Campbell group; 219-19-5, 47-9 cm; A-H47/0.

Lychnocanoma babylonis Clark and Campbell group; 219-18, CC; A-S38/4.

Lychnocanoma babylonis Clark and Campbell group; 219-20-4, 47-9 cm; A-U21/2.

Lychnocanoma babylonis Clark and Campbell group; 219-20-4, $47-9$ cm; A-F29/1.

Lychnocanoma babylonis Clark and Campbell group; 220-13, CC; C-E17/3.

Lychnocanoma babylonis Clark and Campbell group; 220-15, CC; A-W37/4. 


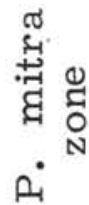

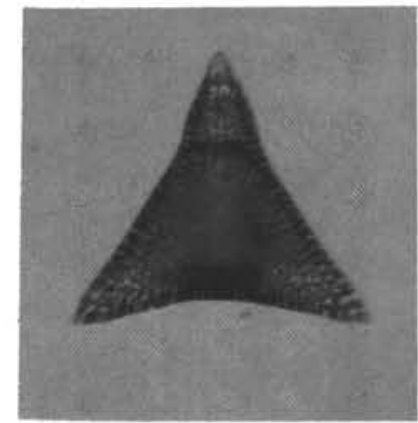

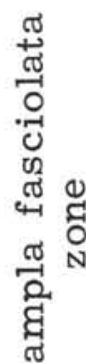

4
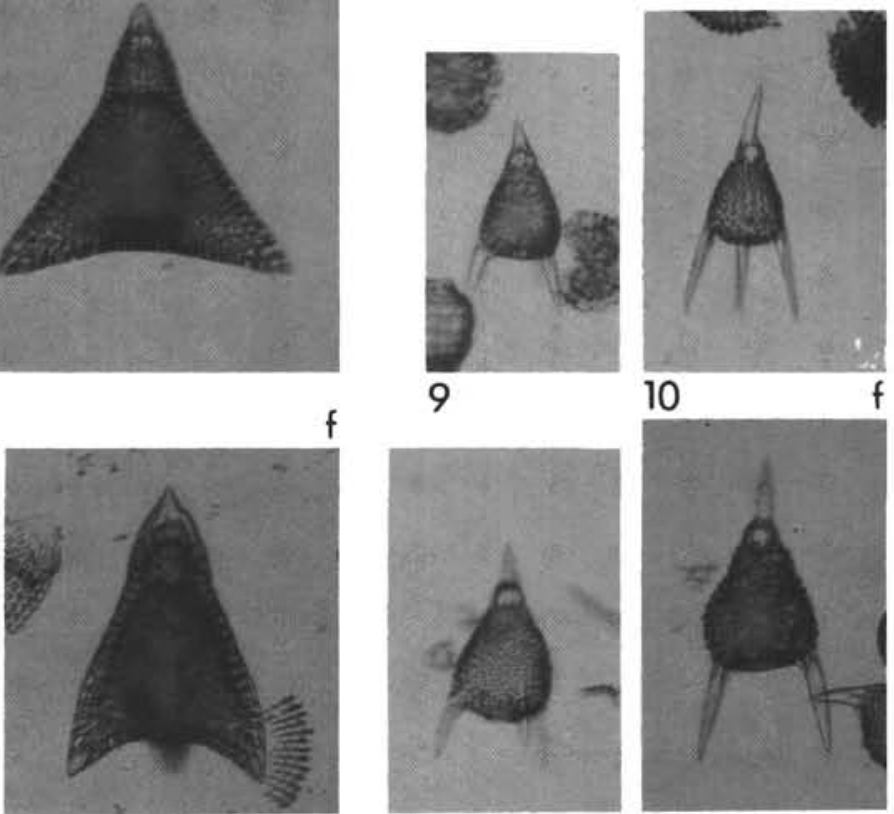

$\dot{0}_{1}$

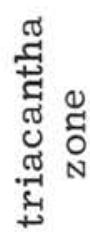

Eं

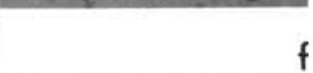

11
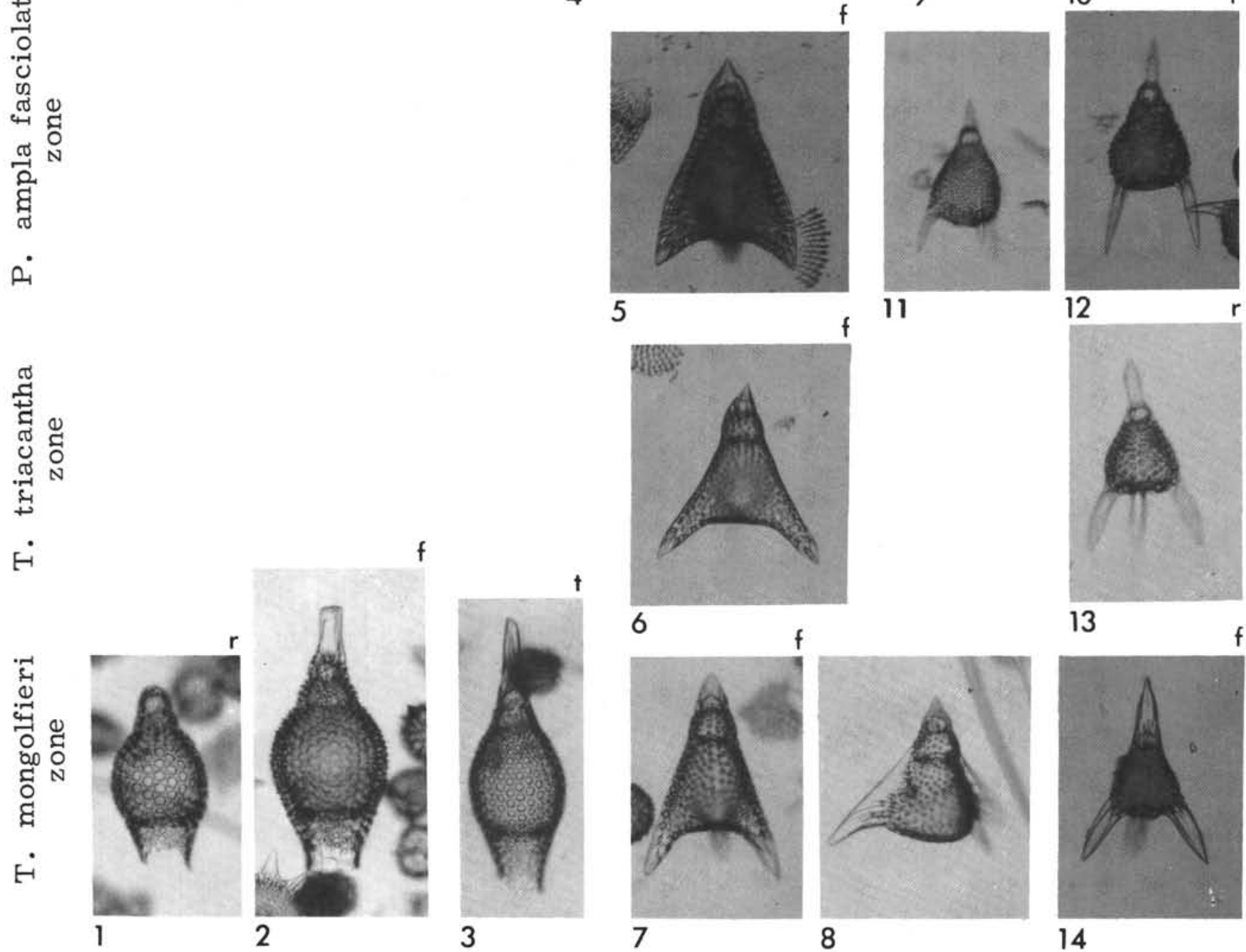

12

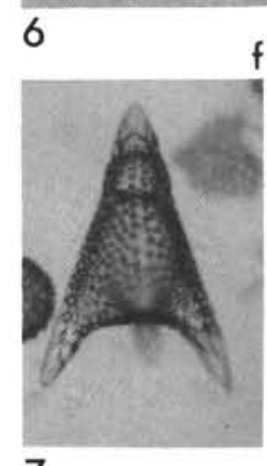

7

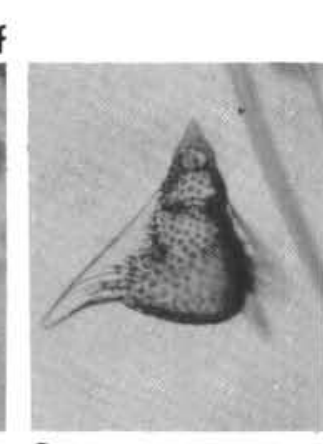

8

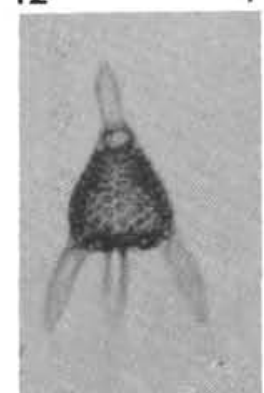

13

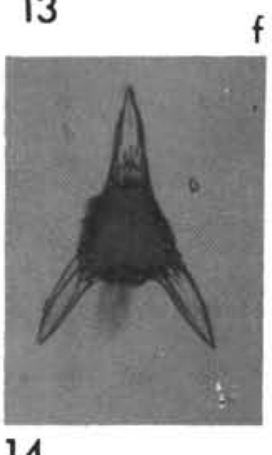

14 
PLATE $1 \mathrm{H}$

(X110)

Figure $1 \quad$ Lychnocanoma bellum (Clark and Campbell); 219-18, CC; A-G49/1.

Figure 2 Lychnocanoma bellum (Clark and Campbell); 220-14-2, 50-2 cm; B-J18/2.

Figure 3 Lychnocanoma bellum (Clark and Campbell); 220-16-2, $47-9 \mathrm{~cm}$; B-G22/4.

Figure $4 \quad$ Phormocyrtis embolum (Ehrenberg); 220-13, CC; C-Y49/0.

Figure $5 \quad$ Phormocyrtis embolum (Ehrenberg); 220-15-6, 50-2 $\mathrm{cm} ; \mathrm{A}-\mathrm{F} 55 / 3$.

Figure 6 Rhopalocanium ornatum Ehrenberg; 219-18, CC; A-W36/3.

Figure 7

Rhopalocanium ornatum Ehrenberg; 219-19-4, 46-8 $\mathrm{cm} ; \mathrm{A}-\mathrm{H} 45 / 0$.

Figure 8 Rhopalocanium ornatum Ehrenberg; 219-20-1, 125-7 $\mathrm{cm} ; \mathrm{A}-\mathrm{L} 28 / 3$.

Figure 9 Rhopalocanium ornatum Ehrenberg; 220-13-1, 50-2 $\mathrm{cm} ; \mathrm{B}-\mathrm{P} 27 / 3$.

Figure 10 Rhopalocanium ornatum Ehrenberg; 220-15-6, 50-2 $\mathrm{cm}$; B-R46/0.

Figure 11 Theocorys anapographa Riedel and Sanfilippo; 220-15-6, 50-2 cm; A-E24/0. 

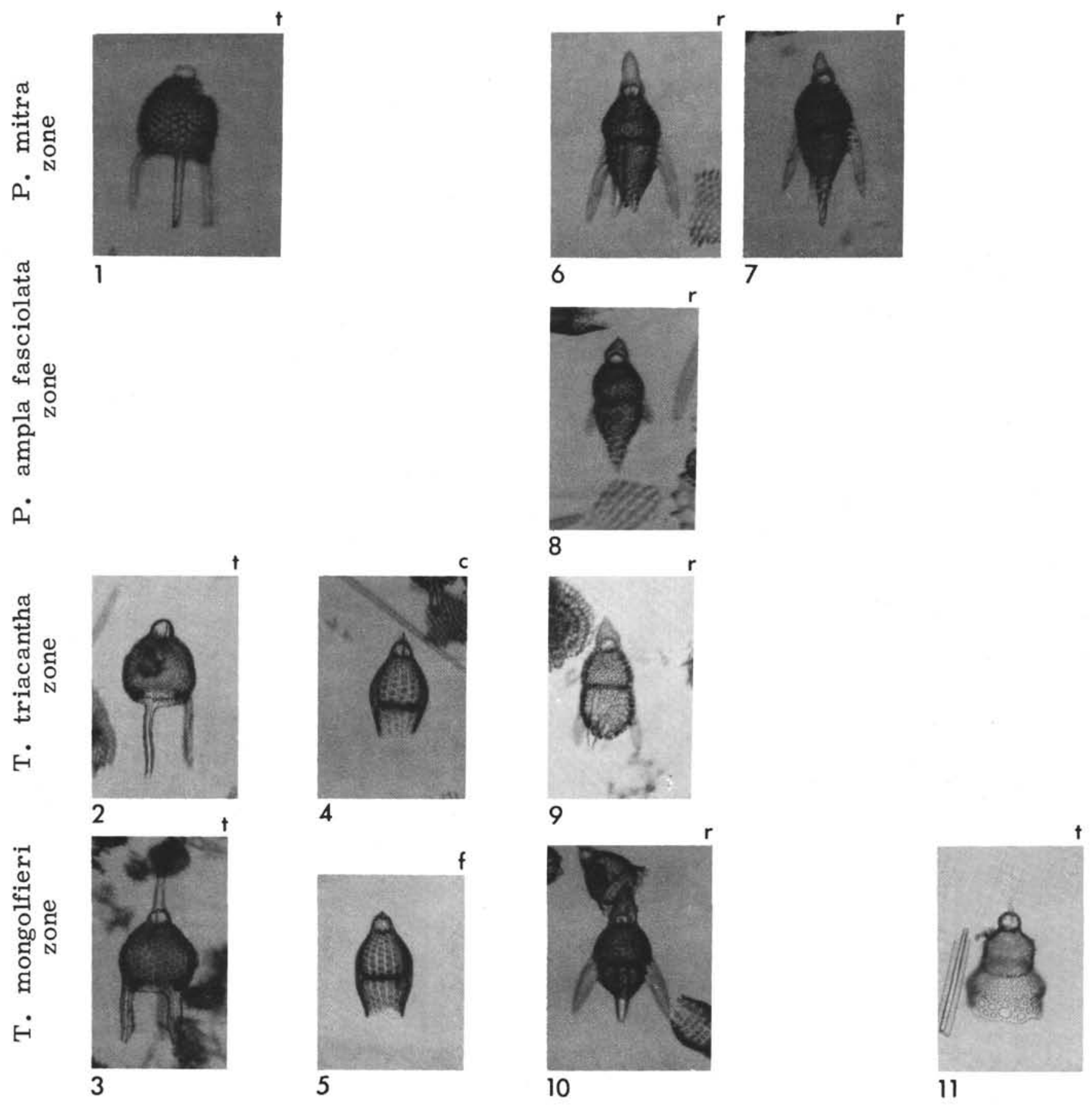


\section{PLATE 1I}

$(\times 110)$

Figure $1 \quad$ Theocotyle cryptocephala (?) nigriniae Riedel and Sanfilippo; 220-16-2, $47-9 \mathrm{~cm}$; A-T36/1.

Figure 2 Theocotyle cryptocephala cryptocephala (Ehrenberg) (?); 220-14-3, 50-2 cm; B-N23/4.

Figure 3 Theocotyle cryptocephala cryptocephala (Ehrenberg) (?); 220-15-5, 51-3 cm; A-K53/0.

Figure 4 Theocotyle cryptocephala (?) conica Foreman; 220-14-3, 50-2 cm; A-Z50/0.

Figure 5 Theocotyle ficus (Ehrenberg); 219-19-2, 47-9 cm; A-V48/0.

Figure 6 Theocotyle ficus (Ehrenberg); 219-20-4, $47-9 \mathrm{~cm}$; A-J30/3.

Figure $7 \quad$ Theocotyle ficus (Ehrenberg); 220-12, CC; D-023/4.

Figure 8 Theocotyle ficus (Ehrenberg); 220-15-6, 50-2 cm; A-X34/3.

Figure 9 Thyrsocyrtis rhizodon Ehrenberg; 219-18, CC; A-G44/0.

Figure 10 Thyrsocyrtis rhizodon Ehrenberg; 219-20-4, 47-9 cm; A-Q38/2.

Figure 11 Thyrsocyrtis rhizodon Ehrenberg; 219-20-4, 47-9 cm; A-P39/2.

Figure 12 Thyrsocyrtis rhizodon Ehrenberg; 220-13, CC; C-L22/4.

Figure 13 Thyrsocyrtis rhizodon Ehrenberg; 220-15-6, 50-2 cm; A-U30/0. 

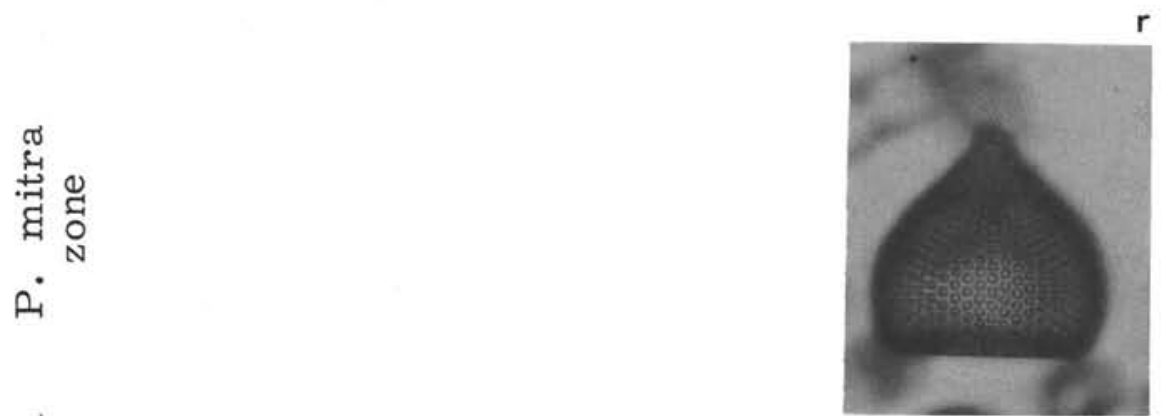

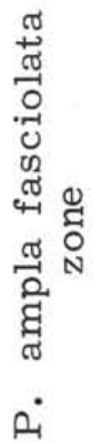
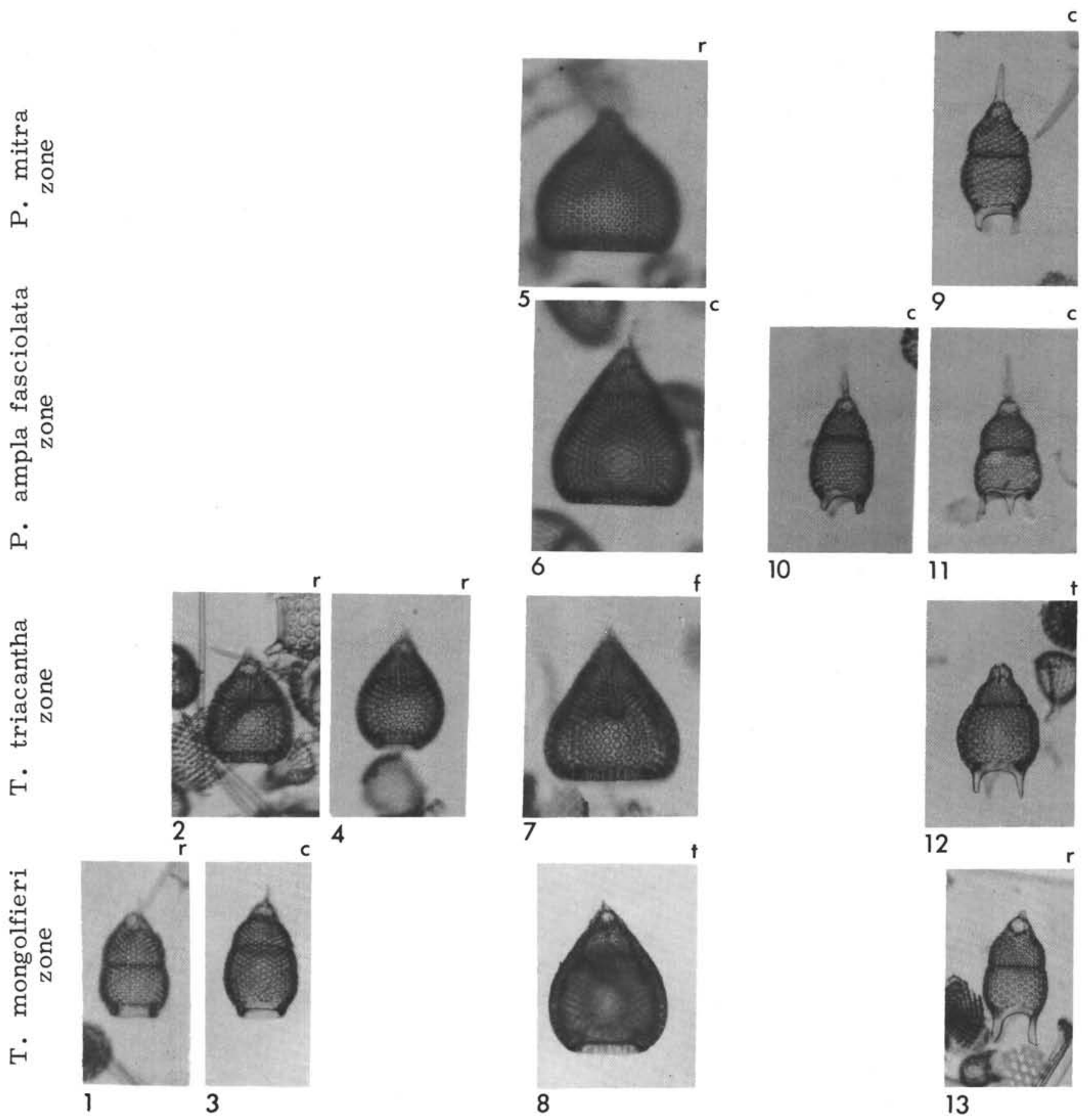


\section{PLATE 1J}

$(X 110)$

Figure 1 Thyrsocyrtis hirsuta hirsuta (Krasheninnokov); 220-15, CC; B-J50/0.

Figure 2 Thyrsocyrtis hirsuta robusta Riedel and Sanfilippo; 220-15-2, 50-2 cm; A-D55/0.

Figure 3 Thyrsocyrtis hirsuta tensa (Foreman) (approaching $T$. triacantha); 220-14-1, 50-2 cm; A-M47/1.

Figure 4 Thyrsocyrtis hirsuta tensa Foreman; 220-15-2, 50-2 $\mathrm{cm} ; \mathrm{B}-\mathrm{G} 30 / 2$.

Figure 5 Thyrsocyrtis triacantha (Ehrenberg); 219-18, CC; A-M27/0.

Figure 6 Thyrsocyrtis triacantha (Ehrenberg) 219-20-5, 47-9 cm; B-D42/0.

Figure 7

Thyrsocyrtis triacantha (Ehrenberg); 220-12-2, 50-2 cm; B-D20/4. 

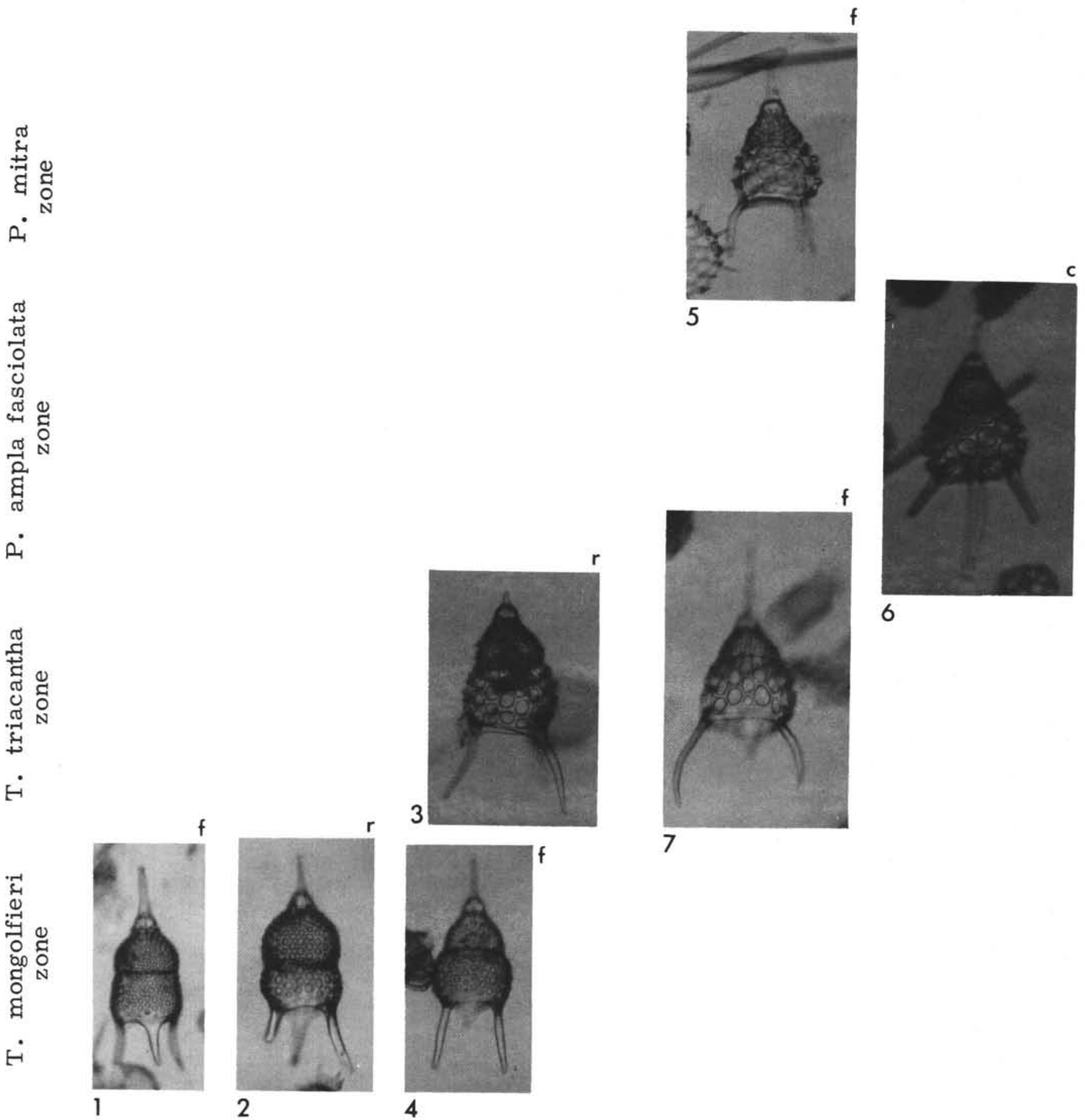


\section{PLATE 1K}

$(\times 110)$

Figure 1 Podocyrtis ampla fasciolata Nigrini, $\mathrm{n}$ subsp.; 219-20-5, 47-9 cm; A-H18/0.

Figure 2 Podocyrtis ampla fasciolata Nigrini, n. subsp.; 219-20-3, 46-8 cm; A-U30/2.

Figure 3 Podocyrtis diamesa Riedel and Sanfilippo; 220-13, CC; D-F19/2.

Figure 4 Podocyrtis diamesa Riedel and Sanfilippo; 220-15-3, 50-2 cm; B-W16/0.

Figure 5 Podocyrtis diamesa Riedel and Sanfilippo; 220-15-6, $50-2 \mathrm{~cm} ; \mathrm{A}-\mathrm{U} 37 / 0$.

Figure 6 Podocyrtis dorus Sanfilippo and Riedel; 220-12-5, 50-2 cm; A-K54/0.

Figure 7 Podocyrtis papalis Ehrenberg; 219-18, CC; A-V17/0.

Figure 8 Podocyrtis papalis Ehrenberg; 219-20-4, 47-9 cm; A-M18/0.

Figure 9 Podocyrtis papalis, Ehrenberg; 220-13, CC; D-Z15/3.

Figure 10 Podocyrtis papalis Ehrenberg; 220-15-6, 50-2 cm; A-P24/1.

Figure 11 Podocyrtis aphorma Riedel and Sanfilippo;220-15-3, 50-2 cm; A-X35/0.

Figure 12 Podocyrtis aphorma Riedel and Sanfilippo;220-15-6, 50-2 cm; B-H25/0. 


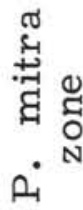
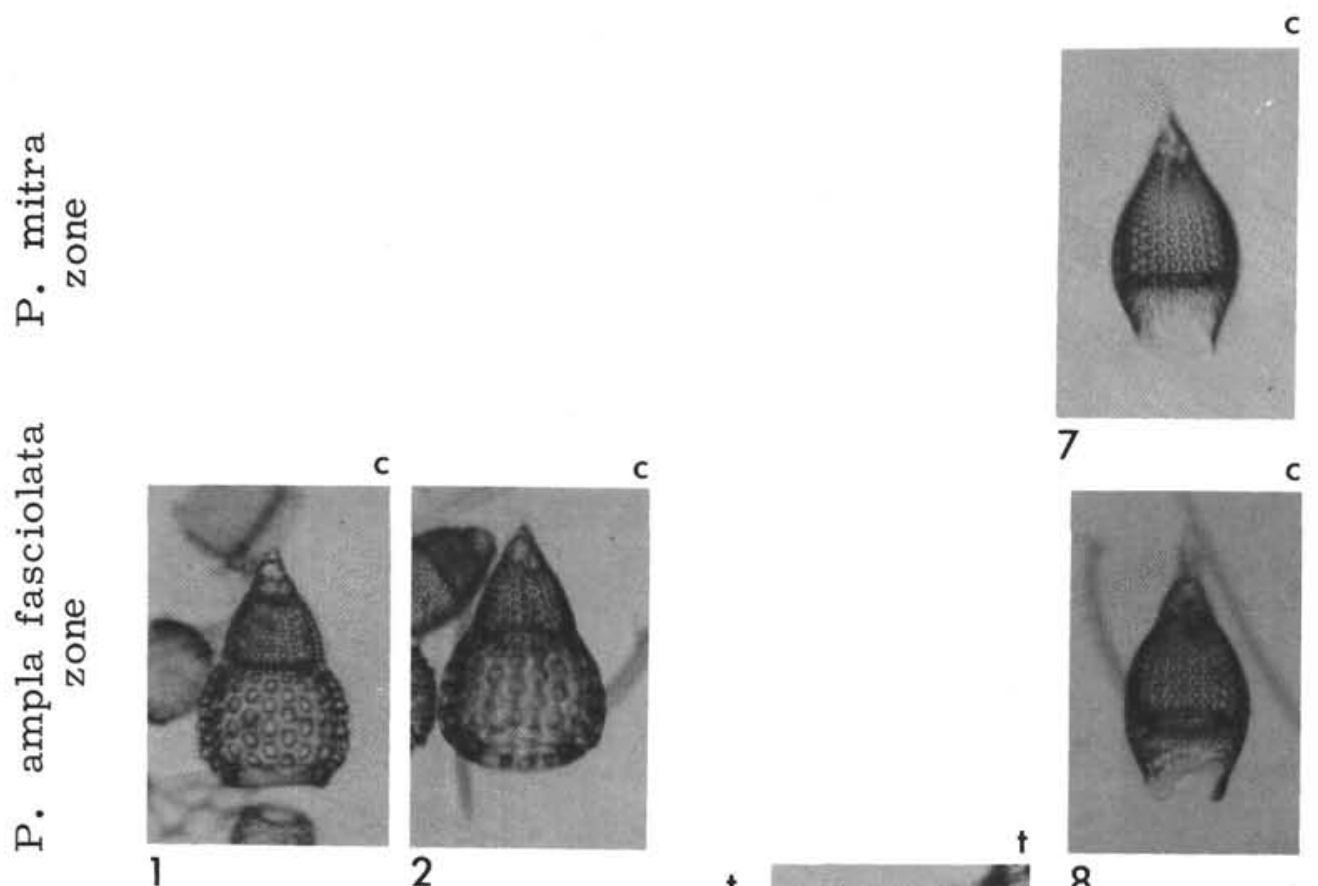

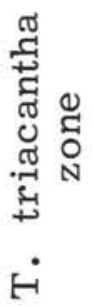
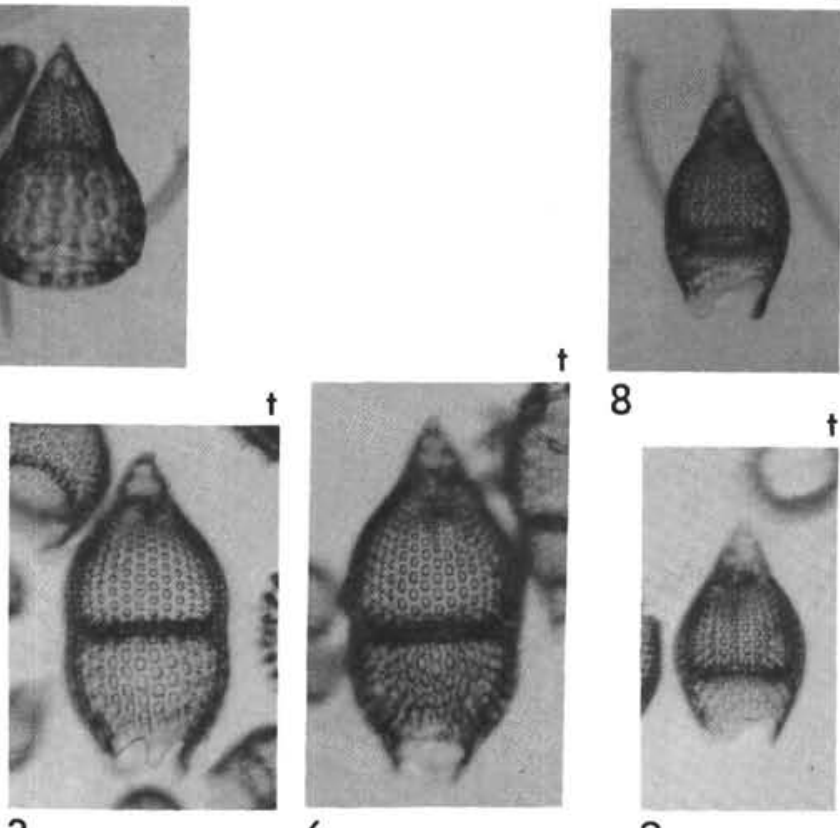

8

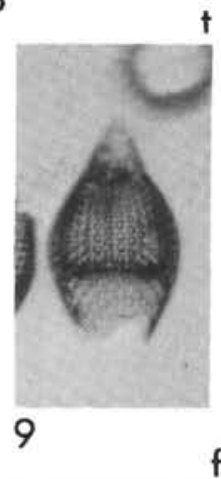

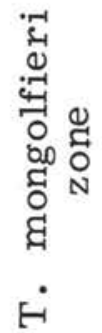
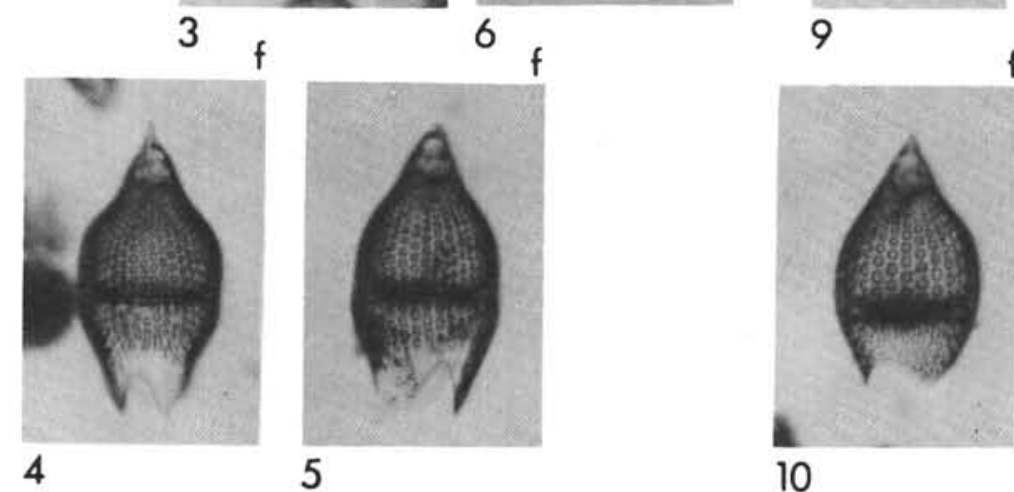

10

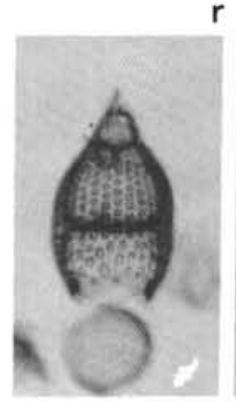

11

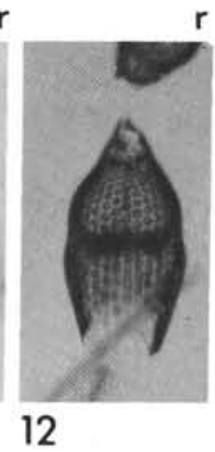




\section{PLATE 1L}

(X110)

Figure $1 \quad$ Podocyrtis sinuosa Ehrenberg (?); 219-20-3, 46-8 cm; A-M41/2.

Figure 2 Podocyrtis sinuosa Ehrenberg (?); 220-13, CC; C-M44/0.

Figure 3 Podocyrtis sinuosa Ehrenberg (?); 220-15-3, 50-2 cm; B-G55/4.

Figure 4 Podocyrtis sinuosa Ehrenberg (?); 220-15-6, 50-2 cm; B-W47/1.

Figure $5 \quad$ Podocyrtis mitra Ehrenberg; 220-18, CC; A-U31/4.

Figure $6 \quad$ Podocyrtis mitra Ehrenberg; 219-19-5, 47-9 cm; A-U29/3.

Figure 7 Podocyrtis trachodes Riedel and Sanfilippo; 219-18-5, $45-7 \mathrm{~cm} ; \mathrm{A}-\mathrm{N} 42 / 0$.

Figure 8 Podocyrtis trachodes Riedel and Sanfilippo; 219-20-1, 125-7 cm; A-U51/2.

Figure 9 Podocyrtis helenae Nigrini n. sp.; 219-20-3, 46-8 cm; A-047/0.

Figure $10 \quad$ Podocyrtis helenae Nigrini n. sp.; 219-20-4, 47-9 cm; A-U47/3.

Figure $11 \quad$ Podocyrtis helenae Nigrini n. sp.; 220-12-1, 130-2 cm; A-P $21 / 3$. 


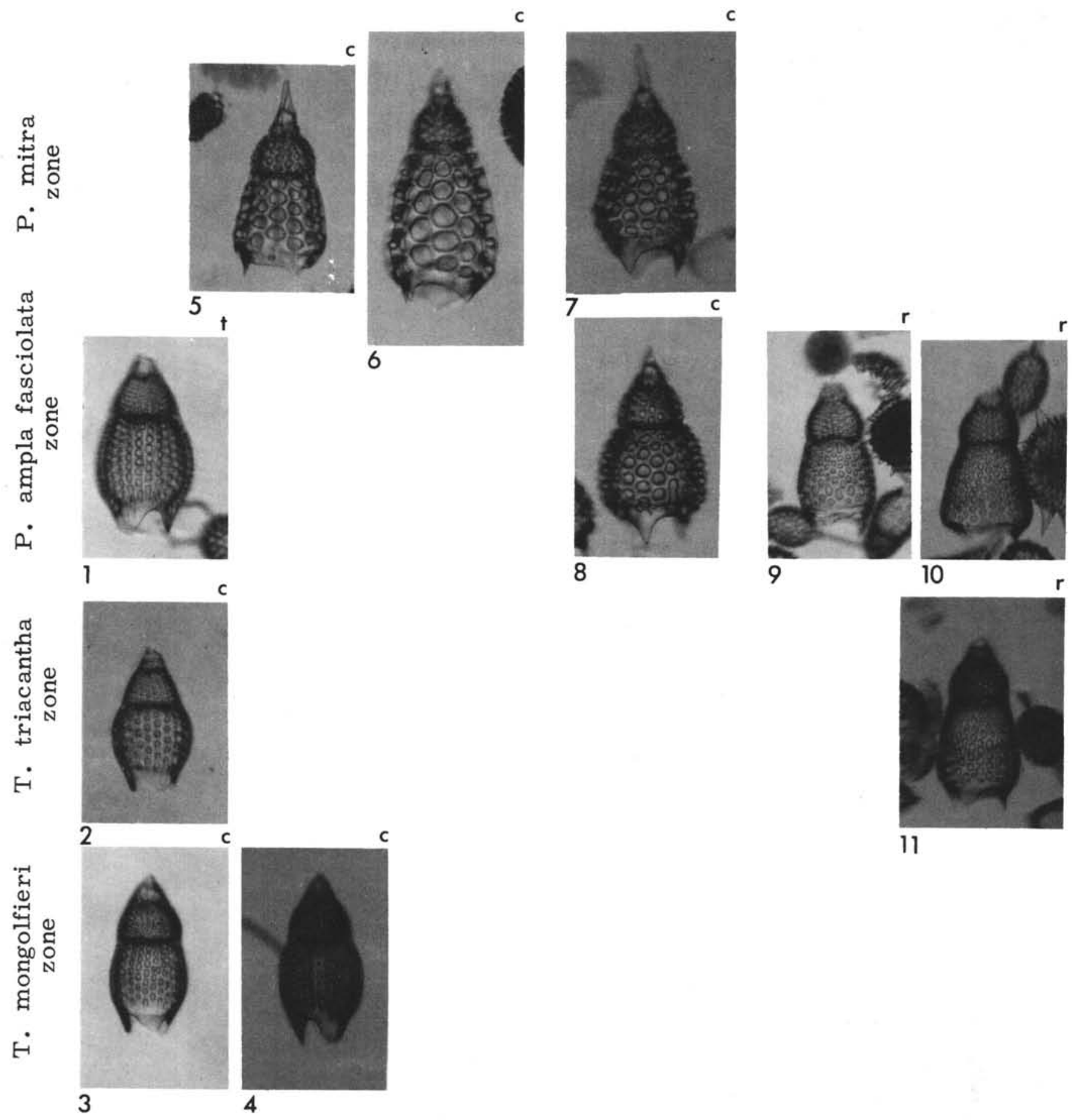




\section{PLATE $1 \mathrm{M}$}

$(\times 110)$

Figure 1 Theocampe amphora (Haeckel) group; 219-19, CC; A-S43/1.

Figure 2 Theocampe amphora (Haeckel) group; 219-20-4; A-W17/1.

Figure 3 Theocampe amphora (Haeckel) group; 220-13, CC; C-Z34/2.

Figure $4 \quad$ Theocampe amphora (Haeckel) group; 220-14, CC; A-K $33 / 4$.

Figure 5 Theocampe amphora (Haeckel) group; 220-15-3; A-P $30 / 2$.

Figure $6 \quad$ Theocampe armadillo (Haeckel) group; 219-18, CC; A-K $32 / 0$.

Figure $7 \quad$ Theocampe mongolfieri (Ehrenberg); 219-18, CC; A-O48/3.

Figure $8 \quad$ Theocampe mongolfieri (Ehrenberg); 219-20-4, 47-9 cm; A-T15/0.

Figure 9 Theocampe mongolfieri (Ehrenberg); 220-12, CC; C-R49/2.

Figure 10 Theocampe mongolfieri (Ehrenberg); 220-14, CC; A-Z27/3.

Figure $11 \quad$ Lophocyrtis biaurita (Ehrenberg); 219-20-4, 47-9 cm; A-D $43 / 1$.

Figure 12 Lophocyrtis biaurita (Ehrenberg); 220-12, CC; D-R36/0.

Figure 13 Lophocyrtis biaurita (Ehrenberg); 220-15, CC; A-W36/0.

Figure $14 \quad$ sp. cf. Lithomitra elizabethae Clark and Campbell; 219-20, CC; A-R24/0.

Figure 15 sp. cf. Lithomitra elizabethae Clark and Campbell; 220-12, CC; D-P36/3.

Figure 16 sp. cf. Lithomitra elizabethae Clark and Campbell; 220-14, CC; A-K38/0.

Figure 17 sp. cf. Lithomitra elizabethae Clark and Campbell; 220-15, CC; A-Y25/0. 

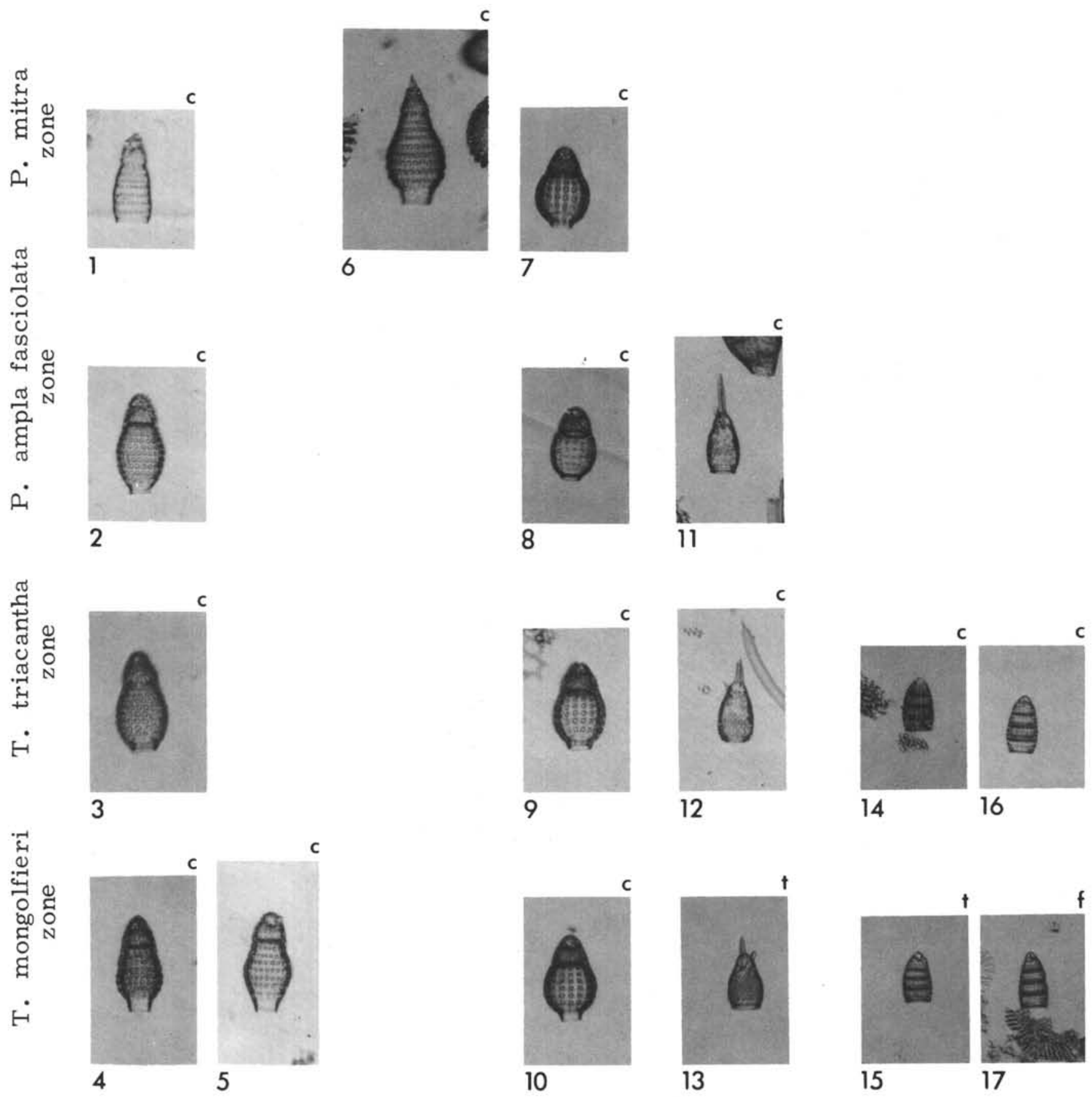


\section{PLATE 2A}

$(X 110)$

Figure 1

Figure 2

Figure 3

Figure 4

Figure 5

Figure 6

Figure 7

Figure 8

Figure 9
Cannartus prismaticus (Haeckel); 220-6-3, 50-2 cm; A-X18/2.

Cannartus prismaticus (Haeckel); 220-7, CC; A-F48/1.

Periphaena decora Ehrenberg; 219-18-2, 50-2 cm; A-G32/0.

?Lithocyclia angustum (Riedel); 220-7-2, $50-2 \mathrm{~cm}$; A-Y46/2.

Lithocyclia angustum (Riedel); 220-9-3, 49-51 cm; A-K17/4.

Lithocyclia angustum (Riedel); 220-9-1, 50-2 cm; A-H43/4.

Lithocyclia aristotelis (Ehrenberg) group; 219-17, CC; A-U46/1.

Lithocyclia aff. crux Moore; 220-9-4, 50-2 cm; A-C23/4.

Anthocyrtoma sp.; 219-18-2; B-K20/1. 


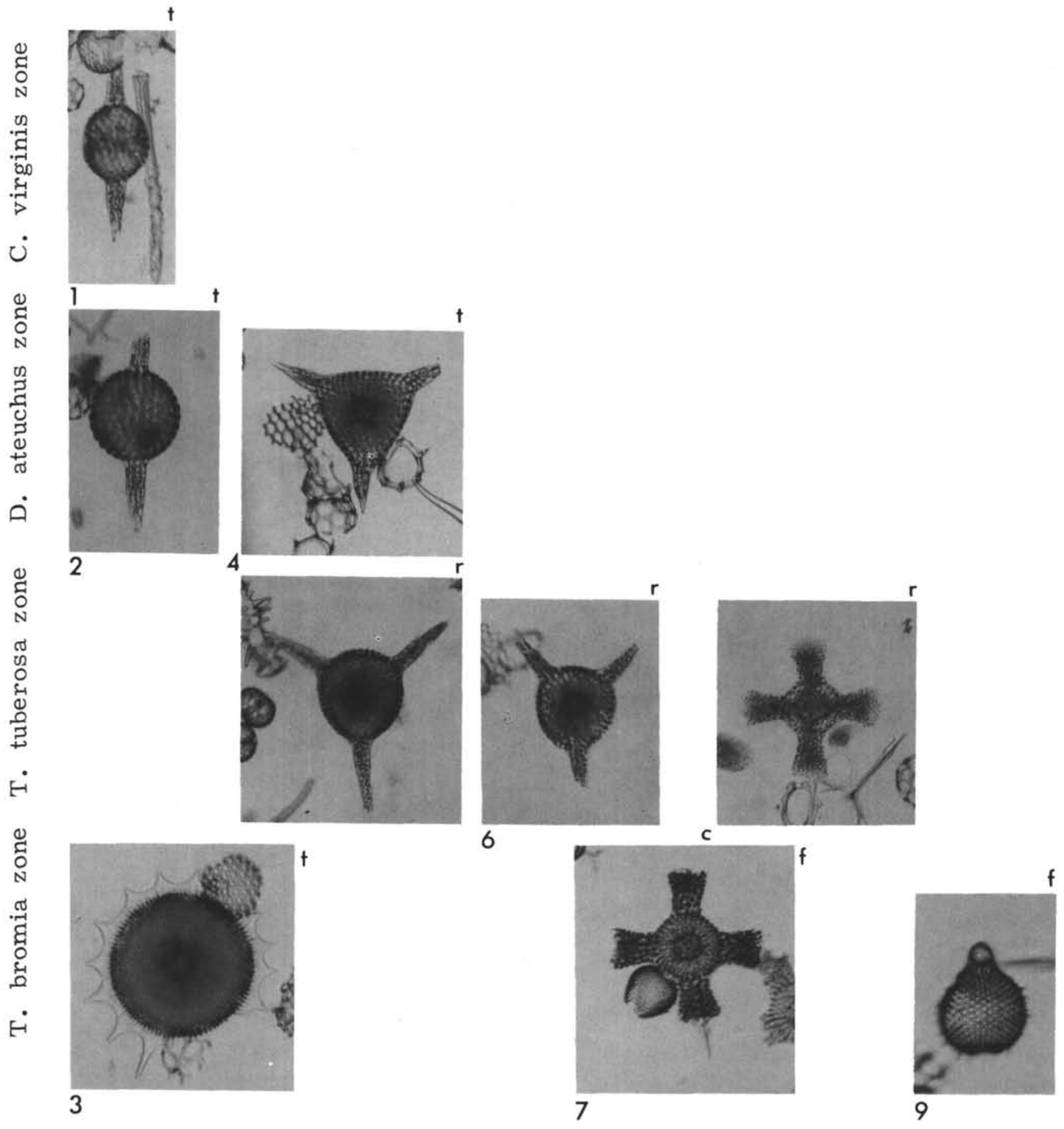




\section{PLATE 2B}

(X110)

Figure 1

Figure 2

Figure 3

Figure 4

Figure 5

Figure 6
Dorcadospyris ateuchus (Ehrenberg); 220-6, CC; A-K35/0.

Dorcadospyris ateuchus (Ehrenberg); 220-7-4, 50-2 $\mathrm{cm} ; \mathrm{A}-\mathrm{Q} 28 / 0$.

Doracdospyris circulus (Haeckel); 220-10-1, 50-2 cm; A-L31/1.

Dorcadospyris spinosa Moore; 220-10-1, 50-2 cm; A-C24/1.

Petalospyris triceros (Ehrenberg); 220-10, CC; B-T16/0.

Petalospyris triceros (Ehrenberg); 219-17-4, 47-9 cm; A-G41/2. 


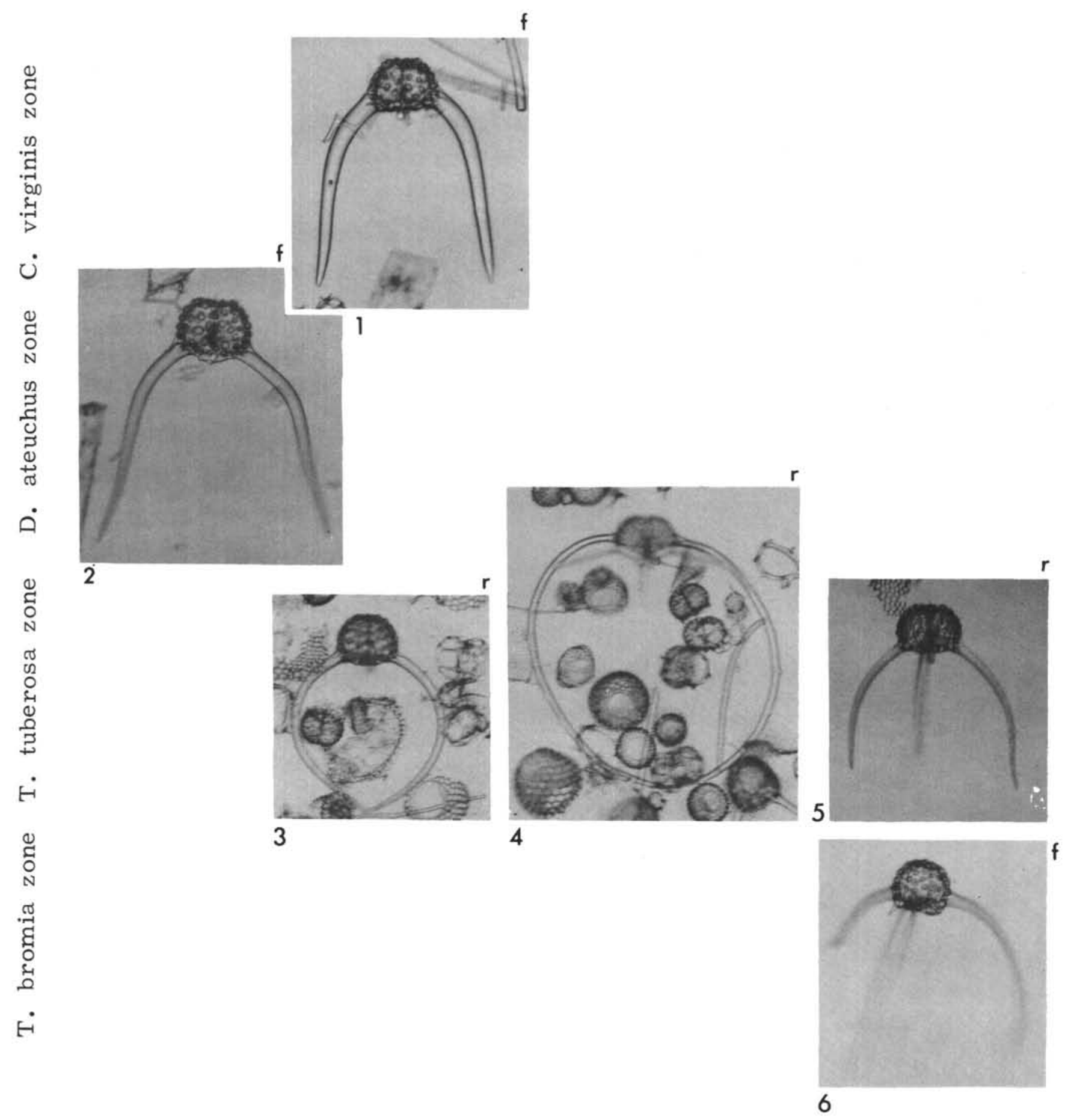




\section{PLATE 2C \\ (X110)}

Figure $1 \quad$ Artophormis gracilis Riedel; 220-6, CC; A-R42/0.

Figure 2 Artophormis gracilis Riedel; 220-6-3, 50-2 cm; A-G19/0.

Figure 3 Artophormis gracilis Riedel; 220-8-4, 50-2 cm; A-C16/3.

Figure 4 Artophormis gracilis Riedel; 220-10-1, $50-2 \mathrm{~cm}$; A-K40/1.

Figure 5 Artophormis gracilis Riedel; 220-9-3, 49-51 cm; A-G48/0.

Figure 6 Calocyclas turris Ehrenberg; 219-18-2, 50-2 cm; A-S32/3.

Figure 7 Cyclampterium pegetrum Sanfilippo and Riedel; 220-8-5, 50-2 cm; A-R40/0.

Figure 8 Cyclampterium pegetrum Sanfilippo and Riedel; 220-9-1, 50-2 cm; A-S24/0.

Figure 9 Eusyringium fistuligerum (Ehrenberg); 219-18-2, 50-2 cm; B-K $47 / 0$.

Figure 10 Lophocyrtis (?) jacchia (Ehrenberg); 219-18-2, 50-2 cm; A-O21/3. 

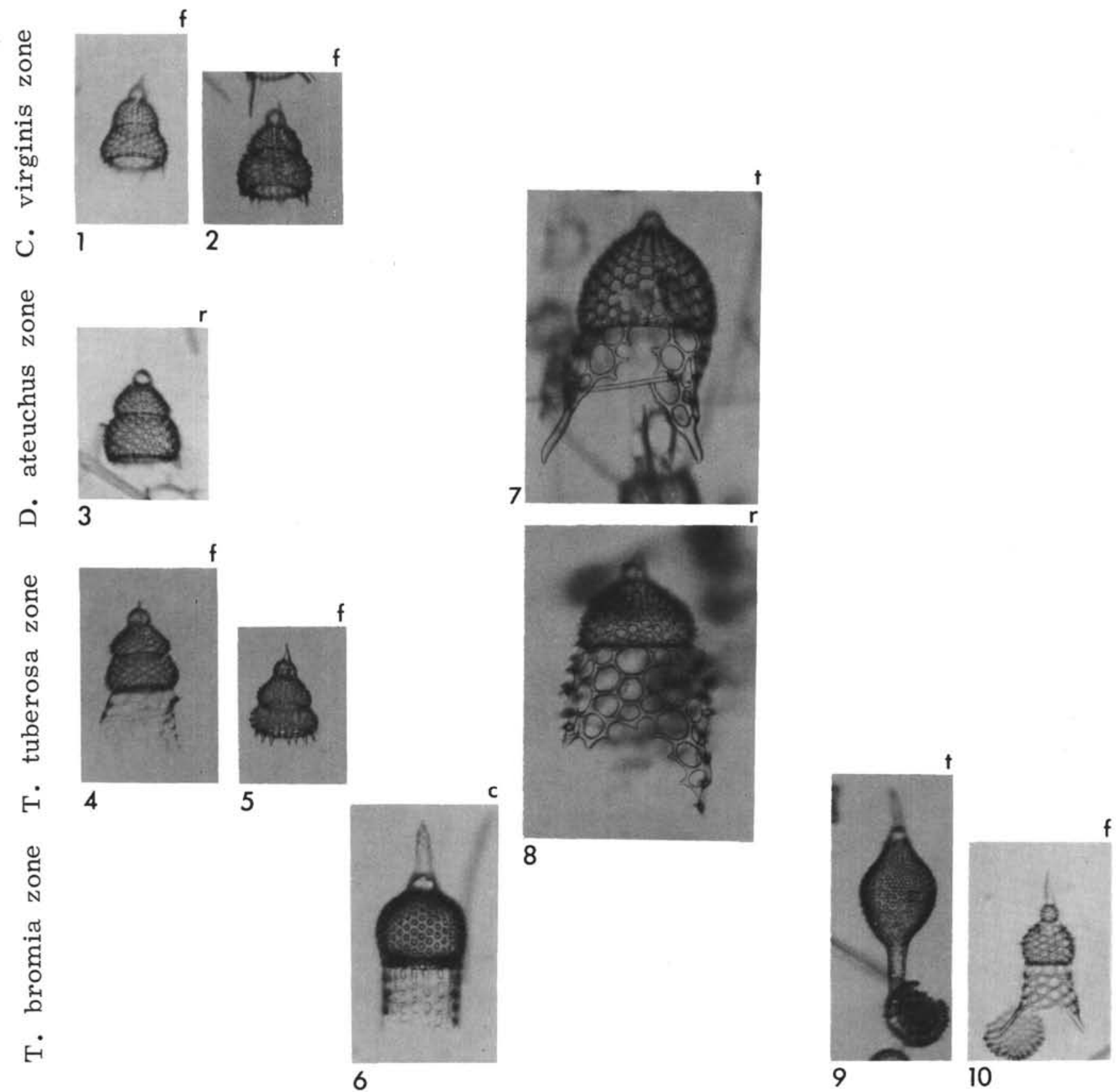


\section{PLATE 2D}

$(\times 110)$

Figure $1 \quad$ Lychnocanoma bellum (Clark and Campbell); 219-17, CC; A-N29/2.

Figure 2 Lychnocanoma amphitrite Foreman; 219-17-2, 47-9 $\mathrm{cm} ; \mathrm{A}-\mathrm{C} 13 / 1$.

Figure 3 Lychnocanoma amphitrite Foreman; 219-17-4, 47-9 $\mathrm{cm} ; \mathrm{A}-\mathrm{F} 45 / 0$.

Figure 4 Lychnocanoma babylonis (Clark and Campbell) group; 219-18-2, 50-2 cm; A-K23/2.

Figure 5 Theocorys (?) spongoconum Kling; 220-9-3, 49-51 $\mathrm{cm} ; \mathrm{A}-\mathrm{J} 32 / 4$.

Figure 6 Thyrsocyrtis bromia Ehrenberg; 219-18-2, 50-2 cm; B-U38/3.

Figure 7 Thyrsocyrtis rhizodon Ehrenberg; 219-18-2, 50-2 cm; A-M39/3. 
岂

先

ن

さ્さ

壱

$\dot{a}$

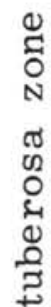

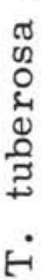

ํํำ
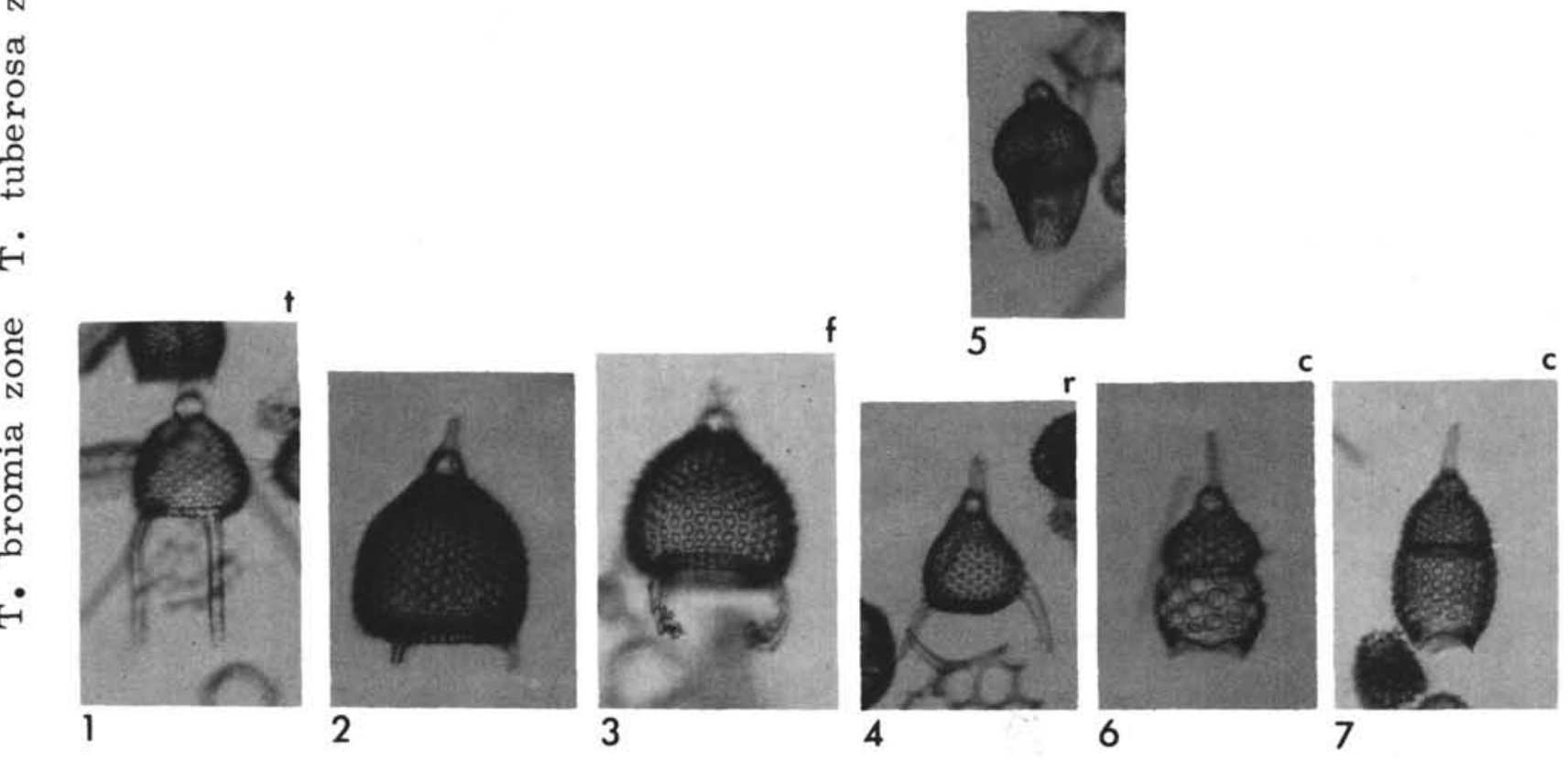


\section{PLATE 2E}

(X110)

Figure 1 Thyrsocyrtis triacantha (Ehrenberg); 219-18-2, 50-2 cm; B-U46/0.

Figure 2 Thyrsocyrtis tetracantha (Ehrenberg); 219-17, CC; A-T40/1.

Figure 3 Calocycletta virginis (Haeckel) sens. lat.; 220-6-5, 51-3 cm; B-M $44 / 4$.

Figure 4 Calocycletta virginis (Haeckel) sens. lat.; 220-6-3, 50-2 cm; A-E16/3.

Figure 5 Theocyrtis aff. tuberosa Riedel; 220-10-1, 50-2 cm; A-V43/3.

Figure 6 Theocyrtis tuberosa Riedel; 220-10-1, 50-2 cm; A-X28/2.

Figure $7 \quad$ Theocampe amphora (Haeckel) group; 219-17, CC; A-G20/3.

Figure 8 Theocampe armadillo (Ehrenberg) group; 219-18-2, 50-2 cm; B-S31/0.

Figure 9 Theocampe mongolfieri (Ehrenberg); 219-18-2, 50-2 cm; A-G36/3.

Figure $10 \quad$ Theocampe pirum (Ehrenberg); 220-10-2, 50-2 cm; A-V19/1. 


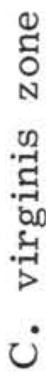

ปั

疍

$\dot{a}$

్ㅗㅇ

$\pi$
0
0
6
0
0
?
+

सं

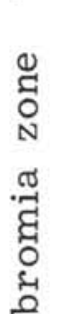

Hi

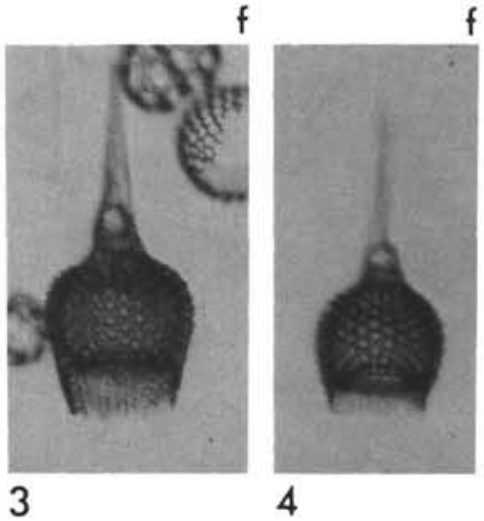

3

\section{4}
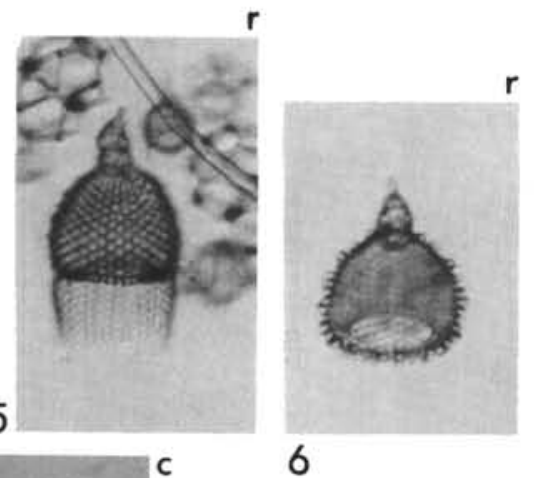

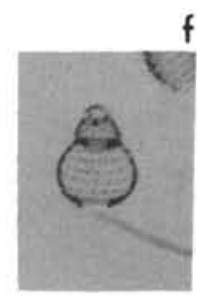

10

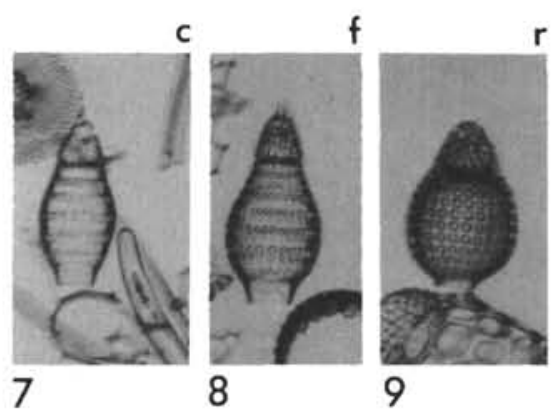




\section{PLATE 3}

( $\times 285$ except where noted)

Figure 1

Figure 2

Figure 3

Figure 4

Figure 5
Lithocyclia ocellus Ehrenberg (without medullary shell); 220-17-1, 50-2 cm; A-J19/3.

Amphicraspedum murrayanum Haeckel; 220-17-1, 50-2 cm; B-R16/0.

Spongodiscus aff. cruciferus (Clark and Campbell); 220-17-1, 50-2 cm; B-C28/3 (X110).

Spongodiscus pulcher Clark and Campbell; 220-16, CC; A-Q48/1.

Stylotrochus quadribrachiatus multibrachiatus Sanfilippo and Riedel; 220-16, CC; B-H48/3. 

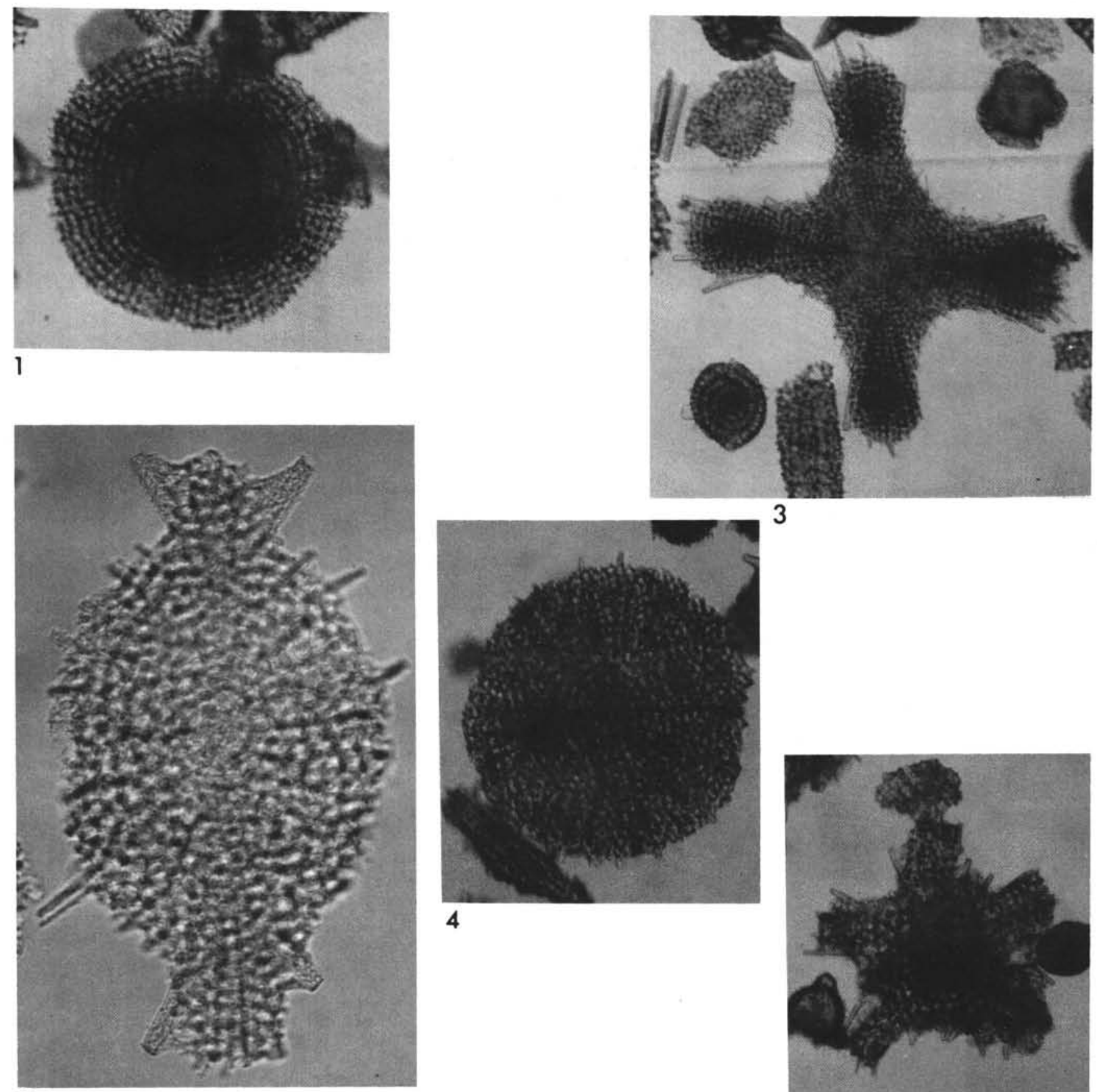

3

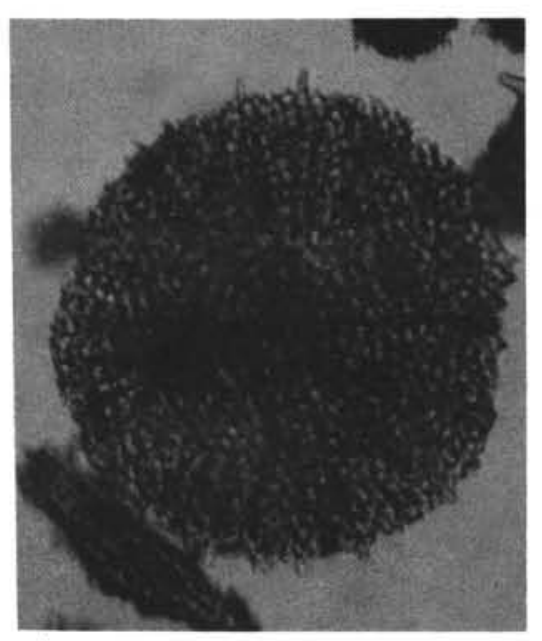

4

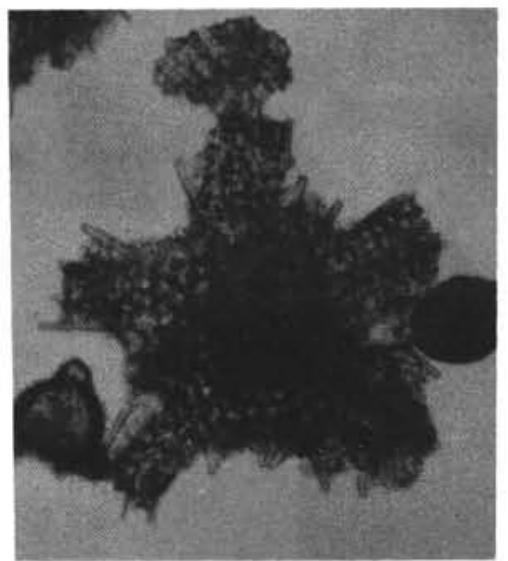




\section{PLATE 4}

$(\times 285)$

Figure 1 Buryella clinata Foreman; 220-17-1, 50-2 cm; B-D $30 / 3$.

Figure 2 Podocyrtis ampla fasciolata Nigrini, n. subsp.; HOLOTYPE; 219-20-4, 47-49 cm; A-S35/2.

Figure 3 Podocyrtis ampla fasciolata Nigrini, n. subsp.; PARATYPE; 219-20-4, 47-9 cm; A-J16/0.

Figure 4 Podocyrtis helenae Nigrini, n. sp.; HOLOTYPE; 219-20-4, 47-9 cm; A-F31/1.

Figure 4a Podocyrtis helenae Nigrini, n. sp.; HOLOTYPE; 219-20-4, 47-9 cm; A-F31/1.

Figure 5 Podocyrtis helenae Nigrini, n. sp.; PARATYPE; 219-20-4, 47-9 cm; A-M39/3.

Figure 6 sp. cf. Lithomitra elizabethae Clark and Campbell; 220-15, CC; A-X23/4.

Figure 7 sp. cf. Lithomitra elizabethae Clark and Campbell; 220-15, CC; A-Z26/3. 


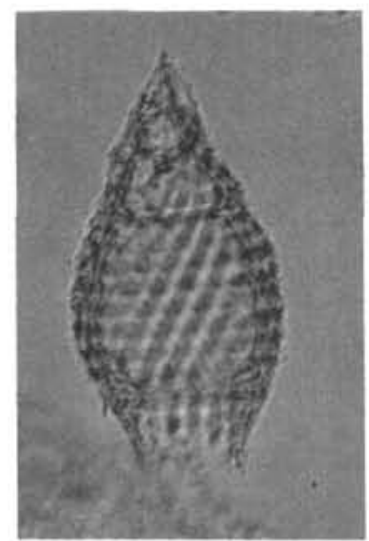

1

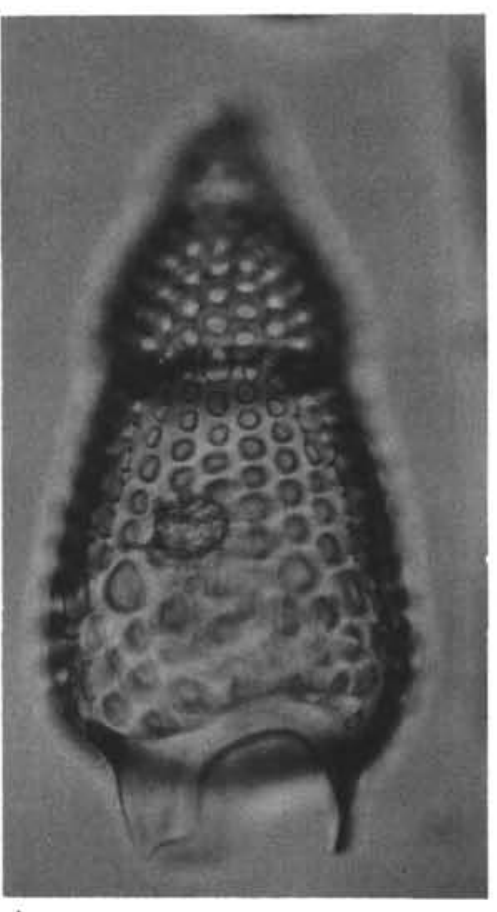

4

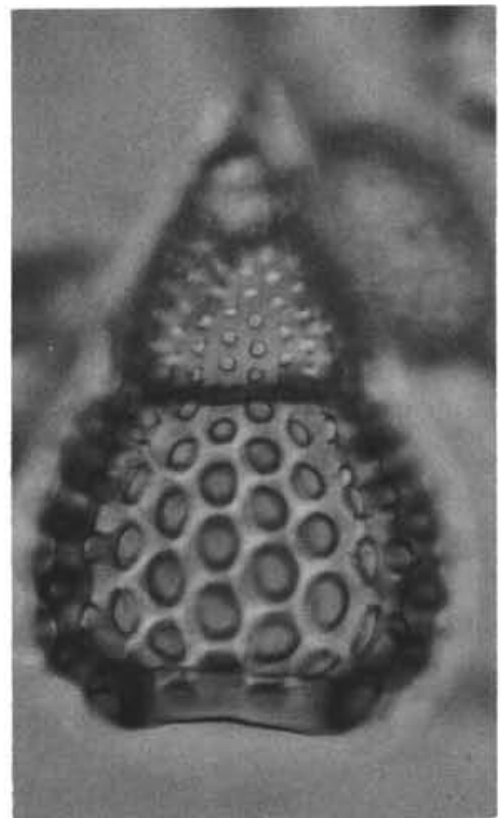

2

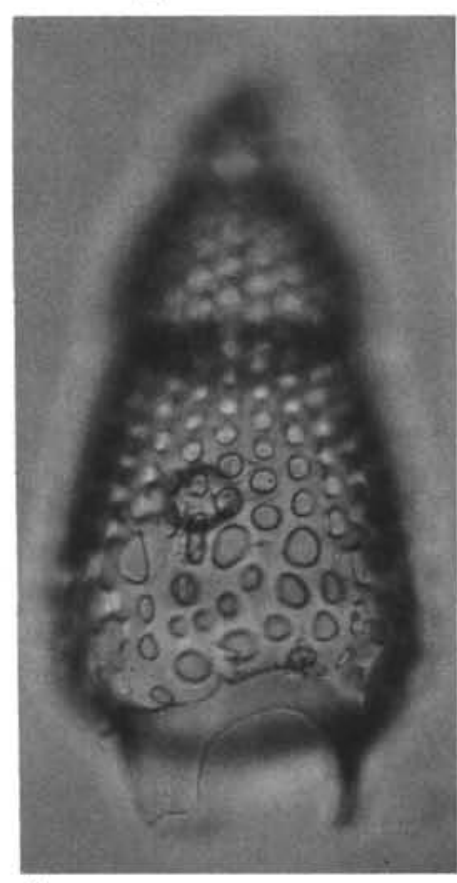

$4 a$

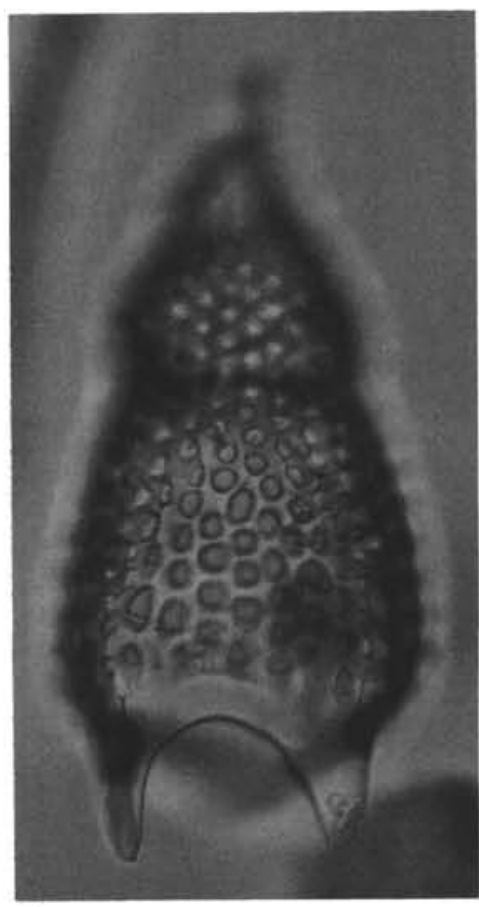

5

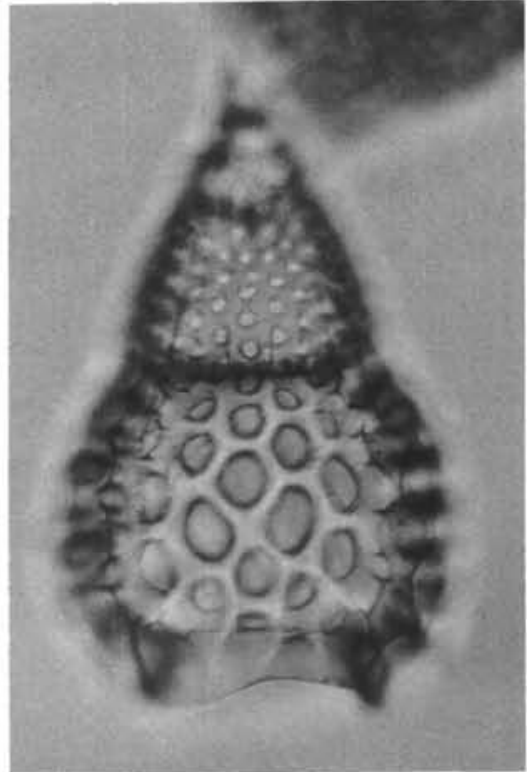

3

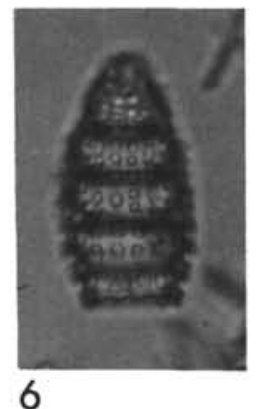

6

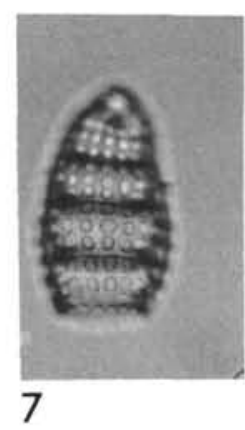




\section{PLATE 5}

Figure 1 Solenosphaera omnitubus Riedel and Sanfilippo; 223-9-2, 49-51 cm; A-M23/1.

Figure 2 Cannartus laticonus Riedel; 223-18-1, 50-2 cm; A-S44/1.

Figure 3 Cannartus (?) petterssoni Riedel and Sanfilippo; 223-19, CC; A-W40/3.

Figure $4 \quad$ Ommatartus hughesi (Campbell and Clark); 223-15, CC; B-R18/0.

Figure 5 Ommatartus antepenultimus Riedel and Sanfilippo; 223-11, CC; B-N15/0.

Figure 6 Ommatartus antepenultimus Riedel and Sanfilippo; 223-17-3, 50-2 cm; A-T46/0.

Figure $7 \quad$ Ommatartus penultimus (Riedel); 223-6-4, 54-6 cm; A-J18/1.

Figure $8 \quad$ Ommatartus penultimus (Riedel); 223-9-1, 66-8 cm; B-U34/3. 


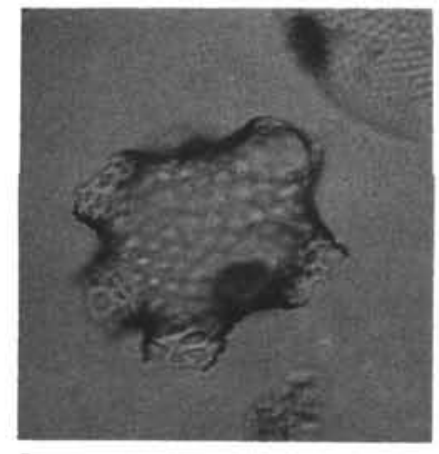

1

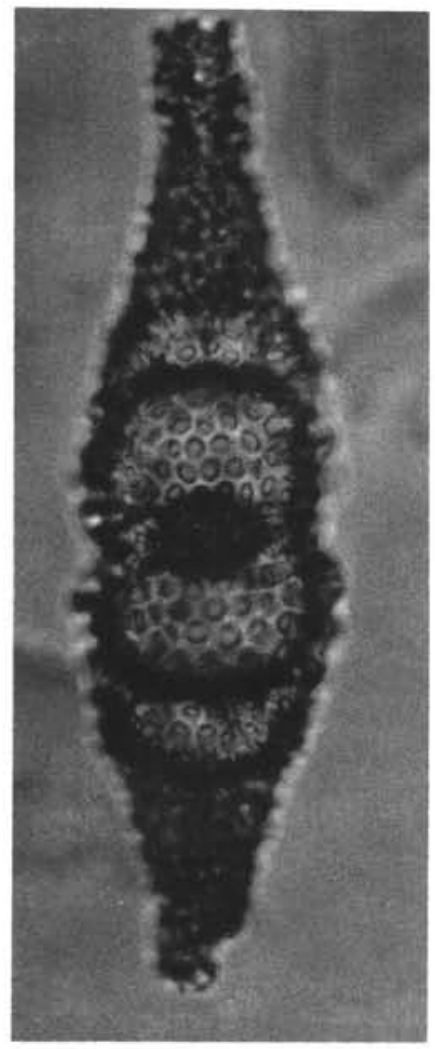

5
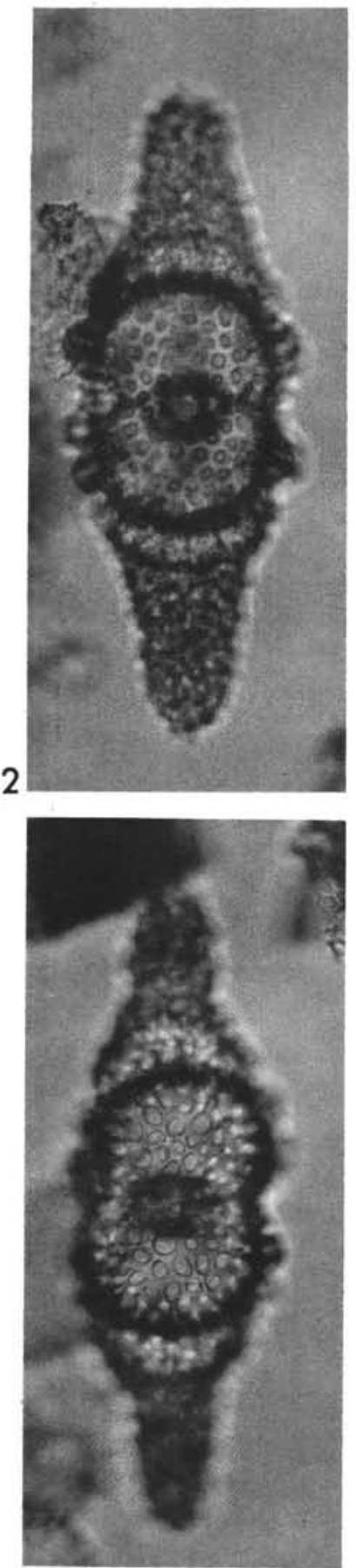

6

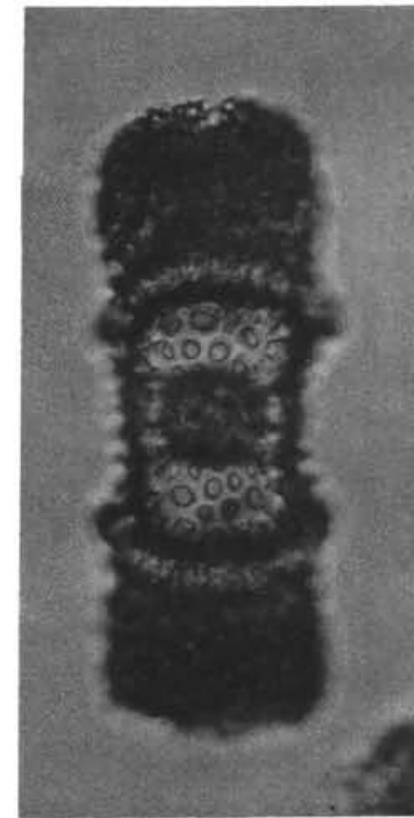

3
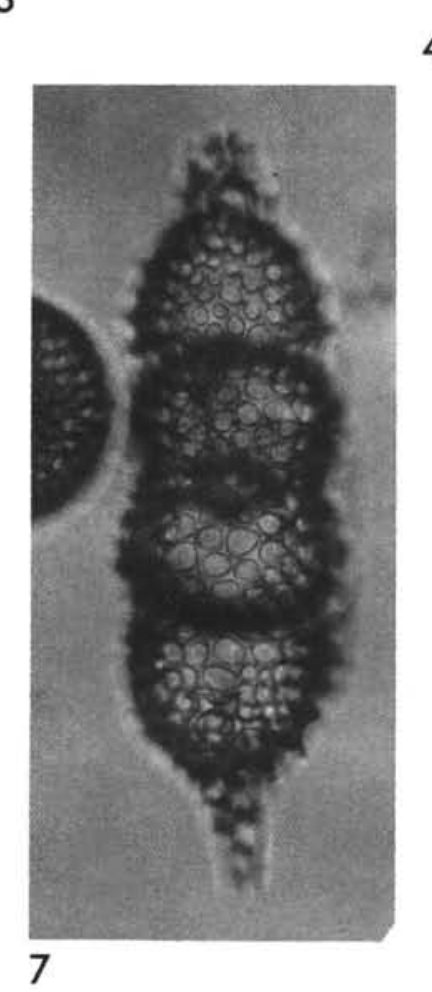
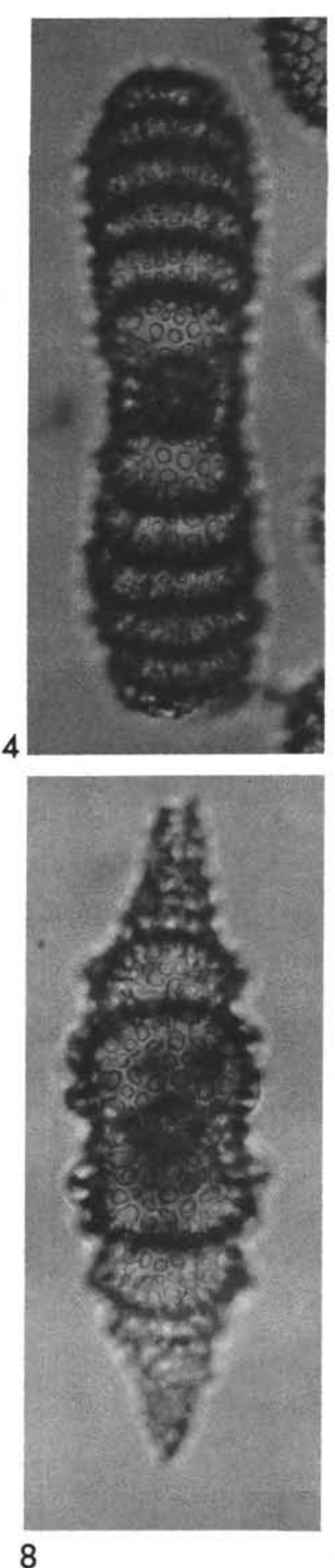


\section{PLATE 6}

(X285)

Figure 1

Figure 2

Figure 3

Figure 4

Figure 5

Ommatartus tetrathalamus (Haeckel); 223-1-1, 50-2 $\mathrm{cm} ; \mathrm{A}-\mathrm{L} 16 / 0$.

Amphirhopalum virchowii (Haeckel); 223-4-3, 50-2 $\mathrm{cm} ; \mathrm{A}-\mathrm{Q} 29 / 0$.

Amphirhopalum ypsilon Haeckel; 223-2-6, 50-2 cm; A-Y47/0.

Spongaster berminghami Campbell and Clark; 223-11-1, 110-2 cm; A-E29/0.

Spongaster aff. berminghami Campbell and Clark; 223-13, CC; B-M32/2. 


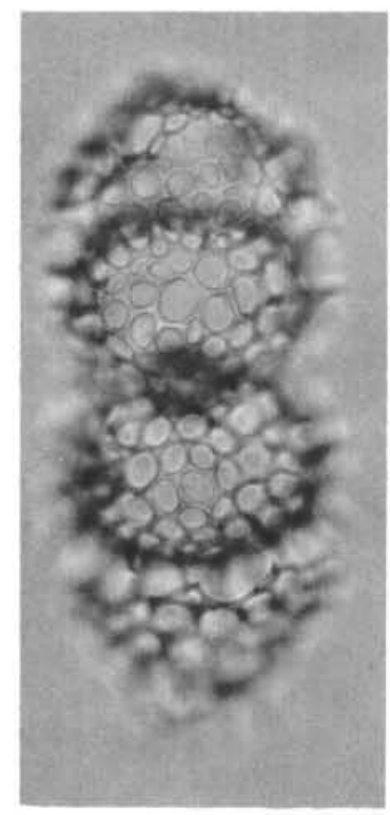

1

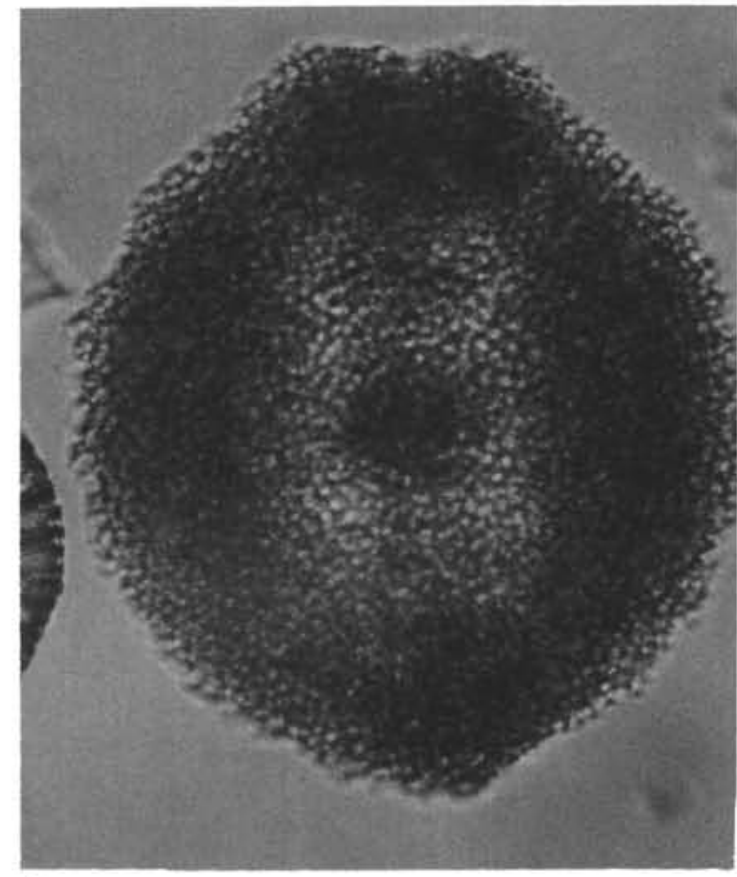

4
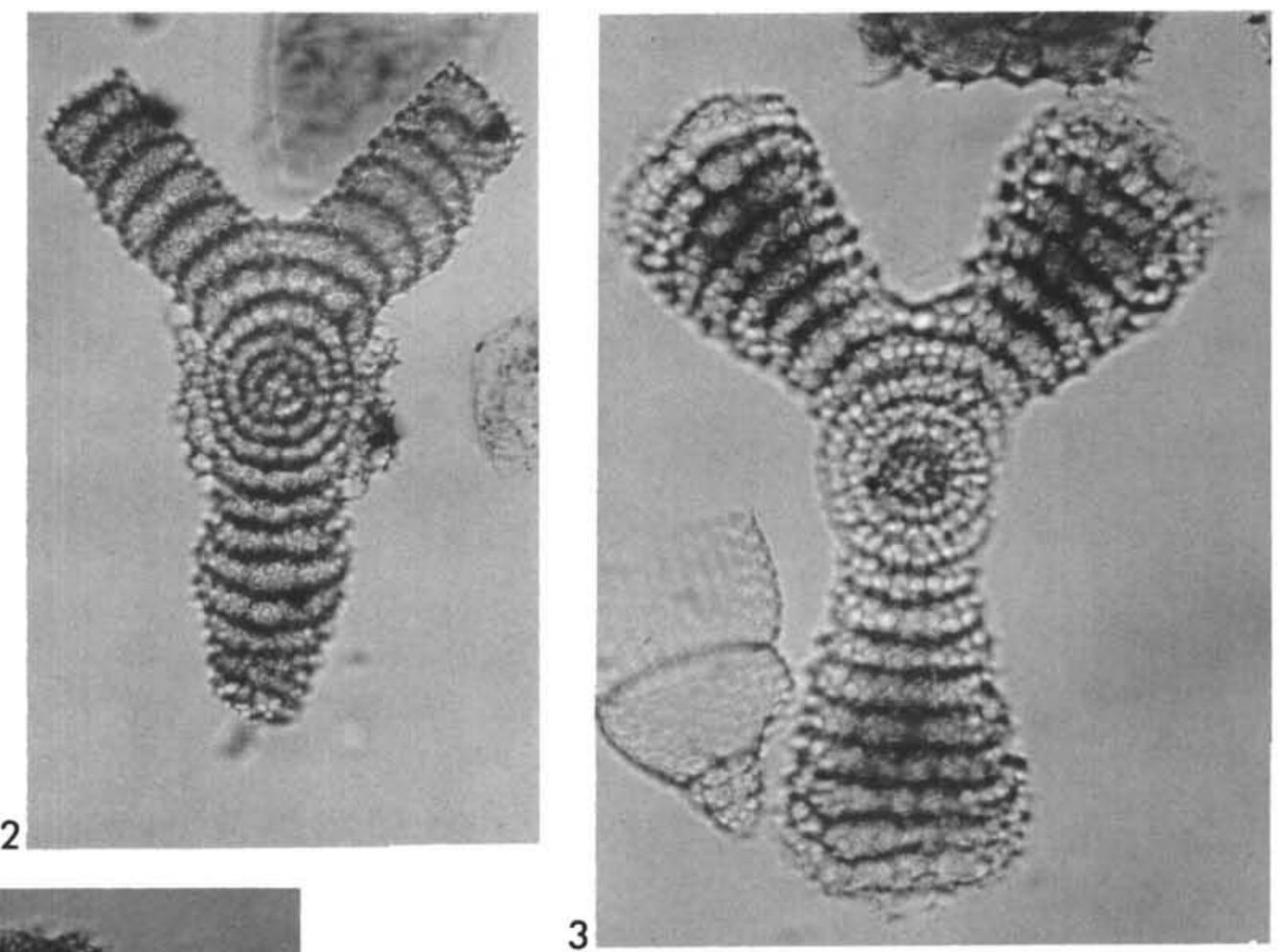

3

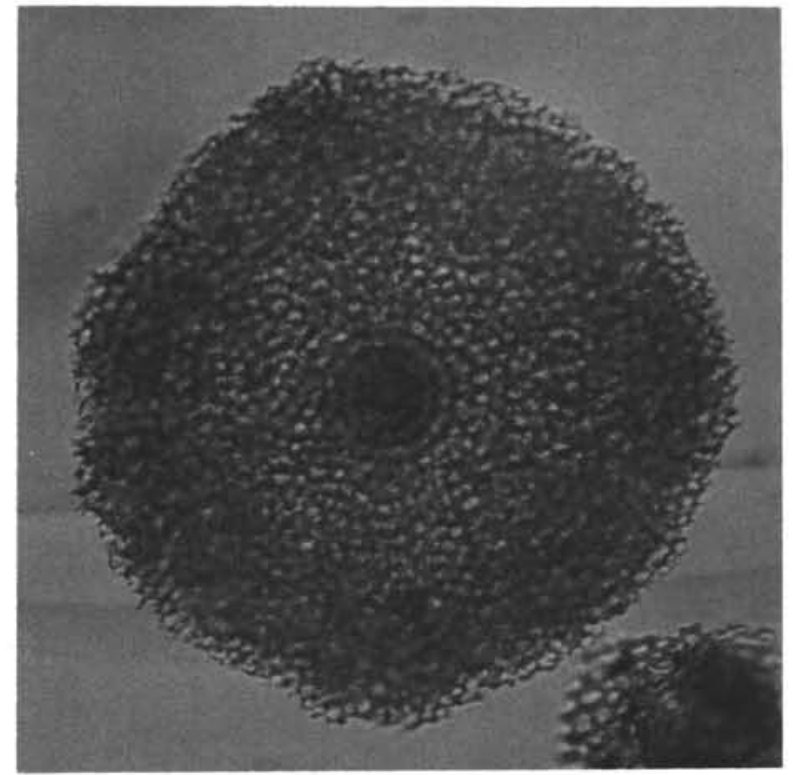

5 


\section{PLATE 7}

(X285 except where noted)

Figure $1 \quad$ Spongaster pentas Riedel and Sanfilippo; 223-6-4, 54-6 cm; A-O23/3 (X110).

Figure 2 Spongaster tetras tetras Ehrenberg; 223-2-6, 50-2 cm; A-U28/3.

Figure 3 Dictyocoryne ontongensis Riedel and Sanfilippo; 223-11-6, 50-2 cm; A-F47/0 (X110).

Figure 4 Stichocorys delmontensis (Campbell and Clark); 223-11-6, 50-2 cm; A-E37/4.

Figure 5 Stichocorys peregrina (Riedel); 223-5-4, 51-3 cm; A-Y46/0.

Figure 6 Artostrobium doliolum Riedel and Sanfilippo; 223-12-4, 52-4 cm; A-G41/2.

Figure 7 Phormostichoartus corona Haeckel; 223-12-1, 110-2 cm; A-V19/4.

Figure 8 Acrobotrys tritubus Riedel; 223-11-1, 110-2 cm; A-T37/0. 

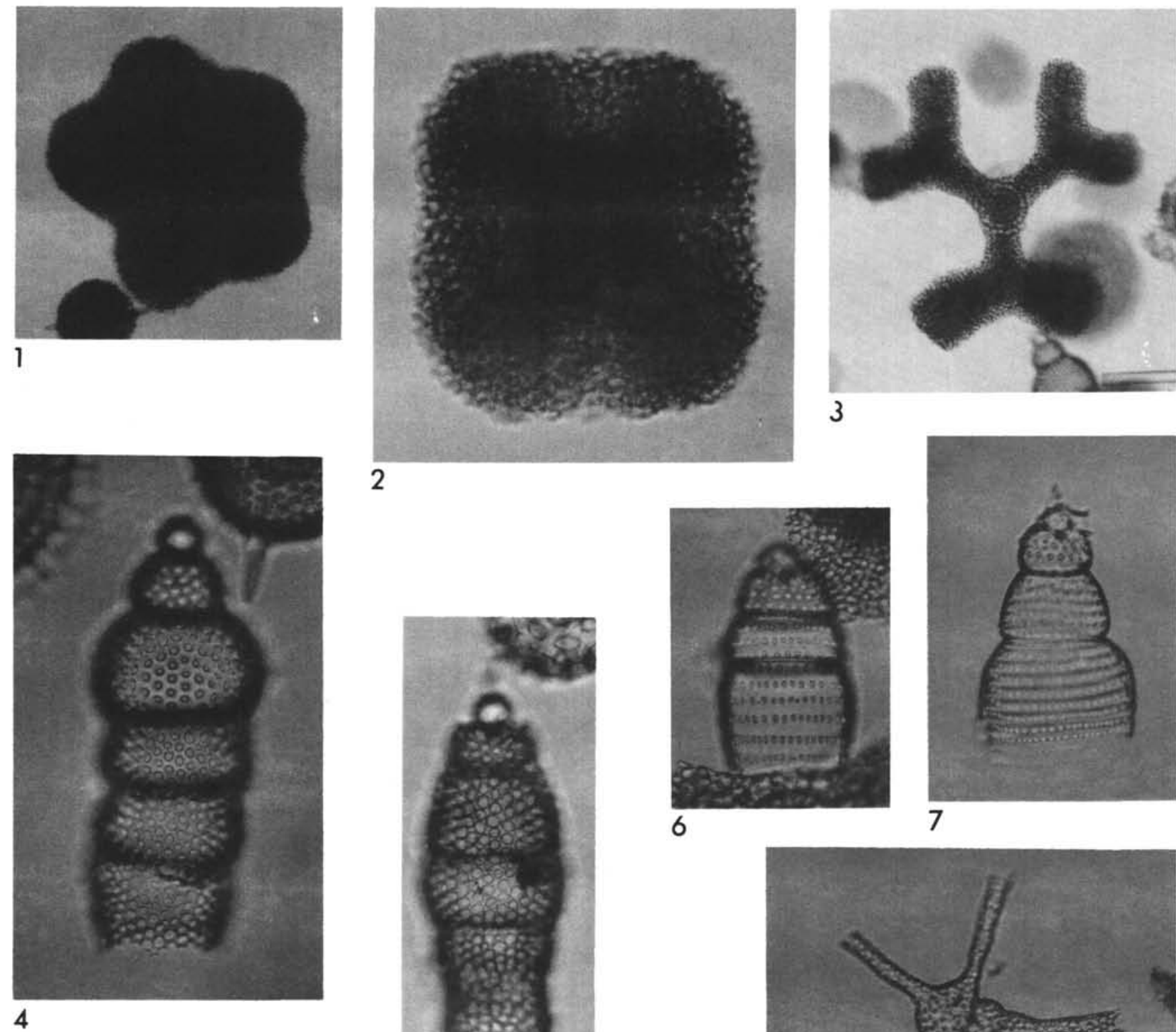

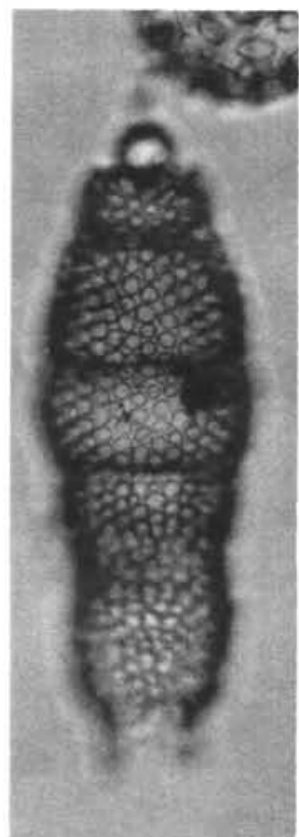

5

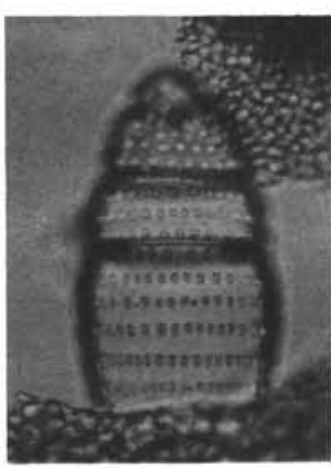

6

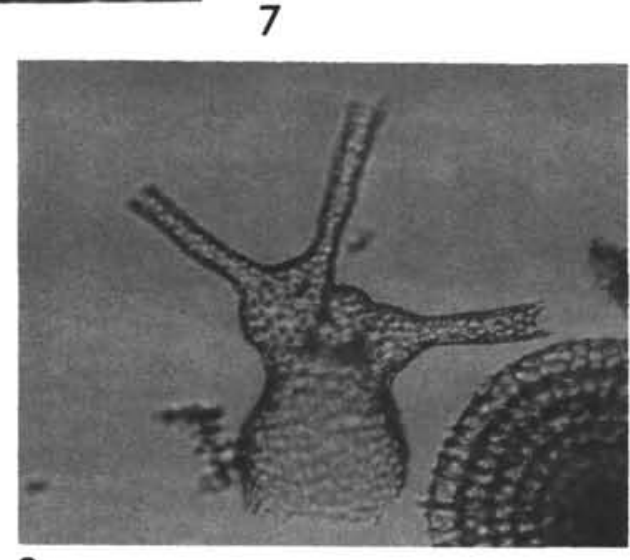

8

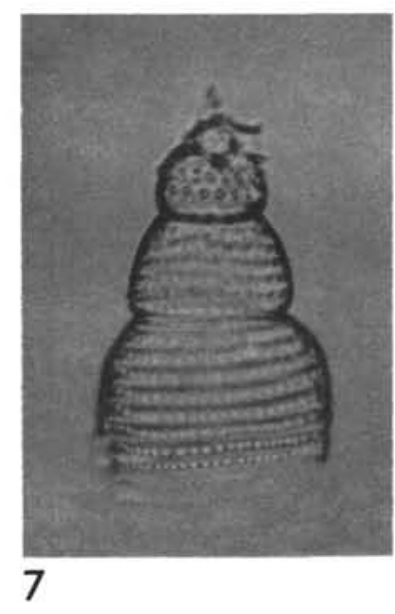




\section{INDEX TO RADIOLARIAN NAMES}

Only genus-group and species-group taxa are indexed. References are to numbered sections of the text and not to pages. The principal reference and illustrations are printed in bold face; these are preceded by entries referring to brief mentions in discussion and succeeded by tabular references to occurrences and stratigraphic range.

\section{Acrobotrys}

tritubus, 5(10)Aa; Pl. 7, fig. 8, Tab. 3, 4

Amphicraspedum murrayanum, 5(5)Aa, Pl. 3, fig. 2, Tab. 2, 5

prolixum, 5(5)Ab; PI. 1D, fig. 7, Tab. 2, 5

Amphirhopalum

virchowii, 5(5)Bb; 5(5)Ba; Pl. 6, fig. 2, Tab. 3, 4 wirchowii, 5(5)Ba, 5(5)B

ypsilon, 5(5)Bb; Pl. 6, fig. 3, Tab. 3, 4

Anthocyrtis

hispida, 5(7)Da

Anthocyrtoma

sp., 5(7)Aa, Pl. 1E, fig. 5-9; Pl. 2A, fig. 9, Tab. 1, 2

Artophormis

barbadensis, 5(7)Ba

dominasinensis, 5(7)Ba

gracilis, 5(7)Ba, PL. 2C, figs. 1-5 Tab. 2, 5

horrida, 5(7)Ba

Artostrobium

doliolum, 5(9)Aa; Pl. 7, fig. 6, Tab 3

Astractinium, 5(4)Ab

Astrocyclia

$$
\text { sp., 5(4)Ad }
$$

Astromma

aristotelis, 5(4)Ab

enthomocora, 5(2)Ab

hughesi, $5(2) \mathrm{Cb}$

petterssoni, $5(2) \mathrm{Ab}$

Buryella

clinata, 5(7)Ca, PI. 4, fig. 1, Tab. 2, 5

Calocyclas

hispida, 5(7)Da, Pl. 1F, figs 5-8, Tab. 1, 2, 5

turris, 5(7)Db, Pl. 2C, fig. 6, Tab. 1, 2, 5

virginis, 5(8)Aa

Calocycletta

veneris, $5(8) \mathrm{Aa}$

virginis, $1 ; 2 ; 3 ; 5(8) \mathrm{Ca} ; 5(8) \mathrm{Aa} ; \mathrm{PI}$. 2E, figs. 3, 4, Tab. 2,5

Calocycloma ampulla, 5(7)Ea, PI. 1F, figs. 1-4, Tab. 1, 2

Cannartus

laticonus, 5(2)Aa; PI. 5, fig. 2, Tab. 3, 4

(?)petterssoni, 1; 3; 5(2)Ab; Pl. 5, fig. 3, Tab. 3, 4

prismaticus, 5(2)Ac, Pl. 2A, figs. 1, 2, Tab. 2, 5

Cantharospyris

ateuchus, 5(6)Aa

Ceratospyris

ateuchus, 5(6)Aa

triceros, 5(6)Ba

Chitonastrum

lyra, 5(5)B

Cycladophora

hispida, 5(7)Da

turris, 5(7)Db

Cyclampterium

milowi, Tab. 5

pegetrum, 5 (7)Fa, PI. 2C, figs. 7, 8, Tab. 2,5

Cyrtocalpis

fabaeformis, 5(7) Hc

Cyrtophormis

armata, 5(7)Ba

corona, 5(9)Ba

cylindrica, 5(9)B

gracilis, 5(7)Ba

Dictyocephalus

amphora, 5(9)Ca
Dictyocoryne

ontogensis, 4; 5(5)Ca; Pl. 7, fig. 3, Tab. 3, 4

Dictyophimus

babylonis, $5(7) \mathrm{Kb}$

Dorcadospyris

ateuchus, 2; 3; 5(6)Aa, Pl. 2B, figs. 1, 2, Tab. 2, 5

circulus, 5(6)Ab; Pl. 2B, fig. 3, Tab. 2, 5

papilio, 2 ;

spinosa, 4, 5(6)Ac; P1. 2B, fig. 4, Tab. 2, 5

triceros, 5(6)Ba, Tab. 5

Euchitonia

furcata, 3

virchowii, 5(5)Ba

Eucyrtidium

ampulla, 5(7)Ea

armadillo, $5(9) \mathrm{Cb}$

biauritum, 5(11)Aa

cryptocephalum, $5(7) \mathrm{Qb}$

delmontense, 5(7) Oa

elongatum peregrinum, $5(7) \mathrm{Ob}$

embolum, 5(7)La

ficus, 5(7)Qd

fistuligerum, $5(6) \mathrm{Ga}$

mongolfieri, 5(9)Cc

pirum, $5(9) \mathrm{Cd}$

Eusyringium

conosiphon, 5(7)Lb

fistuligerum, 5(7)Lb, 5(7)Ga; P1. 1F, figs. 9-12; Pl. 2C, fig. 9, Tab. 1, 2, 5

lagena, 5(7)Gb; PI. 1F, figs. 13, 14, Tab. 1, 2, 5

striata, $5(7) \mathrm{Lb}$

tubulus, 5(7)Ga

Gamospyris

circulus, 5(6) Ab

Heliostylus sp(p)., 4; 5(3)A, pl. 1B, figs. 5-7, Tab. 1, 2, 5

Lamptonium fabaeforme (?) chaunothorax, 4 ; 5(7)Ha; PI. 1G, fig. 1, Tab. 2, 5 fabaeforme (?) constrictum, 5(7) Hb; Pl. 1G, fig. 2, Tab. 2, 5 fabaeforme fabaeforme (?), 4;5(7)Hc; PI. 1G, fig. 3, Tab. 2, 5

Lithapium

anoectum, 5(2)Ba, P1. 1A, figs. 1, 2, Tab. 1, 2 plegmacantha, 5(2)Bb, PI. 1A, figs. 3-5, Tab. 1, 2, 5

Lithocampe

sp., 5(7)Ca

Lithocampium

sp., 5(7)Ca

Lithochytris

archaea, 4; 5(7)Ia; PI. 1G, figs. 7, 8, Tab. 1, 2, 5

tripodium, 5(6) Kb

vespertilio, 4; 5(7)Ib; Pl. 1G, fig. 4-6, Tab. 1, 2, 5

Lithocyclia

angustum, 2; 5(4)Aa; Pl. 2A, figs. 4-6, Tab. 2, 5

aristotelis group, 5(4)Ab; Pl. 2A, fig. 7, Tab. 1, 2, 5

crux, 5(4)Ac

aff. crux, 5(4)Ac; PI. 2A, fig. 8, Tab. 2

ocellus group, 5(4)Aa; 5(4)Ad, PI. 1D, figs. 3-6, Tab. 1, 2, 5

Lithomitra

elizabethae, 5(11)Ba; PI. 1M, figs. 14-17; PI. 4, figs. 6, 7, Tab. 1, 2, 5

Lophocyrtis

biaurita, 5(11)Aa; PI. 1M, figs. 11-13, Tab. 1, 2, 5

(?)jacchia, 5(7)Ja, PI. 2C, fig. 10, Tab. 1, 2, 5

Lychnocanium

bellum, $5(7) \mathrm{Kc}$

bipes, 2;

sp., 5(7)Kc

Lychnocanoma

amphitrite, 4; 5(7)Ka; PI. 2D, figs. 2, 3, Tab. 1, 2, 5

babylonis group, 5(7)Kb; PI. 1G, figs. 9-14; Pl. 2D, fig. 4,

Tab. 1, 2, 5

bellum, 5(7)Kc, PI. 1H, figs. 1-3; PI. 2D, fig. 1, Tab. 1, 2, 5

elongata, 2;

trifolium, 5(7)Kd, Tab. 2 
Ommatartus

antepenultimus, $3 ; 4,5$ (2)Ca, Pl. 5, figs. 5, 6, Tab. 3, 4

hughesi, 5(2)Cb; P1. 5, fig. 4, Tab. 3, 4

penultimus, $3 ; 4 ;$ 5(2)Cc; Pl. 5, figs. 7, 8, Tab. 3, 4

tetrathalamus, 3; 5(2)Cd; PI. 6, fig. 1, Tab. 3, 4

Ommatocampe

hughesi, $5(2) \mathrm{Cb}$

Panarium

antepenultimum, $5(2) \mathrm{Ca}$

penultimum, $5(2) \mathrm{Cc}$

Panartus

tetrathalamus, $5(2) \mathrm{Cd}$

Periphaena

decora, 5(3)Ba; P1. 1C, figs. 1-6; P1. 2A, fig. 3, Tab. 1, 2, 5

delta, 5(3)Bb; P1. 1C, fig. 7, Tab. 2, 5

dupla, 5(3)Ba

tripyramis triangula, 5(3)Bd, Pl. 1D, figs. 1, 2, Tab. 1, 2, 5

tripyramis tripyramis, 5(3)Bc; PL. 1C, fig. 8, Tab. 2

Petalospyris

ateuchus, 5(6)Aa

triceros, 5(6)Ba, Pl. 2B, figs. 5, 6, Tab. 1, 2, 5

Phacotriactis triangula, 5(3) Bd

Phormocyrtis

embolum, 5(7)La; Pl. 1H, figs. 4, 5, Tab. 1, 2, 5

striata striata, $\mathbf{5 ( 7 ) L b , ~ P l . ~ 1 F , ~ f i g s . ~ 1 5 - 1 8 , ~ T a b . ~ 1 , ~ 2 , ~} 5$

Phormostichoartus

corona, 5(9)Ba; PI. 7, fig. 7, Tab. 3, 4

Pipetella

prismatica, 5(2)Ac

Podocyrtis

ampla ampla, $2 ; 3 ; 5(8) \mathrm{Ba}$

ampla fasciolata, $2 ; 3 ; 5(8) \mathrm{Ba}$, Pl. 1K, figs. 1, 2; Pl. 4, figs. 2, 3, Tab. 1, 5

aphorma, 5(8)Bc; Pl. 1K, figs. 11, 12, Tab. 2

argulus, $5(7) \mathrm{Rb}$

chalara, 2

diamesa, 5(8)Bc; 5(8)Bb; PI. 1K, figs. 3-5, Tab. 1, 2

dorus, 5(8)Bc; Pl. 1K, fig. 6, Tab. 1, 2, 5

goetheana, 2

helenae, 5(8)Bf; Pl. 1L, figs. 9-11; Pl. 4, figs. 4, 5, Tab. 1, 5

hirsutus, $5(7) \mathrm{Rb}$

mitra, $2 ; 3 ; 4 ; 5(8) B g ;$ PI. 1L, figs. 5, 6, Tab. 1, 5

papalis, 5(8)Bd; Pl. 1K, figs. 7-10, Tab. 1, 2, 5

sinuosa, 5(8)Bf; 5(8)Bh; Pl. 1L, figs. 1-4, Tab. 1, 2, 5

tetracantha, 5(7)Rf

trachodes, 5(8)Bi; PI. 1L, figs. 7, 8, Tab. 1, 5

triacantha, 5(7) Rg

Pterocanium

prismatium, $2 ; 3 ; 5(7) \mathrm{Ma}$, Tab. 3

Rhopalocanium

ornatum, $5(7) \mathrm{Na}$, Pl. 1H, figs. $6-10$, Tab. 1, 2, 5

Sethochytris

babylonis, $5(7) \mathrm{Kb}$

Solenosphaera

omnitubus, 3; 5(1)Aa; PI. 5, fig. 1, Tab. 3, 4

Spongaster

berminghami, 5(5)Da; PI. 6, fig. 4, Tab. 3, 4

aff. berminghami, 5(5)Db; PI. 6, fig. 5, Tab. 3

klingi, 5(5)Da, Tab. 4

pentas, 3; 5(5)Dc; P1. 7, fig. 1, Tab. 3, 4

tetras irregularis, 5(5)Dd

tetras tetras, 3; 5(5)Dd; PI. 7, fig. 2, Tab. 3, 4

Spongasteriscus

cruciferus, 5(5)Ea

Spongatractus, 5(2)D

balbis, 5(2)Da; PL. 1A, figs. 6, 7, Tab. 2

pachystylus, 5(2)Db, Pl. 1A, figs. 8-11, Tab. 1, 2, 5

Spongodiscus

cruciferus, 5(5)Ea

aff. cruciferus, 5(5)Ea, P1. 3, fig. 3, Tab. 2, 5 phrix, 5(5)Eb, P1. 1D, figs. 8, 9, Tab. 2, 5

pulcher, $5(5) \mathrm{Eb}$

rhabdostylus, 5(5)Ec, Pl. 1E, figs. 1-3, Tab. 2

Spongosphaera, 5(2)D

pachystyla, $5(2) \mathrm{Db}$

pachystylus, $5(2) \mathrm{D}$

polycantha, 5(2)D

rhabdostyla, 5(5)Ec

Stichocorys

delmontensis, 3; 4; 5(7)Oa; P1. 7, fig. 4, Tab. 3, 4

peregrina, $3 ; 4 ; 5$ (7)Ob; Pl. 7, fig. 5 , Tab. 3, 4

Stylatractus

neptunus, 5(2)Ea

Stylocyclia dimidiata, 5(4)Ad

Stylosphaera

coronata, $5(2) \mathrm{Ea}$

coronata coronata, 5(2)Ea, PI. 1B, figs. 1-3, Tab. 1, 2

coronata sabaca, 5(2)Eb, Pl. 1B, fig. 4, Tab. 2, 5

hispida, 5(2)Ea

Stylotrochus

quadribrachiatus multibrachiatus, 5(5)Fb, Pl. 3, fig. 5, Tab. 2 quadribrachiatus quadribrachiatus, $5(5) \mathrm{Fa}, \mathrm{Pl}$. 1E, fig. 4,

Tab. 1, 2, 5

Theocampe

amphora group, 5(9)Ca; Pl. 1M, figs. 1-5; Pl. 2E, fig. 7,

Tab. 1, 2, 5

armadillo group, 5(9)Cb; Pl. 1M, fig. 6; Pl. 2E, fig. 8, Tab. 1, 2, 5 collaris, 5(9)Ba

eos, 5(9)Ca

excellens, $5(9) \mathrm{Ca}$

mongolfieri, 3; 4; 5(9)Cc; Pl. 1M, figs. 7-10; Pl. 2E, fig. 9,

Tab. $1,2,5$

pirum, 4; 5(9)Cd; Pl. 2E, fig. 10, Tab. 2, 5

urceolus, $5(9) \mathrm{Ca}$

Theocamptra

corona, 5(9)Ba

Theocorys

anapographa, 5(7)Pa, Pl. 1H, fig. 11, Tab. 2, 5

sp., 5(7)Qc

(?) spongoconum, 4; 5(7)Pb, Pl. 2D, fig. 5, Tab. 2, 5

spongoconus, $5(7) \mathrm{Pb}$

Theocotyle

cryptocephala (?) conica, 4; 5(7)Qa; PI. 1I, fig. 4, Tab. 1, 2, 5 cryptocephala cryptocephala (?), 4; 5(7)Qb; P1. 1I, figs. 2, 3,

Tab. 2, 5

cryptocephala (?) nigriniae, 5(7)Qc; P1. 1I, fig. 1, Tab. 2, 5

ficus, 5(7)Qd, P1. 1I, figs. 5-8, Tab. 1, 2, 5

Theocyrtis

annosa, 2;

tuberosa, $2 ; 3 ; 4 ; 5(8)$ Ca; PI. 2E, figs. 4, 5, Tab. 1, 2, 5

Thyrsocyrtis

bromia, 1; 2; 3; 5(7)Ra; Pl. 2D, fig. 6, Tab. 1, 2, 5

hirsuta hirsuta, 5(7)Rd; 5(7)Rb; P1. 1J, fig. 1, Tab. 2, 5

hirsuta robusta, 5(7)Rc; PI. 1J, fig. 2, Tab. 2, 5

hirsuta tensa, 5(7)Rd; PI. 1J, figs. 3, 4, Tab. 2, 5

jacchia, 5(7)Ja

rhizodon, 5(7)Re; PI. 1I, figs. 9-13; PI. 2D, fig. 7, Tab. 1, 2, 5

tetracantha, 2; 5(7)Rf; PI. 2E, fig. 2, Tab. 1, 2, 5

triacantha, 3; 5(7)Rg; PI. 1J, figs. 5-7; PI. 2E, fig. 1, Tab. 1, 2, 5

Triactis

tripyramis, 5(3)Bc

tripyramis triangula, $5(3) \mathrm{Bd}$

tripyramis tripyramis, 5(3)Bc

Trigonactura

angusta, 5(4)Aa

Trigonastrum

sp 5(5)Bb

Tristylospyris

triceros, $5(6) \mathrm{Ba}$, Tab. 5 